Portland State University

PDXScholar

Fall 1-10-2014

\title{
A Study of Small Talk Among Males: Comparing the U.S. and Japan
}

Chie Furukawa

Portland State University

Follow this and additional works at: https://pdxscholar.library.pdx.edu/open_access_etds

Part of the Gender, Race, Sexuality, and Ethnicity in Communication Commons, Japanese Studies Commons, and the Speech and Rhetorical Studies Commons Let us know how access to this document benefits you.

\section{Recommended Citation}

Furukawa, Chie, "A Study of Small Talk Among Males: Comparing the U.S. and Japan" (2014). Dissertations and Theses. Paper 1522.

https://doi.org/10.15760/etd.1521

This Thesis is brought to you for free and open access. It has been accepted for inclusion in Dissertations and Theses by an authorized administrator of PDXScholar. Please contact us if we can make this document more accessible: pdxscholar@pdx.edu. 
A Study of Small Talk Among Males: Comparing the U.S. and Japan

$$
\text { by }
$$

Chie Furukawa

A thesis submitted in partial fulfillment of the requirements for the degree of

\author{
Master of Arts \\ in \\ Japanese
}

Thesis Committee:

Suwako Watanabe, Chair

Emiko Konomi

Patricia J. Wetzel

Portland State University

2013 


\begin{abstract}
This study seeks to understand the social interaction of small talk in two different countries. Defining small talk as 'phatic communion' and 'social talk' as contrasted to 'core business talk' and 'work-related talk,' Holmes (2000) claims that small talk in the workplace is intertwined with main work-talk. Small talk can help build solidarity and rapport, as well as maintain good relationships between workers. Much of the research on small talk has been focused on institutional settings such as business and service interactions; thus, there is a need for research on non-institutional small talk between participants without established relationships.

This study compared how native English and Japanese male speakers interact in small talk that occurs during the initial phase of relationship formation, when interlocutors who have just met are waiting for a shared purpose. I analyzed their unmonitored small talk interaction in order to examine what types of topics they discuss and how conversations actually occur. I also conducted interviews to obtain information on perceptions of small talk and examined how these perceptions reflect different social norms and values pertaining to small talk in real-life settings. The data on the characteristics of small talk come from the pre-interview conversation between two participants, and the data on perceptions about small talk come from the interviews.

The topics discussed differed between the U.S. and Japanese pairs. The U.S. pairs had "Informational Talk" elaborating on class details such as professors, systems, materials, or class content. The Japanese pairs, on the other hand, had "Personal Informational Talk," talking about personal matters such as study problems, worries, gossip, and stories. Furthermore, the Japanese pairs tended to have many pauses/silences
\end{abstract}


compared to their English-speaking counterparts (the average frequency of pauses per conversation were 6 for the U.S. participants and 16 for the Japanese), presenting the impression that the Japanese pairs might have been uncomfortable and awkward. However, one similarity was that both groups discussed topics on which they shared knowledge or discussed the research study in which they were participating in order to fill silence during small talk with strangers.

The most prominent result from the interviews is that interactions with strangers are completely normal for the U.S. participants, while for the Japanese participants such small talk with strangers makes them feel surprised and uncomfortable. The U.S. participants have numerous experiences with and are aware of the small talk occurring in everyday life, and they commonly discuss impersonal subjects; that is, their talks tend to be about factual information. The Japanese males, on the other hand, reported that they do not commonly talk with strangers; they need a defined place or reason to talk in order to converse openly and exchange personal information. However, in the actual preinterview small talk, they incrementally came to know each other and started to discuss personal concerns and gossip about friends. This study has shown that small talk can be viewed as a locus where cultural differences in social norms are reflected. 


\section{DEDICATION}

I dedicate this thesis to my family, especially...

to my brother Yuto Furukawa, for instilling in me the importance of hard work;

to my sister Risa Furukawa, for her encouragement and thoughtful spirit;

to my parents, Masanori and Ruriko Furukawa, for their endless love and support. 


\section{ACKNOWLEDGEMENTS}

I would like to express my deepest appreciation and thanks to the following people:

My thesis advisor, Dr. Suwako Watanabe, for her patience, warm support, and empathy in guiding me through an completing of this project. She always made time for me and guided me to the next step with her pertinent comments. Without her guidance and encouragement, I could not have completed this project.

I would like to express my sincere gratitude to Dr. Emiko Konomi. Her outstanding teaching style and her charismatic personality taught me about not only effective teaching Japanese language but also the way how to excel at managing and supervising people. Her memorable phrases and energy have allowed me to succeed and prepared me for the future.

I would like to thank Dr. Patricia. J. Wetzel who allowed me to study at PSU. She was truly my first introduction to the field of sociolinguistics and Japanese language; her classes, lectures and dedication to the field inspired me and opened my eyes to understanding of language. She also has been willing to listen to my ideas about language and culture both professional and personal.

Furthermore, I would like to thank Thomas Mason Jr. for allowing me to participate in the ALLEX program and giving me the opportunity to challenge myself here in the U.S. in 2008. I became the person I am today because he gave me the chance to be a Japanese language instructor in the U.S. His expectations for me prepared me for the future. Dr. Eiko Torii Williams in Wellesley College taught me to teach Japanese 
language and guided me in my masters degree. Without her endless support, I could not survive in the U.S. I would like to thank Norman Arthur Chaput for his help with my writing, his thoughtful advice through the whole process and for his warm support and devoting his precious time. Satomi Hayashi and Nao Okumura have given me help and comments on my research; their friendship was invaluable and helped me to get through some of the tough times.

Finally, my truthful appreciation to all the English speaking and Japanese men who took time out of their busy schedules and contribute to my research goal; without their voices and their linguistic practice, this project would not have been possible. I am blessed to have been surrounded by loving friends and supportive professors while writing my thesis. To all of you, I would like to give my deepest thanks. 


\section{TABLE OF CONTENTS}

ABSTRACT

. $\mathrm{i}$

DEDICATION

ACKNOWLEDGEMENTS ........................................................

LIST OF TABLES ....................................................................

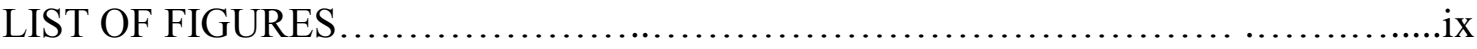

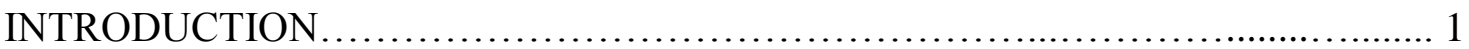

CHAPTER 1: LITERATURE

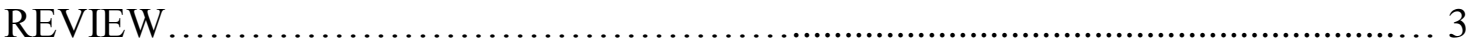

1.1. Research on Small Talk

1.2. Characteristics of Cross-Cultural Communication

1.3. Characteristics of Japanese Gendered Talk

CHAPTER 2: RESEARCH METHODS ....................................... 24

2.1. Research Design

2.2. Participants

2.3. Data Collection Procedure

2.4. Analytical Procedure for Small Talk Phase

2.4.1. Topics

2.4.2. How Participants Use Pause or Silence

2.4.3. Loop Sequences in Small Talk

2.5. Analytical Procedure for the Interview

CHAPTER 3: ANALYSIS

3.1. The Unmonitored Pre-Interview Conversation

3.1.1. Topics Participants Discussed

3.1.2. How Participants Use the Pause or Silence

3.1.3. Loop Sequences in Small Talk

3.2. The Interview

3.2.1. Setting for Small Talk

3.2.2. The Types of Topics Participants Discussed (Off-Campus)

3.2.3. Why Do Participants Talk to Strangers? How Do They Feel About It? 
3.2.4. Differences in Attitude and Stance for Different Types of Interlocutor

3.2.5. Do Conversations With Strangers Happen Often?

CHAPTER 4: DISCUSSION................................................. 62

4.1. The Unmonitored Pre-Interview Conversation

4.1.1. Topic Participants Discussed

4.1.2. How Participants Use the Pause or Silence

4.1.3. Loop Sequences in Small Talk

4.1.4. Noncommittal Remarks

4.2. The Interview

4.2.1. Different Views on Small Talk

4.2.2. Similar Views on Small Talk

4.2.3. The Japanese Participant's Views on Small

4.2.4. Japanese Small Talk Sometimes Happens

4.3. Limited Data Collection

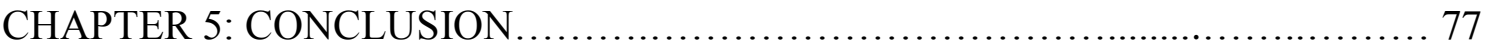

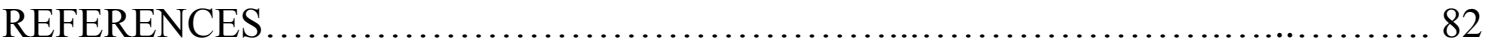

APPENDICES

A. INFORMED CONSENT FORM........................................... 86

B. INFORMATION SURVEY QUESTIONNAIRE.......................... 87

C. JAPANESE INFORMATION SURVEY QUESTIONNAIRE.................... 88

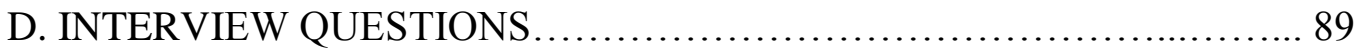

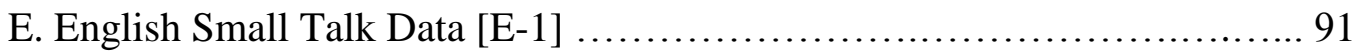

F. English Small Talk Data [E-2] ........................................ 96

G. English Small Talk Data [E-3] ....................................... 100

H. Japanese Small Talk Data [J-1] ........................................... 106

I. Japanese Small Talk Data [J-2] .......................................... 112

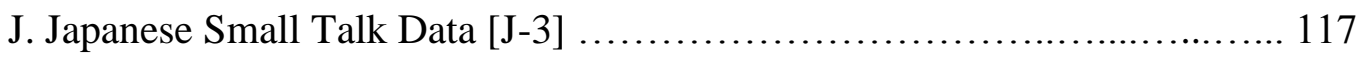

K. Japanese Small Talk Data [J-4] ......................................... 125 


\section{LIST OF TABLES}

TABLE A

The Three Situational Domains (Lebra, 1976, p.112)................................... 11

TABLE B

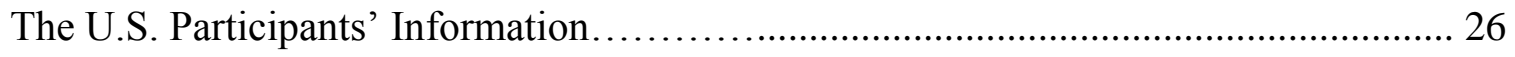

TABLE C

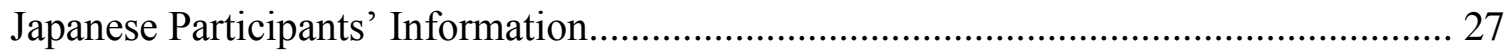

TABLE D

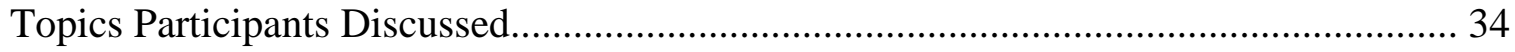

TABLE E

Time/Length of Topics the U.S. and Japanese Participants (in seconds) ...................... 36

TABLE F

Examination of Pauses Longer than Three Seconds for the U.S. and Japanese Pairs (in

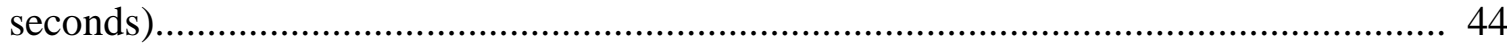

TABLE G

Initial Remarks Following Silence for U.S. and Japanese pairs................................ 47

TABLE H

Frequency of Loop-Sequence for English and Japanese Pairs................................... 48

TABLE I

Varieties of Noncommittal Remarks.................................................... 52

TABLE J

Place of Small Talk in the U.S. and Japanese Participants ................................... 55 


\section{LIST OF FIGURES}

FIGURE 1

Criteria for Distinguishing Business Talk From Phatic Communion

(Holmes, 2000, .37) ...........................................................

FIGURE 2

Locating Small Talk on the Continuum (Coupland, 2000, p.38).......................6 


\section{INTRODUCTION}

Pullin (2010) states that of all forms of interpersonal communication, so-called "small talk" is one of the best at promoting rapport and good relationships between workers (p.456). Small talk can help build solidarity and rapport. Rapport is one of the most important elements in the building and maintenance of strong working relations (Pullin, 2010, p.456). Rapport has been studied by many researchers in both the linguistics and management fields. Pullin (2010) also mentions that "the value of small talk derived from such common ground can be not only in creating solidarity, but also in creating bonds between different others" (p.465). Small talk is a valuable activity in the business world as well as in personal life. Without it, our interpersonal relationships would be less stable.

Researchers in the field of linguistics discuss the difference between institutional talk and ordinary talk. While small talk in the U.S. has been examined in institutional settings like service encounters, doctor-patient interaction, professional counseling, and work meeting (Iacpbucci1990; Drew and Heritage 1992; Holmes 2003; Yamada 1997), and to some extent has been examined in ordinary talk, there is still a need to study small talk that occurs in non-institutional settings. In addition, the literature lacks a good comparison of how small talk is conducted in different cultures. In this thesis, I present a study that I conducted to compare small talk between males in the US and Japan.

In this first chapter I present reviews of the literature related to small talk, characteristics of U.S.-Japan cross-cultural communication, and characteristics of gendered talk in the U.S. and Japan. In the second chapter, I show how I conducted my 
research into small talk, and explain my data collection and analytical procedures. The third and fourth chapters contain analyses of small talk and a discussion of my findings, which will be followed by the final conclusion in the last chapter. 


\section{CHAPTER 1: LITERATURE REVIEW}

\subsection{Research on Small Talk}

Small talk is not well defined in the literature. Schneider (1988:4) says, "If the term has been used in linguistics at all, it is not strictly defined, relying on the intuitive notion of language users instead" (p.4). Researchers, however, discuss the characteristics of small talk. Coupland (2000:1) refers to Robinsons' definitions of small talk: “...supposedly minor, informal, unimportant and non-serious modes of talk," meaning that small talk is conversation about insignificant matters, not as important or essential as practical talk like that between doctors and patients or professors and students. Similarly, Robinson characterizes small talk as a "peripheral mode of talk" (cited Coupland, 2003, p.1), and provides examples of it such as 'gossip,' 'chit chat,' and 'time-out talk.' A first glance at the characteristics of 'small talk' may imply that small talk is unimportant and trivial. However, small talk lubricates social interaction. According to Long's dictionary, (1979) small talk is "polite conversation about unimportant matters, esp. at social gatherings" (cited Schneider 1988). Therefore, small talk has a social function even though the content of the talk may not be vital.

Small talk is described as "zatsudan" by Japanese language researchers (Ohama; 1995, Matsuda; 1998, Ri; 2000). According to Furuta's Obunsha Japanese Dictionary, (1991) zatsudan is "toritomeno naikoto o kimamani hanasukoto, mata sono hanasi [to talk about a rambling story indulgently, and that story]" (Furuta, 1991, p.369). The characterization of zatsudan as toritomenonai [rambling, pointless, wondering, go- 
nowhere, discursive, meandering and so on] aligns with the features of small talk pointed out by the non-Japanese researchers. However, the zatsudan studied by previous researchers was restricted to that held between sisters, friends, or teachers and mothers. In other words, zatsudan interlocutors are in close relationships; there seems to be little research on zatsudan between strangers. Furthermore, to my knowledge, no Japanese researchers have properly investigated small talk, as occurring in the U.S., between Japanese speaking strangers, or explained that "small talk" is not exactly analogous with zatsudan. Based on the characterization of "small talk" found in the literature, I have crafted my own definition as follows:

Small talk is a sociolinguistic term referring to informal talk whose main purpose is mere socialization without a practical purpose. Small talk frequently happens in everyday life as well as during transactional interactions. It may happen between anyone; friends, family members, colleagues, acquaintances, teachers and students, customers and cashiers, and strangers. The function of and conventions about small talk vary by culture.

Previous research shows that small talk can occur within transactional or institutional talk as well as within everyday conversation.

Blum-Kulka (2000) studies differences in a family dinner conversation between Israelis and Jewish-Americans. Her study shows the variety of information that gossip represents, especially “... sociable talk, with important socializing gains for children" (p.238). Small talk also occurs during telephone exchanges. Drew and Chilton (2000) study close friends' and families' telephone calls. They investigate the patterns of call openings, or the first topics discussed. They argue that habitual calling between mother and daughter, close friends or acquaintances implies 'keep[ing] in touch', and is not 
calling for any specific purpose. They also claim that keeping in touch can be the main content for the talk.

Coupland and others (2003) have shown that small talk at work helps to build rapport among workers and create solidarity-oriented functions in the workplace; small talk also can build rapport even in transactional relationships, such as that between lawyers/counselors and patients/clients, or between cashiers and customers (Coupland, 2003). Coupland and others utilized Malinowski's concept of "phatic communion," as "the earliest and the prototypical formulation of small talk as a communicative mode (p.2).” Malinowski (1972) mentions it as "language used in free, aimless, social intercourse" (p.149). He states that phatic communion is "a type of speech in which ties of union are created by a mere exchange of words" (p.151).

Holmes distinguishes business talk from phatic communion. Figure 1 shows that while core business talk is relevant "on-topic" talk, maximally informative, contextbound and transactional, phatic communion is atopical talk, minimally informative, context free and social (Holmes, 2000, p.37).

\begin{tabular}{|c|c|}
\hline Relevant 'on-topic' talk & Atopical talk \\
\hline Maximally informative & Minimally informative \\
\hline Context-bound & Context-free \\
\hline Transactional & Social \\
\hline
\end{tabular}

Figure 1: Criteria for Distinguishing Business Talk From Phatic Communion (Holmes, 2000, p.37)

Furthermore, Holmes (2000) argues that "Small talk is one means by which we negotiate interpersonal relationships, a crucial function of talk with significant 
implications for on-going and future interactions" (p.34). Small talk in the workplace is intertwined with main work-talk. Holmes' (2000) figure divides the location of small talk in the workplace into four main themes: 'core business talk,' 'work-related talk,' 'social talk' and 'phatic communion' (p.38).

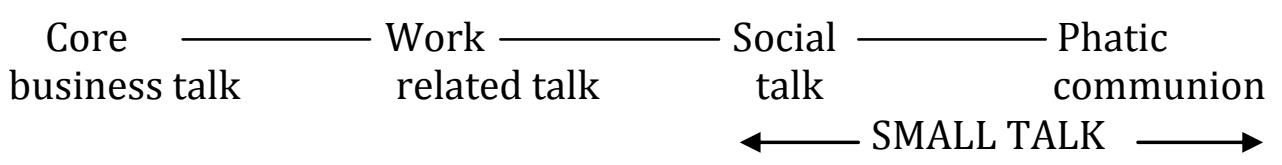

Figure 2: Locating Small Talk on the Continuum (Holmes, 2000, p.38)

Holmes mentions that conversation often switches between small talk and practical talk (Holmes, 2000, p.40). The following excerpt is from Holmes study on small talk:

Context: Two office workers at the beginning of the day

$1 \mathrm{C}$ : I went to Nelson over the holidays you know

$2 \mathrm{~N}$ : oh this holiday?

$3 \mathrm{C}: \mathrm{mm}$

4 N: oh okay

$5 \mathrm{C}$ : first time for +well to have a look around

Holmes explains that the workers discussed holiday locations for four minutes, and then moved on to 'core business talk.' This conversation about holiday locations is 'social talk,' according to Holmes. In contrast, an example of 'phatic talk' is two workers having an off-topic conversation with a personal component (p.40). 'Core business talk' is between people who have a situational reason to talk; they discuss 'work-related topics.' Small talk falls under 'social talk' and 'phatic communion' (p.40).

Small talk occurring in an institutional setting can be defined as a verbal interaction which contributes to the main goal of a relationship—-for instance a boss chatting about office events before or after discussing the main work-related topics, or a 
doctor and patient talking about themselves before, during or after a session of discussing medical issues.

Researchers distinguished non-institutional talk from institutional talk; however, small talk in an institutional setting is fluid, and has traits similar to both non-institutional small talk, and institutional talk. It may be beneficial to study small talk in noninstitutional setting in order to research focus on small talk. Furthermore, there seems to be little research on the first formation of interaction in non-institutional settings, such as when participants interact or meet for the first time. Previous researcher such as BlumKulka's (2000) study of family members having dinner, and Drew and Chilton (2000) with their friends talking on the phone, have examined small talk in everyday conversation. However, their participants are familiar with one another; very few studies have studied small talk between strangers. This study attempts to answer the question of how two strangers engage themselves in small talk in a non-institutional setting.

\subsection{Characteristics of Cross-Cultural Communication}

According to Gumperz (1982), ways of signaling intentions and meanings and ways of constituting the context of communication are not universal but instead are culturally relative (p.162). When people are faced with unexpected interactions, they may feel offended or merely be at a loss, not knowing how to respond (for instance, when Japanese people are asked, "How are you?" in a service encounter). Bailey’s study (2009) of service encounters between immigrant Korean business owners and African American customers is a case in point. Immigrant Koreans interact only with a greeting or servicerelated exchange (socially minimal exchange), while African-Americans tend to be enthusiastic about personal interaction in service encounters (socially expanded 
exchange). They have, Bailey states, different ideas about how to communicate respect in service encounters. Similarly, Japanese people are not used to talking about personal matters during a service encounter, so they may experience discomfort. Simultaneously, English cashiers may be offended by Japanese customers' brevity, or find them to be rude. Different ideas of politeness also can be seen in the everyday interactions.

Katsuta's (2012) study shows the differences between Japanese and Americans when engaging in compliment response in a casual setting. She found that compliment response differs between the two cultures depending on the topic of the compliment (Appearance, Characteristic, Ability, Achievement or Belongings). Her research illustrates that Americans tend to accept compliments more often than Japanese, and Japanese tend to avoid and reject compliments more often than Americans (Katsuta, 2012, p.74). When Japanese people are complimented on their appearance or belongings, they usually respond with humility, which is often cited as one of the characteristics of Japanese culture. For example, Japanese might reply to a compliment about appearance by saying, "No, I am not [pretty]," instead of by saying "Thank you." However, these kinds of comments sometimes upset non-Japanese people, and make them uncomfortable with the Japanese response. Non-Japanese people may have difficulty understanding the humble Japanese manner, and vise-versa. She concludes that the two socio-cultural groups have different ideas of politeness, and appropriate manners are defined differently in each culture.

Brown and Levinson's $(1978,1987)$ describe politeness by using the notion of "face." They define face in terms of "want": "negative face (the want of every 'competent adult member' that his actions be unimpeded by others)," and "positive face 
(the want of every member that his wants be desirable to at least some others)" (p.62). Matsumoto (1988) refers to Brown and Levinson's "face," and claims that " politeness is a form of social behavior, 'face' defined as one's 'socially given self image' is plausibly a useful notion in explaining a universal motivation for politeness" (p.423). Many researchers point out that Japanese society is mainly characterized by negative politeness (Matsumoto, 1988; Nakane 2006). For instance, in Japanese, when receiving gifts from others, the receiver often says "Okizukai itadaite, sumimasen [Lit: Thank you. I am sorry to have you take this trouble for me]," (JSL 18A p.139). Japanese people do not say just 'Thank you'; instead they apologize when receiving a gift, because they feel bad about the gift-giver's trouble on the receiver's behalf. In this situation, the Japanese used an apology to show their empathy (omoiyari); therefore, "I am sorry to have you take this trouble for me" implies 'you went to buy the gift for me,' 'you spent lots of time and money,' and 'you cared about me.' This is an example of how Japanese culture is characterized by negative politeness. Similarly, if the receiver said "Arigatoo gozaimasu, totemo uresii desu [Thank you, I am very happy]," this politeness would be positive politeness. As the above example demonstrates, Japanese interaction is substantially oriented toward negative politeness rather than positive politeness. This sheds some light on the Japanese cultural concept of "wa", or group harmony (Lebra, 1976; Nakane, 1970; Watanabe, 1993). Researchers have shown that, with respect to this $w a$, Japanese people assign the highest priority to their relative position or hierarchical relationship with others. Matsumoto (1988) points out that in Japanese culture "people are expected to act properly according to their relative position or rank with regard to other members of the group, and it is that relative position that they want to maintain" (p.243). Additionally, 
the Japanese social framework is strongly influenced by hierarchy, and this can be crucial to understanding Japanese communication styles.

Watanabe (1993) compares interactions in a group discussion between Japanese and American students and argues that hierarchical relationships are an indispensable part of proper Japanese interaction. She discovers that it took the Japanese groups a long time to start their discussion because they first had to decide who would initiate the conversation and in what order it would proceed. In the American groups, on the other hand, one of the participants voluntarily initiated the discussion. Furthermore, Watanabe illustrates that the Japanese participants in her study perceived themselves to be members of a group during the discussion (p.204). A vertical relationship guided the interaction in the Japanese discussion. The leader (the oldest male) directed the discussion, and consulted with other members about how and when to end the discussion. The leaders sought to confirm that all participants in the discussion group shared the same experience, and felt similarly about the ending of the discussion. This style shows that Japanese communication relies on hierarchical relationships in order to maintain " $w a$," or group harmony. Watanabe describes this by saying, "In order to act properly, a Japanese must be deliberate, determining hierarchy within a given situation and acting as a member of a group within which hierarchical order governs its members" (Watanabe, 1993, p.191). Without hierarchical order, Japanese communication cannot be achieved smoothly. Japanese communication is united based on a hierarchy which helps maintain wa in a given situation; therefore, Japanese people are sensitive to where they belong or where they are, and they are able to adjust or be ready for situational changes (Lebra, 1976, p.111). 
Although situational awareness may be a universal trait, Japanese people seem to be particularly aware of their conversational surroundings. It may be no exaggeration to say that Japanese people decide their behavior and conversation topics situationally; their behavior is determined by where they are and who they are with.

Table A: The Three Situational Domains (Lebra, 1976, p.112)

\begin{tabular}{|l|c|c|}
\hline & omote ("front") & ura ("back") \\
\hline uchi ("in") & --- & Intimate \\
\hline soto ("out") & Ritual & Anomic \\
\hline
\end{tabular}

Lebra (1976) classifies situations for Japanese interaction into three spheres by using the dichotomy of "uchi" (in) and "soto" (out) on one axis, and the dichotomy of "omote" (front: what is exposed to public attention) and "ura" (back: what is hidden from the public eye) on the other. As depicted in Table A, "Intimate" situations are both uchi and ura, while "Ritual" situations are soto and omote and "Anomic" situations are ura and soto (p.112). Furthermore, uchi is private, while soto is public. Lebra writes Japanese people "...vary their behavior in accordance with" the situational domain (p.114). In other words, situations can change from intimate to anomic, ritual can change to intimate, and anomic situations can change to ritual or intimate. Lebra also mentions that ritual behavior relates to status orientation, which she described as " ...the ritual actor concern[ing] himself with conforming to conventional rules, manners, and etiquette, present[ing] himself with his social mask on, and manage[ing] his impression on Alter or a third-person witness" (p.121). Lebra explains that ritual behavior in a ritual situation 
(soto and omote) would be characterized by the people following ideal social

expectations and familiar conventions, and examples are service encounters or interaction with strangers in public. Intimate situations (uchi and ura) are a confirmation of unity, of shared experiences with those nearby, for example when hanging out with friends, having lunch with classmates, or drinking at a bar with friends.

Touching, slapping, and passing are some examples on intimate interaction between friends (Lebra, p.115). However, friends can take this mischief too far, changing the situation from intimate to anomic. Similarly, such situations can change from intimate to ritual if, for example, a new member is introduced to the group. Anomic situations are unfamiliar, novel, and often public, and do not require that the participant/s maintain omote (that which is exposed to the public). According to Lebra, in anomic situations Japanese people can afford to be rude or shameless. Lebra also mentions that anomic behavior is a basic human behavior, shared in all cultures (p.132). This does not mean, however, that all cultures have the same definition of anomic situations or the line between anomic and others situational domains--compared to people in the U.S., Japanese people have clear-cut definitions of intimate and ritual situations, and are likely to tightly regulate their behavior to adapt to the situation (p.132).

Whereas the notion of private vs. public may be readily understood in Western cultures, the combined notion of omote and ura is vital to understanding the Japanese communication style. Omote and ura can also be called "tatemae" (what one says on the surface; the standards, principles, or rules by which one is bound (at least outwardly)), and "honne" (one's natural, real, or inner wishes and proclivities). Because of the need to maintain social harmony, at least on the surface level, Japanese carefully use tatemae and 
honne. Japanese people employ tatemae and honne in order to counter the social pressures, to avoid conflict, and to conform to conventional rules; therefore, there may be a difference between spoken words and actual intentions. This may be because of the interlocutors' vertical relationship, or because of a desire to maintain harmony through social convention. Omote is the Japanese idea of knowing what is supposed to be done or what may be allowed in the public, while ura is what is veiled from the public, or what a person is really thinking. Showing ura in public is sometimes considered wrong or immature in Japanese society. For instance, when Japanese talk publicly in ritual situations (soto and omote) such as service encounters or on public transportation, the interactions often have a prescribed exchange which does not allow much deviation, but when it is deviated, there may be a social consequence. And soto (public) -ura (back) situations can be anomic, such as when a Japanese visitor in the U.S. is confused by the "How are you?" question in service encounters. (However, these situations can quickly become intimate, if the customer knows the cashier or if the customer and cashier discover that they have a mutual friend). When viewed through the lens of Lebra's three situational domains, the setting for the small talk in this study is a ritual situation, which occurs when omote (the Japanese idea of knowing what is supposed to be done) and soto (that which is public-and interacting with people of less familiarity) are combined. However, how conversation actually occurs in small talk is unknown, especially how the situation changes (whether it changes to intimate, anomic or stays ritual). Lebra's idea of situational domains in Japanese behavior helps understand how small talk actually occurs in Japanese conversation. 
An understanding of Lebra's situational domains informs our interpretation of Barnlund's concept of "self" (1975). Barnlund (1975) shows that interpersonal communication styles differ between Japanese and English speakers because each group has differing concepts of "self." The data for his study came from examination of the several instruments to assess the communicative styles of Japanese and Americans: a Role Description Checklist, a Self Disclosure Scale, a Nonverbal Inventory, and a Defensive Strategy Scale (p.44). This battery of questionnaires was administered between 1968 and 1972 to 240 participants whose ages ranged from 18 to 24 . Half were Japanese, half American, and each group was evenly divided by gender. The goal of the research was to find out "to whom Japanese and Americans talk, what they talk about, how much they disclose of themselves, what kind of nonverbal contact they maintain, and how they defend themselves against threatening remarks" (Barnlund, 1975, p.44).

Based on the result of this research, Barnlund divides "self" into "Public Self" and "Private Self." He defines public self as that which "identifies aspects of the person that are readily available and easily shared with others," and private self as that which "marks off aspects of the person that are potentially communicable, but are not often or not usually shared with others" (Barnlund, 1975, p32-33). One of Barnlund's conclusions is that Japanese "[usually] interact more selectively and with fewer persons" while Americans, "[usually] communicate with a larger number of persons and less selectively" (Barnlund, 1975, p34-36). In other words, Japanese and American conversational styles differ depending on number and type of interlocutors. Americans may take more opportunities to talk with strangers in daily life, while Japanese are less likely to do so. Furthermore, Barnlund finds that, in terms of values, "the Japanese, across a variety of 
topics, should communicate less of themselves verbally and prefer a lower degree of personal involvement (p.35)," while "the Americans should communicate their views more fully and on a more personal level across a variety of topics" (Barnlund,1975, p.38). What can be drawn from this observation is that Japanese and English speakers may have different concept of small talk, such as what topics and degree of personal involvement are appropriate. I intend to use the notions of public and private self as well as Lebra's situational domains to study how English speakers and Japanese talk with strangers at first contact, what they talk about, and how they initiate and conduct small talk.

According to Malinowski (1923), one of the main goals of social performers engaging in phatic talk (small talk) is the avoidance of silence (cited in Coupland, 2000). Silence is important in all communication, but previous researchers have shown that the use of silence and toleration of silences differs depending on culture. There are significant differences in the usage of and level of toleration for silence between Englishspeakers and Japanese (Yamada, 1997; Nakane, 2006; Roberts, Margutti, \& Takano, 2011).Yamada (1997) found in her study of business meetings that American executives and Japanese section heads used silence differently. She writes that "there was an average rate of 5.15 seconds of silence per minute in the Japanese meeting as compared to .74 in the American..." (p.77). Yamada also mentions that American executives verbally closed off their own topics while the Japanese section heads used silence in order to change topics. The Japanese section heads in her research used eight-second pauses, and sought to confirm during every silence that all members in the meeting shared the same experience and felt similarly about the ending of the meeting or topic during every silence. Nakane (1970) points out that Japanese "prefer silence [over] such words as 'no' 
or 'I disagree.' The avoidance of such open and bald negative expressions is rooted in the fear that it might disrupt the harmony of the group (p.35). Nakane (2006) also studies difference in the use of silence between Australian and Japanese students in classroom situations, and concludes that Japanese students often use silence as a strategy to avoid loss of face (p.1817).

Historical views of Japanese silence and how it differs from silence in the West have been described in art and movies as well as by researchers like Yamada (1992) and Jowaroski (1993). Yamada cites Mizutani’s (1979) research and mentions that, "there are comparative studies that indirectly refer to the American preference for, and the Japanese distrust of, talk (cited in Yamada, 1992, p.36). Mizutani compared a scene from an original Japanese movie and the adapted American western, and he states that he used it “...to illustrate how Americans use talk in a context where Japanese use silence," and that "...for Japanese, silence in context is meaningful and valued" (cited in Yamada, 1992, p.36). Japanese view of silence in arts and movies may be different from that Western culture.

Roberts, Margutti, and Takano, (2011) examine that perception of inter-turn silence across English, Italian and Japanese. They study casual telephone calls between college friends, and focus on gaps arising at the juncture between two persons' turns holding the floor. The participants were asked to listen to dialogues, such as a request where B asks, "Can you give me a ride over there?" and A replies, "Sure," and then to provide their judgments of A's willingness to give her friends a ride as ordinal ratings one through six. Three different silences/gaps were created before A's reply ( 0 ms, 600 $\mathrm{ms}$, and $1200 \mathrm{~ms}$ ). One of their findings is that American, Italian and Japanese 
participants all judged longer silences negatively; however, these three groups orient the inter-turn silence differently (Roberts, Margutti, \&Takano, 2011, p.342). The Japanese participants rated silence as agreeable more often that American or Italian counterparts across all three pause lengths (p.343). Although this study implies that recognition and toleration of silence varies across cultures, how people actually deal with silence in an on-going interaction practice remains a question.

As such, the use and interpretation of silence, just like other communicative interactions, is regulated by different situational features. Basso (1970) states that the form of silence is always the same, but that the functions of silence differ depending on the social context in which it occurs (p.215). Therefore, the interpretation of silence is not always the same in real-life usage. For most interlocutors, a pause in conversation with close friends or significant others is different from silence in conversation with a stranger. A pause or silence in conversation with friends can be just a restrained moment, with no awkwardness or hidden meaning. Jaworski (2000) mentions that “...the contextual factor which affects the meaning of silence is interpersonal distance" (p.117). "Jaworski (2000) notes that, "in certain types of interpersonal relations, most notably intimacy and detachment, silence is common and/or desirable and/or a possible vehicle of phaticity." Therefore, I hypothesize that native English and Japanese speakers in my study will feel uncomfortable with silence that occurs during a small talk setting, and that both American and Japanese participants will feel compelled to talk with each other. In other words, conversation among friends is an informal situation; however, the "small talk" in my research requires a certain degree of formality because the participants are strangers. 
Thus, both groups will experience discomfort with silence while conversing with a stranger.

To the best of my knowledge, not many researchers have studied what happens during silence in non-institutional small talk between strangers, nor have researchers extensively examined the use of silence by Japanese speakers in various communicative events such as small talk, business meetings, and requests. In this study, I compare native English speakers' behavior during pauses in small talk with that of their Japanese counterparts, in hopes of inferring their perception of such pauses.

\subsection{Characteristics of Japanese Gendered Talk}

Tannen (1994) examines the differences between men and women's conversational styles in the workplace and the college classroom. She claims that men and women often misunderstand each other because of their different conversational styles. Men's speaking styles tend to be competitive, while women's styles tend to be harmonious. Tannen's conclusion is that male conversational styles establish a strong position, compete on relative merits, emphasize distinctiveness, take a confrontational position, rely heavily on information, and use direct expressions. Women, on the other hand, tend to have a style that establishes unity, has a great regard for relationships of equals, emphasizes homogeneity, takes a cooperative position, relies heavily on emotion, and uses indirect expressions. Even though men and women speak the same language, they may have significantly different conversational styles.

Many researchers have studied "gendered talk," or the possible differences in syntax and other speech characteristics between men and women. The research is controversial, and some question whether such differences exist. Scholars have identified 
lexical differences resulting from gender, implying a distribution of danseego ("men's language") and joseego ("women's language") (Ide, 1982; Shibamoto, 1985; Ide, 1991; Sturtz-Sreetharan, 2006 and 2009; Saito, 2010). These "languages" are defined by Japanese society, and researchers strove to illuminate and depict the gender differences in the Japanese language. Okamoto and Smith (2004:4) argue that Japanese language has been characterized by a number of stereotypical linguistic features; however, stereotypical linguistic features and the real language as it is practiced are different. They also claim that even though Japanese gendered language is a stereotypical linguistic feature, it includes other of speech styles, such as the polite and honorific forms, sentence-final particles and address terminologies (p.4).

Japanese language and gender research emphasizes the differences in syntax and form for polite speech, or the "honorific" style (Ide, 1982; Ide, 1991). Shibamoto (1985) uses her own and other scholars' research to show the characteristics of Japanese women's language in several linguistic aspects such as phonology, lexicon, pronouns, morphology, syntax, choice of verb ending, and sentence-final particles (p.61). Shibamoto (1985) identifies the different usage of sentence-final particles by women and men, such as "wa" as in "sore de ii wa [that's enough], "ame ga hutte kita wa yo [It has started raining]," and "ze," as in "ore wa moo iku ze [I'm going]" (p.62). Using the particles " $y o$ " and " $n e$ ", she describes usage by both men and women, such as for men men "Iku yo [I'm going]," for women, "Iku wa yo [I'm going]" (p.62). Shibamoto's examples are based on other scholars' studies; her own interview research focused on sentence structure rather than discourse structure. 
Previous researchers have focused on these linguistic aspects, and it may be impossible to generalize about Japanese gendered talk. Generalized male-female language causing conflicts would be seemingly appealing, but this research reminds us to consider the differences between "stereotypical" and "real" language use in a particular situation.

Similar to Okamoto and Smith, Sturtz-Sreetharan (2006 and 2009) and Saito (2011) emphasize the differences between stereotyped and real language. To my knowledge, Sturtz-Sreetharan (2006 and 2009) and Saito (2011) are the only researchers to have published their own work related to Japanese male speech. Sturtz-Sreetharan's (2009) study about Japanese men from Kansai and their use of first- and second-person +pronouns such as ore and omae was particularly illuminating. She emphasizes that the use of pronouns among Japanese males has not been well-informed, and is often contextually governed and fluid. One of her findings is that the usage of boku and ore was significantly different between students and salary men; the students used ore while older speakers used boku, according to her data (p.262). Sturtz-Sreetharan (2006) also studies Japanese usage of clause-final politeness among three different generations (young, middle, and old), and identifies the different speech styles such as honorific, polite, and plain. She used second-order network ties and conducted her research. Once she identified an initial contact person, the male participant was asked to choose two or three men he knows, and then to conduct a recorded conversation in a comfortable place. She found that none of them use the honorific style, although the middle- and old-aged participants use the polite form more frequently than the younger generation (p.77). 
Saito's (2011) study focused on language forms. She (2011) examined Japanese male superior's interaction styles during confrontation in the workplace. She conducted the study in a dental laboratory in Tokyo, where the participants were asked to carry a voice recorder. Saito found that when subordinates challenges were not confrontational, the superiors demonstrated a greater tendency to explain their directives (p.1702). Saito focuses on the linguistic forms such us speech-style: distal-style (desu) and direct-style, verb morau, te morau, or the directive: te kudasai 'please do X (Saito, 2011, p.1700). The Japanese superiors used directive discourse in order to compel obedience, and when subordinates did not challenge their supervisor's directives, the superior's language tended to be empathetic and polite.

While there has been much previous research on the language of Japanese women, relatively little attention has been paid to that of Japanese men.

Wetzel (1988) contrasts the communication strategies of Japanese people and women in the West and claims that the popular view of Japanese interaction is often misleading. Wetzel claims that this popular view creates the misunderstanding that the Japanese communication style is powerless because it resembles that of women in the West. She mentions that cross-cultural miscommunication is similar to cross-gender miscommunication in the West, and that the key to resolving miscommunication is to take into account the notion of power in each country. Wetzel quotes Maltz and Borker (1982), who study male-female communication from an anthropological perspective: "The different sexes acquire different communication styles even as they acquire other behaviors commonly viewed as appropriate to their sex" (cited in Wetzel, 1988, p.556). She states that women and men acquire different cultural rules for interaction. Wetzel 
also shows that there are many similar communication strategies between Japanese people and the characterizations of women's speech in the West, and that the U.S. business community often finds Japanese communication behavior to be puzzling and a challenge. For example, Japanese interaction relies heavily upon demonstrations or signals of empathy, solicitation of agreement, concern about what others are thinking, silent protest as strategy of signaling disagreement or displeasure, and the use of intermediaries (Wetzel, 1988, p.561). Wetzel points out that from the Western point of view, it is easy to conclude that Japanese tend to use language in ways similar to Western women. However, Wetzel's study is not an empirical study of the language use, so it will be meaningful to compare her argument with real language use.

It should be emphasized that my focus is not to generalize gendered talk, nor to seek out gender differences. I will research only male talk because the literature on male talk is sparse, and the two studies (Saito 2011 and Sturtz-Sreetharan 2006) concern subjects who were already familiar with each other (for example, Saito's (2011) five participants had been working at the same company together for at least 12 years). Male talk in institutional settings may differ from male talk in non-institutional settings as well as between those with established relationships and strangers. Moreover, to my knowledge, none of the previous research has examined interaction between Japanese male strangers or compared that interaction to strangers interacting in the U.S. Hopefully my research will begin to fill that gap, explain some cultural differences, and be beneficial to future research.

I compare how native English and Japanese male speakers interact in "small talk" that occurs during the initial phase of a relationship formation, when participants who 
have just met are waiting for a shared purpose. By analyzing pre-interview discourse data (male talk) I compare how native English speakers interact with each other in small talk with their Japanese counterparts. In addition, I examine perceptions of small talk by analyzing the responses to the interview questions about the social norms and values associated with small talk in each culture. My research questions are "Are there any differences in 'small talk' between English-speaking and Japanese men? If so, what are they?" 


\section{CHAPTER 2: RESEARCH METHODS}

In this chapter, I will present the research design for my study. Following the participants' information (Table B and C), I will also present data collection procedure and analytical procedure for the unmonitored pre-interview and interview data.

\subsection{Research Design}

The research questions in this study are: "Are there any differences in small talk between English-speaking and Japanese men? If so, what are they?" More specifically, I observe unmonitored small talk interaction between, on one hand, English-speaking male strangers and, on the other hand, Japanese male strangers in order to examine what types of topics they discuss and how conversations actually occur. Furthermore, I conduct interviews to analyze perceptions of small talk and how these perceptions reflect different social norms and values pertaining to real-life settings. My goal is to discover how small talk, a genre that commonly occurs in everyday interaction, differs in the two counties, what the keys to conducting successful small talk in public may be, how and when men talk to strangers, and how they feel about it. This study uses quantitative and qualitative methods to show how native English and Japanese male speakers interact during the initial phase of relationship formation, when participants who have just met are waiting for a shared purpose. The data on interaction during small talk come from the unmonitored pre-interview conversations between two participants, while the data on perceptions about small talk come from interviews. In the interviews, I explore perceptions of small talk in order to compare social norms and values between the U.S. and Japan. I ask the participants about their perceptions of small talk with strangers in the 
hope of identifying differences in social norms between the U.S. and Japan. Which group is more likely to engage in small talk with strangers? How does topic choice differ between the groups, and why? In what situations are U.S. and Japanese males likely to engage in small talk with strangers? These are the questions that I intend to answer through the interview.

In order to elicit conversation from both the English- and Japanese-speaking male pairs that is closely similar to candid small talk, I invited each pair to an interview session but left the pair alone in the interview room for about ten minutes before the actual interview began. When recruiting participants, I carefully arranged the interviews to guarantee the participants in each pair were strangers, and asked them to come to the group interview. I was not present at these interactions. The participants were aware that the recorder was on before I left the room. After 10 minutes of free (though recorded) small talk, I conducted a twenty-minute interview (in English for the U.S. participants and Japanese for the Japanese participants). I developed my own interview questions, which I revised after a pilot study. These questions asked how and when participants talk to strangers, and about the participants' ideas and attitudes about 'small talk' (see Appendix D). During the pilot study with Japanese students, it was very difficult for them to recall past experiences concerning small talk in an interview setting. Therefore, I asked questions about their past small talk experience again toward the end of each interview, in case the participants recalled something about their own experiences. After obtaining the interview data, I compared each group's perceptions of 'small talk,' and examined how these perceptions reflect different social norms and values. The interview was also 
recorded; the participants consented to the recording both verbally and in writing before the study began.

\subsection{Participants}

Participants for this study were recruited from Portland State University using posters and personal connections. I chose native Japanese-speaking participants who have been in the U.S. for less than two years, and U.S.-born participants whose native language is English. There were three English-speaking pairs and four Japanese pairs, labeled E-1, E-2, E-3, J-1, J-2, J-3, and J-4, with a total of fourteen participants. All participants were male and PSU undergraduates with the exception of one member of the E-2 pair, who had graduated about 6 months prior to this study.

\section{Table B: The U.S. Participants' Information}

\begin{tabular}{|c|c|c|c|c|c|c|c|}
\hline No. & Label & Name & Age & $\begin{array}{l}\text { Year } \\
\text { in } \\
\text { School }\end{array}$ & $\begin{array}{l}\text { Length of } \\
\text { Time Living } \\
\text { in the U.S. }\end{array}$ & Work experience & $\begin{array}{l}\text { Length of } \\
\text { Work } \\
\text { (months) }\end{array}$ \\
\hline$\# 1$ & & Alcibiades & 32 & senior & $29 \mathrm{yrs}$ & $\begin{array}{l}\text { 1. (part-time) Translator } \\
\text { 2. (part-time) } \\
\text { English Teacher }\end{array}$ & $\begin{array}{l}32 \\
18\end{array}$ \\
\hline$\# 2$ & E-1 & Kramer & 26 & junior & $26 \mathrm{yrs}$ & $\begin{array}{l}\text { 1. (part-time) } \\
\text { Video quality control } \\
\text { 2. (part-time) } \\
\text { Forklift driver }\end{array}$ & $\begin{array}{c}24 \\
2\end{array}$ \\
\hline$\# 3$ & & Sebastian & 26 & junior & $26 \mathrm{yrs}$ & $\begin{array}{l}\text { 1. (part-time) } \\
\text { Forklift driver } \\
\text { 2. Video Quality-control }\end{array}$ & $\begin{array}{c}2 \\
18\end{array}$ \\
\hline$\# 4$ & $\mathrm{E}-2$ & Wayne & 32 & alumni & 32 yrs & $\begin{array}{l}\text { 1. (full-time) } \\
\text { English teacher } \\
\text { 2. Event Coordinator }\end{array}$ & $\begin{array}{l}24 \\
36\end{array}$ \\
\hline$\# 5$ & E-3 & Frank & 23 & senior & $23 \mathrm{yrs}$ & $\begin{array}{l}\text { (part-time \& Intern) } \\
\text { Technical Writer/ } \\
\text { Copyeditor }\end{array}$ & 35 \\
\hline \#6 & & Marc & 24 & senior & $24 y r s$ & $\begin{array}{l}\text { 1. Reporter } \\
\text { 2. (part-time) Retail }\end{array}$ & $\begin{array}{l}1.5 \\
72\end{array}$ \\
\hline
\end{tabular}


Table C: The Japanese Participants' Information

\begin{tabular}{|c|c|c|c|c|c|c|c|}
\hline No. & Label & Name & Age & $\begin{array}{c}\text { Year } \\
\text { in School }\end{array}$ & $\begin{array}{l}\text { Length of } \\
\text { Stay } \\
\text { in the U.S. }\end{array}$ & Work Experience & $\begin{array}{l}\text { Length of } \\
\text { Work } \\
\text { (months) }\end{array}$ \\
\hline 1 & $\mathrm{~J}-1$ & Hiroshi & 25 & IELP & $\begin{array}{c}\text { a year and } \\
\text { half }\end{array}$ & $\begin{array}{l}\text { 1. (full-time) } \\
\text { Teaching Assistant } \\
\text { 2. (part-time) } \\
\text { Customer Service }\end{array}$ & $\begin{array}{l}18 \\
48\end{array}$ \\
\hline 2 & & Shin & 20 & junior & $\begin{array}{l}\text { less than a } \\
\text { month }\end{array}$ & (part-time) Web design & 24 \\
\hline 3 & 12 & Shinji & 25 & junior & $\begin{array}{l}\text { half an } \\
\text { year }\end{array}$ & $\begin{array}{l}\text { 1. (part-time) Cashier } \\
\text { 2. (part-time) Sales }\end{array}$ & $\begin{array}{l}12 \\
3\end{array}$ \\
\hline 4 & J- & Tadashi & 20 & sophomore & a year & $\begin{array}{l}\text { 1. (part-time) Waiter } \\
\text { 2. (part-time) Cook }\end{array}$ & $\begin{array}{l}28 \\
22\end{array}$ \\
\hline 5 & $\mathrm{~J}-3$ & Jiro & 21 & junior & $\begin{array}{l}\text { half an } \\
\text { year }\end{array}$ & $\begin{array}{l}\text { 1. (part-time) } \\
\text { Cram school teacher } \\
\text { 2. (part-time) Restaurant }\end{array}$ & $\begin{array}{l}6 \\
24\end{array}$ \\
\hline 6 & & Tomoki & 21 & junior & $\begin{array}{l}\text { half an } \\
\text { year }\end{array}$ & $\begin{array}{l}\text { 1. (part-time) Café Cook } \\
\text { 2. (part-time) Apparel }\end{array}$ & $\begin{array}{l}10 \\
6\end{array}$ \\
\hline 7 & & Kazu & 19 & sophomore & $\begin{array}{l}\text { less than a } \\
\text { month }\end{array}$ & (part-time)Restaurant & 9 \\
\hline 8 & $J-4$ & Kenji & 22 & IELP & a year & $\begin{array}{l}\text { (part-time)Hotel } \\
\text { /Customer Service }\end{array}$ & 24 \\
\hline
\end{tabular}

All of the participants were between the ages of 19 and 35.

\subsection{Data Collection Procedure}

I sought participants at the International Coffee Hours at Portland State University, through friends, via email requests for volunteers, or through active on-campus recruitment. When prospective participants responded to my request, I explained to them that my research topic is "U.S.-Japanese Communication," and promised my participants that their data would be confidential. I obtained their written permission before we began. An approval of the human subject research review is found in Appendix A. After consent was obtained from the participants, we set the date and time via email or in person for the interview. The participants consented to the recording both verbally and in writing before the study began. On the day of the interview, when the two participants arrived in the 
room, I asked them to wait for ten minutes while I went to buy some drinks. I began recording their conversation and stepped out of the room. After ten minutes, I returned to the room and conducted a twenty-minute interview (in English for the U.S. participants and in Japanese for the Japanese participants). The questions I asked during the interview were developed into an outline for my research questions. I asked the participants about how and when they talk with strangers, what topics they discuss, and what their ideas about and attitudes are toward small talk. Consent to record the interview sessions was obtained from the participants as well.

\subsection{Analytical Procedure for Small Talk Phase}

\subsubsection{Topics}

The recorded pre-interview conversations were transcribed and analyzed in order to identify and classify the topics participants discussed. The identified topics were sorted into five categories according to themes. Category one is 'research-related,' which included discussion related to this research study, such as how they became involved in the interview, how they know me, and thoughts about the interview room and the foods I served them. The second category is 'basic information about self,' which is a personal profile covering things such as what they study, what they like to do, who they know, and all kinds of information about what they have been doing. The third category is 'factual information,' which is somewhat related to the second category but more based on nonpersonal information, such as how to analyze Kanji, how French colonies got started, and so on. The fourth category covers 'living in the U.S.,' which included how the weather in Portland changes, U.S. laws, living with roommates, and all other ways in which the U.S. is different from Japan. Finally, category five covers 'personal concerns,' which includes 
problems, worries, gossip, and personal stories. 'Gossip' is talking about a third person's personal or private information. When they talked about mutual friends, such as by asking "Do you know Ms. Tanaka?," I classified it as category two ("basic information about self'). When they talked about a third person's skills or personal information, I classified it as 'gossip' and included it in category five.

After I classified all the topics into the five categories, I measured the time/length of each topic discussed by the U.S. and Japanese participants to find out any differences in the ways they talked about the topics.

\subsubsection{How Participants Use Pauses or Silence}

I focus on the pause because previous researchers have shown the use of silence and toleration of silences differs depending on culture (Yamada, 1997; Nakane, 2006; Roberts, 2011; Coupland, 2000; Roberts, Margutti, \& Takano, 2011). Moreover, Jaworski mentions that a pause in conversation with close friends or significant others is different from silence in conversation with a stranger. A pause or silence in conversation with friends can be just a restrained moment, with no awkwardness or hidden meaning. Jaworski (2000) argues that, "in certain types of interpersonal relations, most notably intimacy and detachment, silence is common and/or desirable and/or a possible vehicle of phaticity" (p.128). Not many researchers have studied what happens during silence in non-institutional small talk between strangers: therefore, I examine pauses that occur in the unmonitored pre-interview waiting room setting.

I focused on the pauses in the participants' conversations of three seconds or longer. Initially I included pauses of two seconds or longer in my analysis. However, I eventually decided to analyze pauses of three seconds or longer because those pauses 
frequently seemed awkward and unnatural, while pauses that were shorter than three seconds did not have the same feeling. More specifically, the shorter pauses did not interrupt an ongoing conversation. When a long pause occurred, the participants initiated a new topic, made unrelated or soliloquy-like remarks, or used backchannels. Thus, I focused on pauses of three seconds or longer and noted the frequency of such pauses for both the U.S. and Japanese pairs.

\subsubsection{Loop Sequence in Small Talk}

I examine whether loop sequences occur in the U.S. and Japanese small talk by scrutinizing the moment before a pause or silence, which often coincides with the ending of a topic. Sacks et al (1974) calls this moment the 'turn-relevance place (TRP)' or 'possible completion points (PCP),' which occurs when the interlocutors negotiate the floor structure with each other.

Iwasaki (1997:673) defines a loop sequence as “a turn-taking pattern consisting of a consecutive sequence of backchannel and back-backchannel expressions, produced by different speakers." He examined a narrative consisting of participants' experience during the Northridge earthquake and found that the loop sequence appeared more frequently in Japanese conversation than in conversations in English or Thai.

A basis for the loop sequence is the turn-taking mechanism, which is explained by Sacks et al. (1974):

(1) For any turn, at the initial transition-relevance place of an initial turn constructional unit:

(a) If the turn-so-far is so constructed as to involve the use of a 'current speaker selects next' technique, then the party so selected has the right and is obliged to take the next turn to speak; no others have such rights or 
obligations, and transfer occurs at that place.

(b) If the turn-so-far is so constructed as to involve the use of a 'current speaker selects next' technique, then self-selection for next speakership may, but need not, be instituted; first starter acquires rights to a turn, and transfer occurs at that place.

(c) If the turn-so-far is so constructed as not to involve the use of a 'current speaker selects next' technique, then current speaker may, but need not continue, unless another self-selects.

(2) If, at the initial transition-relevance place of an initial turn-constructional unit, neither $1 \mathrm{a}$ nor $1 \mathrm{~b}$ has operated, and following the provision of $1 \mathrm{c}$, current speaker has continued, then the rule-set a-c re-applies at the next transition-relevance place, and recursively at each next transitionrelevance place, until transfer is effected. (704)

These unwritten rules are followed through by interlocutors within conversation, and interlocutors quickly judge other interlocutors' reactions and continue creating the turn constructional unit. Sacks et al. (1974) show that during the turn-constructional unit (TCU) (which occurs when interlocutors are having a conversation), there is a certain point (transition relevance place, or TRP) where the speakers could change, or continue talking. Sacks et al. (1974) point out that when the current speaker does not select a next speaker, it is acceptable for another interlocutor to self-select and begin speaking, or for the current speaker to continue. Iwasaki (1997) states that loop sequences provide an opportunity for interlocutors to negotiate floor structure, the topic and the person who will develop the topic (p.670). He also introduces functions of the loop sequence such as 'prelude,' 'reconstruction,' and 'open floor.' 'Prelude' is an introduction to the floor transition which “... is not immediately followed by floor holder shift, but initiates an exchange of turns as if it is a prelude to such a shift" (p.678). 'Reconstruction' occurs when the current speaker is allowed to continue holding the floor after a loop sequence 
(p.680). 'Open floor' refers to the cooperative creation of a topic when no speaker has the floor and no new topic is introduced (p.683). I observe whether loop sequences occur in the small talk of the U.S. and Japanese participants.

Analyzing how interlocutors negotiate at the TRP and PCP, in other words, how the U.S. and Japanese participants operate turn-taking, enables us to discover how conversation actually occurs in real-life language use and compare both groups' small talk operations.

\subsection{Analytical Procedure for Interview}

The interview conversations were recorded, transcribed and analyzed in order to identify major differences and similarities between the U.S. and Japanese male participants. At first, I focused on outstanding responses, and then I categorized their responses by questions, such as locations and situations where they talk to strangers and questions about their reactions to and stance toward small talk situations based on their personal experiences. Then, I compared these responses by category between the U.S. and Japanese participants in order to answer my research questions. 


\section{CHAPTER 3:}

ANALYSIS

In the following three sections, I analyze what kinds of topics participants discussed, how the participants used the pause or silence, and how loop sequences occurred in small talk. I will also present one noteworthy difference between the two groups. Finally, I will show the findings from the interview about 'small talk.'

\subsection{The Unmonitored Pre-Interview Conversation}

\subsubsection{Topics Participants Discussed}

Since all the participants are students, both groups discussed topics related to school such as their major, specific classes, and school activities. As I wrote in the analytical procedure section in Chapter 3, I found five categories of topic in the small talk: 'research-related,' 'basic information about self,' 'factual information,' 'living in the U.S.,' and 'personal concerns.'

Table D shows the five categories along with specific topics that were brought up by each of the U.S. and Japanese groups. 


\section{Table D: Topics Participants Discussed}

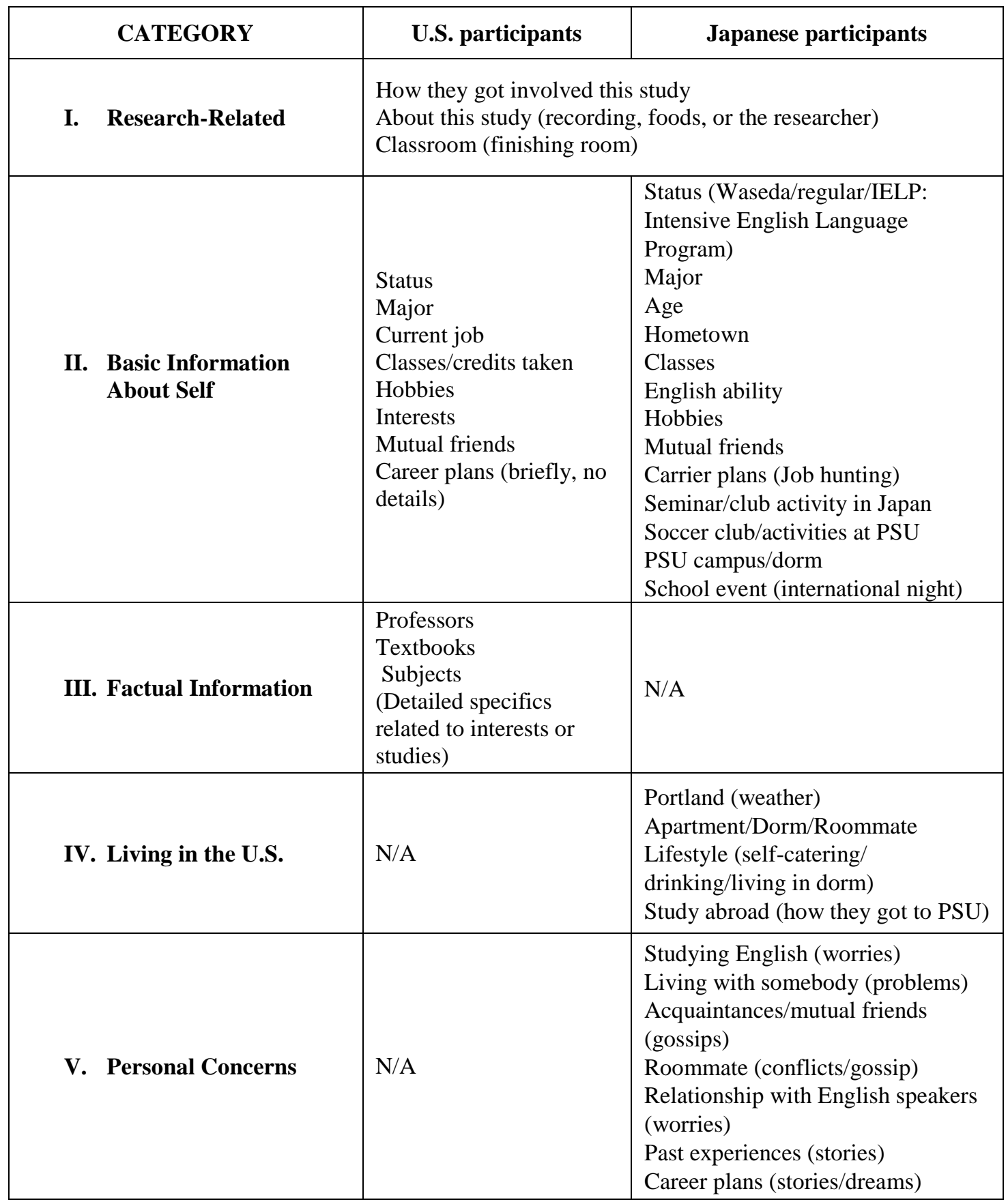

Both the U.S. and Japanese participants talked about Category One ('researchrelated'), and 'Category Two ('basic information about self'), but the U.S. participants often talked about Category Three ('factual information), while the Japanese did not talk 
about this at all. Similarly, although the Japanese participants discussed category five ('personal concerns') frequently, the U.S. participants did not mention it at all. As for Category Four ('living in the U.S.'), only the Japanese participants talked about this topic frequently because they are now in the U.S. and far away from their home. For the U.S. participants, of course, 'living in the U.S.' did not come up as a topic. Therefore, Category Four ('living in the U.S.') will not be included in my analysis because I cannot show that this difference in topic choice was due to cultural differences concerning topic rather than to their different living environment and circumstances.

Although both the U.S. and Japanese participants discussed Category Two ('basic information about self'), the Japanese participants discussed age (see table D), which was never brought up in the U.S. conversations. Some Japanese participants directly asked each others' age ("E-, ima oikutu desu ka" [so how old are you?]), and others implicitly asked questions about age and the year of graduation ("Ima sin-yonen desu ka" [are you a new senior now?]). 
Table E: Time/Length of Topics Discussed by the U.S. and Japanese Participants (in seconds)

\begin{tabular}{|c|c|c|c|c|c|c|c|c|}
\hline CATEGORY & Topic\# & E-1 & E-2 & E-3 & $\mathbf{J}-1$ & $\mathrm{~J}-2$ & $\mathbf{J}-3$ & $\mathrm{~J}-4$ \\
\hline \multirow{7}{*}{ I. Research-Related } & $\# 1$ & 13 & 58 & 28 & 0 & 53 & 6 & 0 \\
\hline & $\# 2$ & $(97 *)$ & 10 & 7 & & 16 & 16 & \\
\hline & $\# 3$ & 3 & & 10 & & 9 & 17 & \\
\hline & $\# 4$ & 45 & & 52 & & & & \\
\hline & $\# 5$ & 17 & & & & & & \\
\hline & $\# 6$ & 15 & & & & & & \\
\hline & $\# 7$ & 133 & & & & & & \\
\hline \multirow{14}{*}{ II. Basic Information About Self } & SUM & 226 & 68 & 97 & 0 & 78 & 39 & 0 \\
\hline & AVE & 38 & 34 & 24 & 0 & 26 & 13 & 0 \\
\hline & $\# 1$ & 88 & 110 & 143 & 55 & 114 & 20 & 30 \\
\hline & $\# 2$ & & 101 & 49 & 57 & 22 & 26 & 32 \\
\hline & $\# 3$ & & 34 & 170 & 32 & 41 & 30 & 44 \\
\hline & $\# 4$ & & & 12 & 24 & 74 & 88 & 22 \\
\hline & $\# 5$ & & & & 28 & 28 & 72 & 5 \\
\hline & $\# 6$ & & & & & 39 & 60 & 28 \\
\hline & $\# 7$ & & & & & 54 & 39 & 51 \\
\hline & $\# 8$ & & & & & 9 & 41 & 61 \\
\hline & $\# 9$ & & & & & & 13 & 43 \\
\hline & $\# 10$ & & & & & & & 20 \\
\hline & $\# 11$ & & & & & & & 7 \\
\hline & $\# 12$ & & & & & & & 36 \\
\hline & SUM & 88 & 245 & 374 & 196 & 381 & 389 & 379 \\
\hline & AVE & 88 & 82 & 94 & 39 & 48 & 43 & 32 \\
\hline \multirow{5}{*}{ III. Factual Information } & $\# 1$ & 155 & 269 & 45 & & & & \\
\hline & $\# 2$ & 78 & & 138 & & & & \\
\hline & $\# 3$ & 74 & & & & & & \\
\hline & SUM & 307 & 269 & 183 & $\mathbf{0}$ & $\mathbf{0}$ & $\mathbf{0}$ & $\mathbf{0}$ \\
\hline & AVE & 102 & 269 & 92 & & & & \\
\hline \multirow{7}{*}{ IV. Living in the U.S. } & $\# 1$ & & & & 55 & 9 & 36 & 4 \\
\hline & $\# 2$ & & & & 27 & 7 & 51 & 5 \\
\hline & $\# \mathbf{3}$ & & & & & & 4 & 10 \\
\hline & $\# 4$ & & & & & & & 12 \\
\hline & $\# 5$ & & & & & & & 49 \\
\hline & $\# 6$ & & & & & & & 3 \\
\hline & $\# 7$ & & & & & & & 29 \\
\hline & SUM & 0 & 0 & 0 & 82 & 15 & 91 & 112 \\
\hline & AVE & & & & 41 & 8 & 30 & 16 \\
\hline \multirow{7}{*}{ V. Personal Concerns } & $\# 1$ & & & & 4 & & 14 & 46 \\
\hline & $\# 2$ & & & & 64 & & 24 & 4 \\
\hline & $\# 3$ & & & & 130 & & 47 & 38 \\
\hline & $\# 4$ & & & & 38 & & 44 & \\
\hline & $\# 5$ & & & & & & 53 & \\
\hline & $\# 6$ & & & & & & 53 & \\
\hline & $\# 7$ & & & & & & 4 & \\
\hline
\end{tabular}




\begin{tabular}{|c|c|c|c|c|c|c|c|c|}
\hline & $\# \mathbf{8}$ & & & & & & 50 & \\
\hline & $\mathbf{\#}$ & & & & & & 14 & \\
\hline & SUM & 0 & 0 & 0 & 236 & 0 & 303 & 88 \\
\hline & AVE & & & & 59 & 0 & 34 & 29 \\
\hline
\end{tabular}

(*)E-1 pair spoke about topic \#1 in Japanese and English for 97 seconds. I will not count this in the calculation of the time/length.

Table E contains the time/length of discussion for each topic for both the U.S. and Japanese pairs, showing the most prominent differences between the U.S. and Japanese groups. Interestingly, the Japanese pairs discussed a single topic without pause for more than 100 seconds only twice; however, the U.S. participants did this eight times. For the three U.S. pairs, the length of time spent on the Category Two ("basic information about self") ranged from 82 to 94 seconds, while for the four Japanese pairs the length of time spent on the topic ranged from 32 to 48 seconds. The average time the U.S. pairs spent on topics in Category Two ("basic information about self") was 88 seconds; for the Japanese it was 40 seconds. Moreover, the number of topics within this category ranged from one to four for the U.S. pairs and five to twelve for three of the four Japanese pairs. This indicates that the Japanese participants discussed more topics within "basic information about self," but spent less time on each topic. The U.S. pairs discussed fewer topics in the same category but spent more time on each topic.

The U.S. participants tended to expand a topic by describing context in detail and continuing to contribute information. I labeled the U.S. participants' talk "informational talk" because they elaborated on class content and continued the information-sharing. The Japanese participants spent more time discussing personal matters such as worries about studying English, gossip about mutual friends, and stories of past experiences. The Japanese speakers were open and comprehensive in describing personal matters, so I have dubbed this "Personal Informational Talk." 
Excerpt 1 gives an example of U.S. participants' Informational Talk. In U.S. pair E-2, after Wayne learned that Sebastian and Wayne took the same class in the international department, Wayne continued to talk about the class, professor, materials, exam result and so on.

[Excerpt 1]

[English E-2]

W a y $\mathrm{n}$ e: And you have to have a lot of classes with Samantha Lester?

Sebastian: (laugh) huhuhuhuhu I don't have to but, yeah;;;

W a y $\mathrm{e}$ : no but she's like--not the head, but--.....

Sebastian: humhum

W a y n e: she's really high up the linguistics department, isn't she?

Sebastian: uhnnnnn yeah she's certainly been with the department for a long time I think since like 89 or something, yeah I mean a really long time and ;;; she was a he;;;;ad of ;;;;the IELP program for a number of years.???

W a y ne: Really?

Sebastian: I believe...

$\mathrm{W}$ a y $\mathrm{n}$ e: Most of the people at the coffee hours are IELP

Sebastian: yeah, so I think she was like a head of the department when she first came for a long time, and then unnn, I don't know if she has ever been to the head of applied linguistics program.

W a y $\mathrm{n}$ : uhm

Sebastian: But she is probably in the top tier group

W a y e: Yeah

Sebastian: How do you know Samantha Lester?

W a y n e: I ;; I had a required class called "Understanding the International Experience" Sebastian: hunhun

W a y n e: I had to take it when she was teaching.... I think she still teaches it now. She was teaching then...

$<$ Omitted 42 lines >

Sebastian: In which they didn't have 60 percentiles on that test, but let's just say you're there...

W a y n e: yeah

Sebastian: that some people move forward

W ay ne: yeah

Sebastian: and then some people actually go the other way like they'll;;;;

W a yn e: yeah

Sebastian: have more of a 
W a y ne: yeah depending on the?

Sebastian: stronger reactions;; like they'll take a step back before they take a step forward W ayn e: yeah well they have that

Sebastian: yeah that chart

$<$ Continued the conversation, omitted 22 lines $>$ (For details see Appendix E)

Wayne and Sebastian continued to talk about the classes--professor, materials, exam results and so on--for 269 seconds (4 minutes and 29 seconds). Wayne brought up the questions about classes to Sebastian, and Sebastian was willing to reply and expand the conversation. Such giving and taking (exchange of) information may be the key to continuing a conversation in English.

According to Tannen (1991), “...women and men are both interested in information--only different kinds" (p.303). Tannen argues that men often do report-talk while women often do rapport-talk. These two types of talk are different, because reporttalk is all about impersonal information while rapport-talk is about personal information. The analysis of the topics in the pre-interview phases shows that male English speakers, when they first meet strangers (with whom they have to spend time in the process of completing a goal), tended to end up conducting informational talk; that is, they were exchanging or sharing information, such as class details, textbooks (E-1), French Colonial history (E-3) and so on. The U.S. participants in this study tended to have specific information-oriented conversations, i.e. informational talk.

The Japanese participants tended to share personal information during small talk. Excerpt 2 gives an example of the Japanese participants' "Personal Informational Talk." After Shin and Hiroshi had talked for about five minutes, Shin introduced the topic of 
Hiroshi's relationship with English speakers by asking if Hiroshi already has a good friend in the U.S.

[Excerpt 2]

[Japanese J-1]

(1) S h i n : 結構もうこっちであの現地の人と仲良くなってます?

Kekko moo kotti de ano genti no hito to nakayoku natte masu

(2) Hiroshi: うーーん。それこそ親友みたいになるには。。。なかなか難しいね。 Uuun. sorekoso shinyuu mitaini naruniwa....... nakanaka muzukasii ne.

(3) Shin：ですよね desu yone

(4) Hiroshi: やっぱ言葉の壁もあるし、ただまあ、 yappa kotoba no kabe mo arushi, tadamaa,

いろいろそのアメリカ人のネットワークを広げれば、 iroiro sono amerika jin no nettowa-ku wo hirogereba

(5) Sh in: あー

A-

(6) Hiroshi: まあ、親友までにならなくても

Maa, shinyuu made ni naranakute mo

(7) Shin：あー

A-

[English]

(1) S h i n : Are you getting along with the local people [English speakers] yet ?

(2) Hiroshi: Well......becoming close friends...it's difficult [for me]...

(3) S h i n : Right?

(4) Hiroshi: There's the language barrier, though, but well...we could expand our American network....

(5) S h in: Yeah.

(6) Hiroshi: And, well, we don't have to be close friends [in order to become friends with English speakers]....

(7) S h in: Yeah.

Shin's questions “kekko moo kotti de ano genti no hito to nakayoku natte masu, [Are you getting along with the local people [English speakers] yet?]" (1) implies that he is curious 
about Hiroshi's lifestyle or relationships with English speakers. Hiroshi replied by expressing that these relationships are difficult for him as well: "Uuun. sorekoso shinyuu mitai ni naru ni wa....... nakanaka muzukasii ne [Well......becoming close friends...it's difficult [for me]...]" (2). This indicates that Shin was conducting the conversation by asking for Hiroshi's personal stories, which were often related to Shin's life or current worries. After Shin's questions, Hiroshi was willing to share his personal experiences and furthermore gave some advice to Shin, which is 'personal informational talk.'

Similarly, Excerpt 3 is another example of Japanese participants discussing personal problems or concerns. After they had talked about different topics, Kazu started talking about his soccer club.

[Excerpt 3]

[Japanese J-4]

(1) Kazu: 月水金プラス練習試合が土日のどっちか。結構きついっす。(笑い)

Getusuikin purasu rensyuujiai ga doniti no dotti ka. kekkoo kituissu. (laugh)

(2) Kenji: それ、部活やん。ふふふふ(笑い)

Sore, bukatu yan. huhuhu (laugh)

(3) Kazu: 本当に部活なんすよ。ふふ(笑い)；；。

Hontoo ni bukatu nan su yo. huhu (laugh).

だからちよっとどうしょうかなと思って

Dakara tyotto doo shiyoo ka na tto omotte.

(4) Kazu: そのだから入ろうか入らないかみたいの迷ってて

Sono dakara hairou ka hairanai ka mitai no mayote te...

[English]

(1) Kazu: Monday Wednesday and Friday, and the tournaments are on the weekends. It's quite tough [schedule]

(2) Kenji: This is [serious] club! haha (laugh)

(3) Kazu: Yes, this is [serious] club. haha (laugh) So... 
I was thinking what I am going to do.

(4) Kazu: So that means I am still of two minds about....[continuing with the soccer club] Kazu talked about his soccer club and resumed discussion of his concerns in (3). Kazu's additional comment, "Dakara tyotto doo siyoo ka na to omotte [So.... I was thinking what I am going to do]" (4) shows how Kazu raises his concerns. Kazu continues to mention his feelings: "sono dakara hairou ka hairanai ka mitai no mayote te... [So that means I am still of two minds about... [continuing with the soccer club]]" (4). He expressed his desire to be part of his soccer club (4), and mentioned that he is indecisive about whether or not to continue with it.

In addition to the personal concerns, the Japanese participants gossiped. Excerpt 4 demonstrates that as Tomoki questions Jiro about their mutual friends' relationship:

[Excerpt 4]

[Japanese J-3]

(1) Tomoki: 木村さんとしずかさんって付き合ってるんですか?

Kimura-san to Shizuka-san tte tukiatte ru n desu ka?

(2) J i r o: へえ! ?

Heee!?

(3) Tomoki: つきあってないっすか?いや一いつも一緒にいるんで、仲いいなーと Tukiatte nai ssu ka? Iyaaaa itu mo issyo ni iru n de, naka ii naa to

(4) J i r o: そんなことは全くない気がする。 Sonna koto wa mattaku nai ki ga suru.

(5) Tomoki: ふーん

Huuuun.

(6) J i r o：まっ木村は木村で彼女がいるんじゃないかな。

Ma-, Kimura wa Kimura de kanojo ga iru nj ya nai ka na.

(7) Tomoki: あっそうなんすか。

A-soo nan su ka.

[English]

(1) Tomoki: Are Kimura-san and Shizuka-san dating?

(2) J i r o: What!?

(3) Tomoki: Aren't they dating? Well, they're together all the time, so I thought that they seemed really close.... 
(4) J i r o: I feel like that can't be it at all.

(5) Tomoki: Hmmm.

(6) J i r o: Well, I guess it is Kimura, so he would have a girlfriend.

(7) Tomoki: Oh, is that so?

Tomoki’s question, “Kimura-san to Shizuka-san tte tukiatte ru n desu ka? [Are Kimurasan and Shizuka-san dating?]" (1), shows that Tomoki was prying into their mutual friends' Kimura and Shizuka's relationship. Tomoki further explained that they are: “tukiatte nai ssu ka? Iyaaaa itumo issyoni irunde, nakaii na- to [Aren't they dating? Well, they're together all the time, so I thought that they seemed really close....]" (3). Tomoki described that he often saw Kimura and Shizuka hang out together, and had assumed that they were in an intimate relationship and asked Jiro to confirm this suspicion. Jiro replied that "Ma-, Kimura wa Kimura de kanojyo ga irunjya nai kana- [It is Kimura, so he would have a girlfriend]" (6).

The Japanese participants tended to present personal stories or problems, and they were likely to express worries, share dilemmas, and gossip, which did not occur in the U.S. small talk. Three out of four Japanese pairs discussed their personal stories, worries or gossip after they talked about each other's background and school-related topics. The U.S. pairs, on the other hand, did not talk extensively about personal matters (especially their deeply concerning problems, feelings, or gossip) but instead gave factual information. This outcome stands in agreement with Tannen, who discovered different conversational styles: report-talk and rapport-talk. This is not to say that Japanese speakers are always perceived to be using women's rapport-talk and English-speakers using men's report-talk; however, as a matter of fact, this study's Japanese participants may send a message of rapport by discussing their personal stories, worries or gossip. In 
other words, the Japanese participants tended to express their inner feelings and conduct personal informational talk. Sharing personal experiences may be crucial to conducting small talk in Japanese.

\subsubsection{How Participants Use the Pause or Silence}

I identified all the pauses in my participants' conversations of three seconds or more, and have catalogued them in the following table:

Table F: Examination of Pauses Longer Than Three Seconds for the U.S. and the Japanese Pairs (seconds)

\begin{tabular}{|c|c|c|c|c|c|c|c|}
\hline & E-1 & E-2 & E-3 & $\mathrm{J}-1$ & $\mathrm{~J}-2$ & $\mathbf{J}-3$ & $\mathrm{~J}-4$ \\
\hline$\# 1$ & $\underline{6}$ & $\underline{4}$ & 3 & 3 & 4 & 8 & 3 \\
\hline$\# 2$ & 4 & 4 & 3 & 6 & 6 & 5 & 3 \\
\hline$\# 3$ & 5 & & 3 & 7 & 4 & 4 & 3 \\
\hline$\# 4$ & 5 & & 3 & 3 & 10 & 7 & 6 \\
\hline$\# 5$ & 5 & & $\underline{8}$ & 3 & 4 & 3 & 5 \\
\hline$\# 6$ & 3 & & 3 & 3 & 4 & 4 & 3 \\
\hline$\# 7$ & 3 & & 3 & 3 & 8 & 7 & 4 \\
\hline$\# 8$ & 3 & & 3 & 4 & 8 & 5 & 3 \\
\hline$\# 9$ & & & & 4 & 19 & $\underline{16}$ & 5 \\
\hline$\# 10$ & & & & 5 & 9 & 3 & 7 \\
\hline$\# 11$ & & & & 4 & $\underline{34}$ & 4 & 3 \\
\hline$\# 12$ & & & & 5 & 17 & 7 & 4 \\
\hline$\# 13$ & & & & $\underline{17}$ & 12 & 3 & 4 \\
\hline$\# 14$ & & & & & & 3 & 5 \\
\hline$\# 15$ & & & & & & 6 & 3 \\
\hline$\# 16$ & & & & & & 6 & 6 \\
\hline$\# 17$ & & & & & & 4 & $\underline{10}$ \\
\hline$\# 18$ & & & & & & 4 & 5 \\
\hline$\# 19$ & & & & & & 3 & 4 \\
\hline$\# 20$ & & & & & & 3 & 3 \\
\hline SUM(sec) & 34 & 8 & 29 & 67 & 139 & 98 & 89 \\
\hline Ave(sec) & 4.3 & 4.0 & 3.6 & 5.2 & 10.7 & 4.9 & 4.5 \\
\hline $\operatorname{Max}(\sec )$ & 6 & 4 & 8 & 17 & 34 & 16 & 10 \\
\hline Frequency(times) & 8 & 2 & 8 & 13 & 13 & 20 & 20 \\
\hline $\begin{array}{c}\text { Frequency } \\
\text { AVE(times) } \\
\end{array}$ & \multicolumn{3}{|c|}{6 times } & \multicolumn{4}{|c|}{16 times } \\
\hline
\end{tabular}

* Underlined times are the longest pause for each pair. 
As Table F shows, pauses of more than three seconds appeared more frequently in the Japanese conversations than in the U.S. ones, and the longest pause or silence was 34 seconds in Japanese compared to 8 seconds in English conversation. The average length of a pause/silence in the Japanese small talk was 6.3 seconds and in the U.S. small talk was 4.0, giving a difference of 2.3 seconds. The average number of pauses/silence in the U.S. conversations was 6 , and the average for the Japanese small talk was 16 . This means that the Japanese participants tended to have many pauses/silences compared to their U.S. counterparts.

The high frequency of pauses in the Japanese small talk does not necessarily mean they are tolerant of silence. The Japanese participants indicated discomfort with silences during small talk with their interlocutor. The following segment in Excerpt 5 is an example of a series of four substantial pauses that occurred in a Japanese pair. It indicates awkwardness as the participants fill the silence with backchannels, soliloquylike remarks, and a sigh. Prior to the segment in the excerpt, Shinji and Tadashi had been talking for about eight minutes and thirty seconds. Shinji and Tadashi found out that they both knew the same person, but Tadashi mentioned that this person was not his friend; he just knew the person. After an eight-second pause, during which initiated conversation on a new theme, Shinji made a soliloquy-like remark and Tadashi sighed loudly.

\section{[Excerpt 5]}

[Japanese J-2]

(1) Shinji laughed at Tadashi's comment: "No I just know him, [but he does not know me]." Shinji：あははは(笑)

(4 seconds) Ahahaha (laugh)

(2) Shinji: そっかそっか。 Sokka sokka I see I see

\section{(8 seconds)}


(3) Shinji: うまいな。(独り言のような発言)

Umai na...

(8 seconds)

It's tasty [food].... (soliloquy-like remarks)

(4) Tadashi: はあーー (ため息)

(19 seconds)

Haaaaa (sigh)

(5) Tadashi: えレギュラーのクラスってやっぱムズいっすか?

E-, reguraa no kurasu tte yappa muzui ssuka

So I thought that the regular class is difficult, right?

Shinji laughed at Tadashi's statement, and after four seconds, Shinji reconfirmed what

Tadashi said "Sokka sokka [I see I see]" (2), and after an eight-second silence, Shinji

spoke again, with a soliloquy-like remark about the taste of the food: "Umai na...[It's

tasty ....]" (3). Tadashi did not react to Shinji’s comment. Furthermore, after eight

seconds of silence, Tadashi sighed loudly (line 4). Finally, after 19 seconds of silence,

Tadashi asked a question about regular class to Shinji "E-, reguraa no kurasu tte yappa

muzui ssu ka [so I thought that the regular class is difficult, right?]” (5).

Hasegawa and Gudykunst (1998) examined the attitude towards silence in Japan

and the U.S. and found that Japanese have a more negative view of silence than do

Americans when communicating with strangers. Their research used a questionnaire that

asked about the use of silence in several different relationships, so it is not clear how

people react to silence in reality. My study suggests that the Japanese participants may

have a negative view of silence during conversation with strangers because the Japanese

participants made an effort to fill in silence, or made noise during silences. I wondered

how they felt about the 19-second silence, so after the interview, I asked for their feelings

via email. Tadashi never responded to my inquiry, so I do not know how he felt about the

silence. Shinji responded that "It was the first time [I met] him, so I felt pressured to talk;

I felt that I was looking for the theme of our conversation. But when I was eating, I didn't 
care about the silence much." This statement may show that Shinji felt uncomfortable or awkward; he was looking for a new theme for their conversation. However, he did not have one, so Shinji made a comment about the food instead. This indicates that Shinji may have been uncomfortable during silence while engaging in small talk with a stranger; therefore, he filled in the silence with the soliloquy-like remark. He did not care about the 19-second silence though, as long as he was doing something else (i.e., eating) other than talking.

One similarity between the two groups was that when a relatively long pause occurred both the U.S. and Japanese participants attempted to fill the pause by repeating topics. Or they filled in the silence with discussion of topics on which they shared knowledge, or about the research study in which they were participating.

Table G: Initial Remarks Following Silence

\begin{tabular}{|c|c|c|}
\hline $\begin{array}{l}\text { U.S. } \\
\text { pair }\end{array}$ & $\begin{array}{l}\text { Length of } \\
\text { Silence (sec) }\end{array}$ & Remarks \\
\hline E-1 & 7 & "Right at lunch time too. We are lucky." \\
\hline E-2 & 4 & "yeah... I know it, it was [recording our conversation]." \\
\hline E-3 & 10 & "so [the researcher] just ran in to you totally randomly, huh?" \\
\hline \multicolumn{3}{|c|}{$\begin{array}{c}\text { Japanese } \\
\text { pair }\end{array}$} \\
\hline $\mathrm{J}-1$ & 6 & "yappa apaato kiree desu ka? [Is your apartment clean?]" \\
\hline \multirow[t]{3}{*}{$\mathrm{J}-2$} & 9 & $\begin{array}{l}\text { "kyoo dono kurai kono intabyuu toka kakaru n desu ka ne? } \\
\text { [Do you know how long this interview will take?]" }\end{array}$ \\
\hline & 9 & "Chie-san osoi ssu ne? [Chie is late, isn't she?]" \\
\hline & 34 & $\begin{array}{l}\text { "jizen ni shitumon kiit okeba yokatta to omotte } \\
\text { [I thought that I should have asked the questions [ which the } \\
\text { interviewer will ask us in this interview] beforehand." }\end{array}$ \\
\hline $\mathrm{J}-3$ & 16 & "ondiin desu ka ? [Do you live in Ondine?]" \\
\hline $\mathrm{J}-4$ & 8 & $\begin{array}{l}\text { "koko tte nan yatta kke apaato no namae } \\
\text { [What was the name of your apartment?]" }\end{array}$ \\
\hline
\end{tabular}

Pauses mean that the participants had exhausted the topic of conversation, and these silences sometimes appeared awkward; in such cases, the participants discussed this 
study or shared topics of interest to fill the silence. The participants returned frequently to the same topics, and repeated topics within the same conversation. This shows that they are similar in the ways they filled silence during small talk with strangers in that they rely on shared knowledge and things available in the immediate situation.

\subsubsection{Loop Sequence in Small Talk}

Table H shows the frequency of loop sequences for the U.S. and Japanese pairs in small talk.

Table H: Frequency of Loop-Sequence for the U.S. and Japanese Pairs

\begin{tabular}{cccccccc}
\hline \hline & \multicolumn{3}{c}{ U.S. participant } & \multicolumn{5}{c}{ Japanese participants } \\
\hline \hline Loop sequence[ SUM] & \multicolumn{1}{c}{$\mathbf{1}$} & $\mathbf{5}$ & & $\mathbf{8}$ & \\
\hline \hline E-1 & E-2 & E-3 & J-1 & J-2 & J-3 & J-4 \\
\hline \hline Floor reconstruction & 0 & 0 & 0 & 2 & 0 & 0 & 3 \\
Floor transition & 1 & 0 & 0 & 0 & 0 & 0 & 2 \\
\hline \hline SUM & 1 & 0 & 0 & 3 & 0 & 0 & 5
\end{tabular}

Even though the small talk in this study did not occur in a storytelling setting as it did in Iwasaki's research, the loop sequence still appeared in participants' conversations. As Table H shows, the frequency of loop sequences differs between the U.S. and Japanese participants. While only one loop sequence occurred in the U.S. small talk, the Japanese small talk data contained loop sequences eight times.

Excerpt 6 shows the first loop sequence, which is followed by Hiroshi, the previous speaker, retaining the floor.

[Excerpt 6]

[Japanese J-1]

(Floor reconstruction)

Shin introduced the topic of Hiroshi's relationship with English speakers in the U.S.

\begin{tabular}{|c|c|c|}
\hline & Hiroshi & Shin \\
\hline
\end{tabular}




\begin{tabular}{|c|l|l|}
\hline 1 & $\begin{array}{l}\text { yappa gengo no kabe mo arusi, tadama-, } \\
\text { iroiro sono amerika jin no nettowa-ku o } \\
\text { hiroge reba }\end{array}$ & \\
\hline 2 & & A- \\
\hline 3 & ma-, sinyuu made ni naranaku temo & A- \\
\hline 4 & & \\
\hline 5 & $\boldsymbol{u}-\boldsymbol{n}$ & \\
\hline 6 & Syottyuu ironna syurui no hito to asobeba & \\
\hline
\end{tabular}

[English]

\begin{tabular}{|c|l|l|}
\hline & \multicolumn{1}{|c|}{ Hiroshi } & \\
\hline 1 & $\begin{array}{l}\text { there is a language barrier, though, but } \\
\text { well..we could expand our American } \\
\text { network.... }\end{array}$ & \\
\hline 2 & & yeah \\
\hline 3 & $\begin{array}{l}\text { so we don't have to be a best friend [in order } \\
\text { to become a friend with English speakers]... }\end{array}$ & \\
\hline 4 & & yeah \\
\hline 5 & u-n & \\
\hline 6 & $\begin{array}{l}\text { we can hang out with many different kinds of } \\
\text { people... }\end{array}$ & \\
\hline
\end{tabular}

Shin was concerned about relationships with Americans, so he asked Hiroshi how he is

doing with that. Hiroshi states that "Ma-, sinyuu made ni naranaku temo [we don't have

to be a best friend [in order to become a friend with an English speaker]]" (3). To this

statement, Shin gives the non-lexical backchannel expression " $A h-$," (the 'loop-head') (4), and Hiroshi offers back-backchannel behavior " $U-n$ " (5). After the loop sequence here, Hiroshi continued to develop the floor.

While the Japanese pairs demonstrated both floor reconstruction and floor transition, the U.S. pairs exhibited floor transition as shown in Excerpt 7 below.

[Excerpt 7]

[English E-1]

(Floor transition)

Kramer and Alcibiades are talking about the study and what the participants were supposed to act. 


\begin{tabular}{|c|c|c|}
\hline & Alcibiades & Kramer \\
\hline \multicolumn{3}{|c|}{ Floor 1} \\
\hline 1 & $\begin{array}{l}\text { not supposed to let participants know too } \\
\text { much about what you are doing }\end{array}$ & \\
\hline 2 & & oh wow, \\
\hline 3 & $\begin{array}{l}\text { go home and read up and give answer they } \\
\text { would have if they hadn't educated } \\
\text { themselves, or try to be something that it's not }\end{array}$ & \\
\hline 4 & & ok...ok I understand that. \\
\hline 5 & humhum & \\
\hline \multicolumn{3}{|c|}{ (two seconds) } \\
\hline \multicolumn{3}{|c|}{ Floor 2} \\
\hline 6 & & $\begin{array}{l}\text { this--these are so good; I love matcha. Like } \\
\text { this is so good. }\end{array}$ \\
\hline
\end{tabular}

Alcibiades was talking about what the research participants should and should not do, which is "go home and read up and give answer they would have if they hadn't educated themselves, or try to be something that it's not" (3). To this response, Kramer indicates understanding by saying "Ok...ok I understand that" (4). Alcibiades responds to Kramer's phrasal backchannel with a non-lexical backchannel "humhum," which is the loop-tail (5). After the loop-sequence here, Kramer hold the floor, talked about the food they were eating, and expressed his appreciation: "This--these are so good, I love matcha. Like this is so good" (6). This loop-sequence indicates mutual floor negotiation by the two participants.

I also found one noteworthy difference between the two groups in the unmonitored pre-interview small talk; that is, frequent occurrences of soliloquy-like remarks in the Japanese small talk.

Within the 10 minutes of small talk, Japanese participants used soliloquy-like remarks to fill in the silence, such as "Umai na...[It's tasty [food]....]," "Waseda ka--[you go to Waseda University]," and "Nisyuukan ka--[ it has been two weeks]." These soliloquy-like remarks were found only once in the English conversations, while the Japanese pairs used them more than 10 times in total. I call soliloquy-like remarks 
"noncommittal remarks," because they are neither backchannel, nor back-backchannel, and in terms of linguistics form they can be sentences or sentence fragments with or without sentence-ending particles. Furthermore, the function of "noncommittal remarks" is very flexible. When an interlocutor voices "noncommittal remarks," the other interlocutor can choose to disregard or reply to what the first interlocutor said.

In the Japanese language, there are indirect expressions and expression that might be either statements or questions. It can sometimes be hard to tell which, and whether the person is talking to him/herself or asking the interlocutor a question. For instance, Ohama (2006) introduced 真偽疑問文 'Shingi gimon bun,' interrogative sentences in which question markers ' $k a$ ' are often absent. Ohama, referring to the National Institute for Japanese Language (1960: Cited in Ohama, 2006, p.155), mentions that these utterances indicate 判断への疑念の表現 ‘handan he no ginen no hyoogen' (an expression of skepticism about one's judgement), 確認要求の表現 ‘kakunin yookyuu no hyoogen' (an expression of request for acknowledgement), and 判定要求の表現 ‘hantee yookyuu no hyoogen' (an expression of request for judgment). The last two sentences assume that the speaker is requesting a judgment or decision about the contents; it is usually clear to the interlocutor that s/he is expected to respond somehow. However, according to Ohama (2006), the utterance 判断への疑念の表現 'handan he no ginen no hyoogen' (an expression of skepticism about one's judgment) may include the features of "noncommittal remarks" because the choice to reply to or disregard the remark lies with the receiver. 
When one interlocutor makes "noncommittal remarks," the other interlocutor may disregard or reply to him/her. In other words, in terms of holding the floor, the speaker of "noncommittal remarks" is not committed to holding the floor or giving it away to the other conversant. In this case, the original speaker accepts whatever happens next. If the other interlocutor asks questions about what the first interlocutor has just said, they continue with that topic, and if the other interlocutor dismisses what the first interlocutor said, this is also fine, and the floor remains as open. The flow of the conversation depends on what the receiver of the noncommittal remark feels to be appropriate.

\section{Table I: Varieties of Noncommittal Remarks}

\begin{tabular}{|c|c|c|c|}
\hline No & Label & Noncommittal Remarks & The Other Interlocutor's Reply \\
\hline$\# 1$ & $\mathrm{~J}-1$ & $\begin{array}{c}\text { "Nisyuukan } k a- \\
\text { [It has been two weeks]." }\end{array}$ & $\begin{array}{l}\text { Replied: "demo iruno jyuunigatu } \\
\text { madeshika inain desu yo [but I will be here } \\
\text { just until December.]" }\end{array}$ \\
\hline$\# 2$ & $\mathrm{~J}-1$ & $\begin{array}{c}\text { "Soodesuyonee....(quiet voice) } \\
\text { [it is...]." }\end{array}$ & Disregarded \\
\hline \#3 & $\mathrm{J}-1$ & $\begin{array}{c}\text { "Itinen } k a- \\
\text { [[you will be here for] a year]" }\end{array}$ & Disregarded \\
\hline \#4 & $\mathrm{J}-2$ & $\begin{array}{l}\text { "A-simatta kotti taberebayokatta } \\
\text { [Oh, I should have eaten this one]." }\end{array}$ & Disregarded \\
\hline$\# 5$ & $\mathrm{~J}-2$ & $\begin{array}{c}\text { "Yaruna aitu } \\
\text { [Good job [Satomi]]." }\end{array}$ & Disregarded \\
\hline \#6 & $\mathrm{J}-2$ & $\begin{array}{c}\text { "A-nodokawaitekita } \\
\text { [Ah-I am becoming thirsty]." }\end{array}$ & Disregarded \\
\hline$\# 7$ & $\mathrm{~J}-3$ & $\begin{array}{c}\text { "Kibowamata dekkakunattana- } \\
\text { [the scale [of my club] getting } \\
\text { bigger]." }\end{array}$ & Disregarded \\
\hline \#8 & $\mathrm{J}-3$ & $\begin{array}{l}\text { "Waritootonasiikee nanda- } \\
\text { [Sounds like [he is] the quiet } \\
\text { type...]]." }\end{array}$ & Replied: "Otonashii desune [he is quiet]" \\
\hline$\# 9$ & $\mathrm{~J}-4$ & $\begin{array}{l}\text { "tikoku sityatta } \\
\text { [I was late]." }\end{array}$ & Disregarded \\
\hline$\# 10$ & $\mathrm{~J}-4$ & $\begin{array}{l}\text { "Yabai ore gatturi kutteru } \\
\text { [Oh I am smashing [out]]." }\end{array}$ & Replied: haha (laughter token) \\
\hline
\end{tabular}

Table I shows the varieties of noncommittal remarks used by my participants, with examples of 10 noncommittal remarks and the responses provided by the 
corresponding interlocutor. The receivers of the noncommittal remarks replied or reacted (with a laugh) three times, while they disregarded the remarks seven times.

\subsection{The Interview}

I now turn to the findings from the interview data. After leaving each pair for 10 minutes, I returned to the interview room and conducted a twenty minute interview, during which I asked the following questions:

(1) In what kinds of situations do you talk to complete strangers? (どんな状況で 見知らぬ人と話します？)

Follow- up question: Have you ever enjoyed or had a good time talking with a stranger? If you have, please describe the circumstances and situation. (今まで見知らぬ人と話して、楽しかった、いい会話をしたという 経験はありますか。もしあれば、どういう状況だったのか教えていただき たいんですけど。)

(2) Usually we have everyday conversations with people we know, but there are occasions when we have conversations with strangers. I mean actual conversation, more than simple communication with a specific purpose, like asking for information or the set exchanges that come with service encounters. What are typical situations in which casual conversation can occur with strangers? (普段い ろんな場面で人と話すことがあると思うんですけど、例えば、道をきいたりとか 決まったあいさつを交わすとかではなく、特別な理由ではなく、見知らぬ人と話 す時はどんな時、どんな場面だと思いますか。）

(3) Please think for a moment about the conversation topics you discuss with friends, but which you probably would not discuss with strangers. What are some examples of each? What topics are easiest to talk about with strangers, and what topics are off-limits for discussion with strangers? (友達と話す内容を思い浮べ てもらってもいいですか。その中で、たぶんそれは見知らぬ人とは話さないなと 思う内容はどんなトピックだと思いますか。また、どんなトピックが見知らぬ人と 話しやすいですか。見知らぬ人と話さないと思うトッピックはどんなトピックです か。)

Follow-up question: Do you ever talk about private issues with strangers? (プライベートのことや自分のことについて話すことはあります？)

(4) Do you find it easy to discuss intimate things because you are talking with a stranger, someone you know you will never see again? (見知らぬ人、もう二度と 
会わないという人だからこそ、プライベートのことが話しやすいと思ったことはあ りますか。)

(5) What if you are in a doctor's waiting room or waiting for a bus? If a stranger suddenly starts talking to you, what goes through your mind? (病院で自分が呼ば れるのを待ってる時やバス停でバスを待っている自分を想像してみてもらっても いいですか。そのとき突然見知らぬ人が会話を始めてきたらどう思いますか。 OOさんのリアクションを教えてください。)

Follow-up question: What do you think when a stranger talks to you without specific purpose (like asking for information or directions? (特別 な目的がなく話しかけられたら、どう思いますか。OOさんのリアクション を教えてもらいたいんですけど。)

(6) How are your attitude and stance different when talking to friends and when talking to strangers? (友達と会話をするときと見知らぬ人と会話をするときと OO さんの接し方の何が違うと思いますか。)

(7) Do you think that conversations between strangers happen often in American/Japanese society? Please describe the most common circumstances and situation. (見知らぬ人と話すことは日本社会でよくあることだと思います？もし そうだとしたら、それはどういう状況だと思いますか。）

\subsubsection{Setting for Small Talk}

The first two questions deal with the situations in which the participants are willing to talk to strangers. Interestingly, the U.S. participants immediately replied to these questions, but the Japanese participants reacted with some difficulty by saying, " $E$-!?," "U------n," or "E--naidesu [well....there are no [such situations]]." They were surprised or puzzled by my questions and had to spend long time thinking about experience of talking to strangers. Table $\mathbf{J}$ shows a summary of the responses to the interview question regarding the location of small talk.

Table J: Place of Small Talk in the U.S. and Japanese Participants

\begin{tabular}{|l|l|l|l|}
\hline & & U.S. participants & Japanese participants \\
\hline \hline
\end{tabular}




\begin{tabular}{|c|c|c|c|}
\hline \multirow{3}{*}{$\begin{array}{c}\text { Off- } \\
\text { Campus }\end{array}$} & $\begin{array}{c}\text { Public } \\
\text { Transportation }\end{array}$ & $\begin{array}{l}\text { at the bus stop (6) } \\
\text { on the street (6) } \\
\text { on the Max (public } \\
\text { transportation) (6) } \\
\text { on the greyhound bus ( } 2 \text { ) } \\
\text { (long bus ride) }\end{array}$ & on the train (1) \\
\hline & Shops & $\begin{array}{l}\text { at the supermarket (2) } \\
\text { at Starbucks (1) } \\
\text { waiting room (1) }\end{array}$ & $\begin{array}{l}\text { at the bar (4) } \\
\text { at the supermarket (1) }\end{array}$ \\
\hline & Special Event & sports tournament (1) & $\begin{array}{l}\text { music concert (1) } \\
\text { sport tournament (1) } \\
\text { drinking party (4) }\end{array}$ \\
\hline On-Campus & & $\begin{array}{l}\text { in class } \\
\text { (the first day of class) (2) } \\
\text { international coffee hours } \\
\text { (school event) (2) } \\
\text { recreation center (1) }\end{array}$ & $\begin{array}{l}\text { in class } \\
\text { (the first day of class) (1) } \\
\text { in class (trying to catch up on } \\
\text { the material) (2) } \\
\text { cafeteria (1) }\end{array}$ \\
\hline
\end{tabular}

*Numbers in the parentheses indicate number of responses.

Since the participants were students, I categorized the location where they talk with strangers into on-campus and off-campus. The U.S. participants stated that they often talked to complete strangers in public, such as on public transit or at bus stops. On the other hand, only one of the eight Japanese participants (Shin) reported engaging in small talk in a public place. He emphasized that such situations were relatively rare; he said "[It's happened only on the] Sunday train and when there are few people." The other seven participants did not mention engaging in any small talk while using public transit. Shin also explained that when he was in the line at a supermarket, an old woman talked to him. Shinji was at a bar with his friends, and they started a conversation with the other group in the pub. But both of them stated that these experiences were fairly rare, while the English speakers gave many examples of such conversations with strangers. Kazu, a Japanese participant, said that, "If you are a normal Japanese person, and there is no specific purpose, you don’t talk to strangers, do you?" Jiro said, “There is no reason to 
talk to complete strangers.” The U.S. participants Sebastian and Wayne said that talking to strangers happens all the time, several times a day, but the Japanese participants had different experiences.

\subsubsection{The Types of Topics Participants Discussed (Off-Campus)}

I was curious as to what participants talk or talked about with strangers, and how they initiate conversations in public without a specific reason such as asking for directions. I asked the following questions:

(3) Please think for a moment about the conversation topics you discuss with friends, but which you probably would not discuss with strangers. What are some examples of each? What topics are easiest to talk about with strangers, and what topics are off-limits for discussion with strangers? (友達と話す内容を思い浮べ てもらってもいいですか。その中で、たぶんそれは見知らぬ人とは話さないなと 思う内容はどんなトピックだと思いますか。また、どんなトピックが見知らぬ人と 話しやすいですか。見知らぬ人と話さないと思うトッピックはどんなトピックです か。)

Follow-up question: Do you ever talk about private issues with strangers? (プライベートのことや自分のことについて話すことはあります？)

(4) Do you find it easy to discuss intimate things because you are talking with a stranger, someone you know you will never see again? (見知らぬ人、もう二度と 会わないという人だからこそ、プライベートのことが話しやすいと思ったことはあ りますか。)

Willingness to talk about personal issues varies individually according to individuals for both English speakers and Japanese people; however, one prominent difference is that the U.S. participants tend to talk with strangers by pointing out some object with which he can identify or relate. For example, a sports team affiliation or hometown T-shirt logo, or a book he has already read. Wayne mentions that, "If somebody talked to me about the book I am reading, I would get into the conversation, but I won't start the conversation." After giving this response, Wayne realized that he once initiated a conversation because 
he saw a guy wearing a cap with his hometown's name (Minneapolis) on it. Kramer told me a story about a time he overheard strangers' conversation on the bus, and jumped in. They were talking about music theory, and music composition, which was Kramer's major; he said that, "If people start talking about music, music theory, or composition, I can't hold back, I have to talk to them. If I know they are working on the music, I will want to help them; 'please let me do it!" Most of the U.S. participants had had a few good experiences talking to strangers. Alcibiades told me a story about a time he was on a long Greyhound bus ride, and had a good conversation with a stranger about evolution. He started the conversation "Because he said something patently false, scientifically wrong, so I had to call on it." However, at the end of the bus ride they exchanged numbers, and Alcibiades has stayed in touch with him to some extent. All six U.S. participants mentioned similar interactions, and said that while most of these conversations are relatively short, they are also common. Frank said that even when he was waiting for a bus, wearing headphones and reading a book, people still tried to talk to him.

\subsubsection{Why Do Participants Talk to Strangers? How Do They Feel About It?}

In order to find out the participants' reactions when they are talked to by a stranger and their surmisation as to why strangers have small talk, I asked my participants the following questions:

(5) What if you are in a doctor's waiting room or waiting for a bus? If a stranger suddenly starts talking to you, what goes through your mind? (病院で自分が呼ば れるのを待ってる時やバス停でバスを待っている自分を想像してみてもらっても いいですか。そのとき突然見知らぬ人が会話を始めてきたらどう思いますか。 OOさんのリアクションを教えてください。)

Follow-up question: What do you think when a stranger talks to you without specific purpose (like asking for information or directions?) (特別 


\section{な目的がなく話しかけられたら、どう思いますか。OOさんのリアクション を教えてもらいたいんですけど。)}

Frank said he would engage in small talk because "There is nothing to do when you are waiting for the Max." When he was waiting at the bus stop, reading a book and wearing headphones, sometimes people approached him and asked where he got his headphones, and why he picked that brand. Frank stated that, "Whether or not I would initiate a conversation with a stranger depends on my mood, but if or when somebody talks to me, it's not a big deal to close the book, just do that instead." He also mentions that some people have genuinely innocent questions. Frank asked a stranger for his feedback about a certain book, because Frank had already read it. He asked the stranger for his or her impressions simply out of curiosity. Like Frank, Sebastian also sometimes initiates conversation based on familiar affiliation on the outfit—he once said, "Hey man! Cool shorts!" to a guy wearing shorts with the "Kansas State University" logo. Sebastian says that he did this, perhaps, out of a desire for connection, and he does the same thing to all people he sees from Kansas: "I don't know why we have the tendency to point it out!" Similarly, Wayne mentioned that he often points out Minneapolis hats, and said that he does not think much about it: "It just happens. But I was comfortable enough to do that."

The Japanese participants were more likely to feel uncomfortable or confused when talked to by a stranger. Shinji said that, "At the beginning, there is a negative impression." Jiro said, "I feel that it is annoying, maybe [when that happens]," and Tadashi added that, "I've never had that kind of experience, so I would be surprised and suspicious of what they want." Tadashi told me a story of a time when he was at a baseball tournament in Tokyo. A man sitting next to Tadashi was talking to him, 
seemingly endlessly, until the game was over. Tadashi described this moment: "I found it annoying, but on the surface, I just said, like, "A soodesuka [Oh... is that so?]" to the man, but in my mind, I thought "Konoyarooo! [You bastard!].” Having these ambivalent feelings, Tadashi endured listening to the man for the entire game. Like Tadashi, Shinji

mentioned a story of a time when he was waiting for his friends at the station in Tokyo. A homeless man was talking to him about his life story continuously. Shinji also described his honest reaction; he felt like telling the man "Hayaku oware-Tumanne-! [finish up soon! [your story] is boring!].” However, Shinji also did not say anything, and waited until his friends had arrived. These examples show that talking with strangers was deeply memorable for the Japanese participants, because such situations are not common and are often uncomfortable or surprising. Furthermore, Shinji and Tadashi's stories provide examples of Japanese people using two different expressions: omote: tatemae [front] and ura: honne [back]. This may indicate that Japanese people tend to maintain their tatemae more often in public, especially when they talk to strangers.

\subsubsection{Differences in Attitude and Stance for Different Types of Interlocutor}

There is a similarity between the U.S. and Japanese participants with regard to differences in attitude when talking with friends or strangers. I asked the following questions:

(6) How are your attitude and stance different when talking to friends and when talking to strangers? (友達と会話をするときと見知らぬ人と会話をするときと OOさんの接し方の何が違うと思いますか。) 
Marc said about his talks with friends that, "You don't usually think what is allowed or what is not allowed, it's pretty intuitive; you don't have to worry about saying something that might offend them, so you don't pay attention to social rules of interaction.”

Similarly, Kazu, a Japanese participant, stated that he does not tease anyone if he and the other person do not have an intimate relationship; he said, "If I tease a stranger, and they get upset, I don't want that kind of thing, I need to feel intimacy before I make fun of someone." Shinji said he often does touch his friends' bodies. Both the U.S. and Japanese pairs mentioned that the way they tease and make jokes requires a different attitude from that used for small talk with strangers. Both groups stated that they only tease and joke with their friends.

As for their talks with strangers, Kenji said he, "Smiles, laughs excessively." Jiro said, "I communicate with strangers empathically [kyookan]." Sebastian said, "I tend to look at the intent, I am more diplomatic.” Wayne said, "Best behavior.” Marc said, "Formal code, decent behavior." These statements show that both the U.S. and Japanese participants are aware of differences in distance and intimacy levels, and that they use different communication styles when talking to friends and when talking to strangers. Sebastian said, "There always seemed to be intent." Wayne said "There is definitely a lot more distance. I am on my best behavior when I am talking to strangers, usually.” Likewise, Jiro and Hiroshi said, "I will be considerate [ki o tukaimasu], in order for strangers not to think I am a bad person." This means that he wants strangers to feel that he is a decent person. Overall, the responses of the U.S. and Japanese participants imply that both cultures have a certain degree of formality when talking to strangers. 


\subsubsection{Do Conversations with Strangers Happen Often?}

"Yes, all the time," "Several times a day!" "Absolutely!" These are the answers from the U.S. pairs. They anticipate conversation in public spaces, and talk about objects they own, sports, entertainment, news; they say that sometimes it leads to great conversations. Wayne mentioned that, "I never think, 'What the Hell is going on?' It's totally normal for me." Alcibiades said that, "When strangers start conversations, they begin with a compliment; that way, the initiator can get attention to talk about ME!" $\mathrm{He}$ stated that people talk for their own sake, to open up an opportunity for self-centered conversation. Franck also mentioned that English speakers sometimes exchange thoughts, share information and ask genuine questions during small talk.

The Japanese participants said "No," "Not so much"; they have this type of conversation with strangers "Only on special occasions." One participant said, "If it happens [talking to strangers], it should be only for asking directions or shops." I persisted with these questions, and they eventually said that places to drink, especially Izakaya (Japanese-style bars) may be a place where conversation with strangers may and can take place. Hiroshi mentioned that "When I am in a Japanese-style bar, I become friends with strangers very easily." Shin said that "Nomikai (drinking party) definitely leads me to talk to complete strangers in everyday life." 


\section{CHAPTER 4: DISCUSSION}

In the previous chapter, I showed the findings from the unmonitored pre-interview observation and the interview about small talk. In this chapter, based on these findings, I will discuss how the U.S. and Japanese participants view small talk, and discuss perceptions of small talk, in order to compare social norms and values associated with small talk between the U.S. and Japan. I will also discuss small talk by using the ideas of Barnlund's public self and private self, and Lebra' uchi and soto, honne and tatemae, and ura and omote.

\subsection{The Unmonitored Pre-Interview Conversation}

\subsubsection{Topics Participants Discussed}

I divided the topics into five categories: 'research-related,' 'basic information about self,' 'factual information,' 'living in the U.S.,' and 'personal concerns.' Both the U.S. and Japanese participants talked about 'research-related' and 'basic information about self,' but the use of 'factual information' and 'personal concerns' are different. The U.S. participants often talked about 'factual information', while the Japanese often discussed 'personal concerns.' Both groups exchanged information when talking to strangers, but the type of information exchanged differed: the U.S. pairs focused heavily on exchanging impersonal information (Informational Talk) while the Japanese pairs shared personal concerns (Personal Informational Talk). Although both groups implemented small talk in a culturally appropriate way, the Japanese males could not maintain a smooth flow in their small talk. While the U.S. groups talked about factual information, developing in-depth treatments of topics, the Japanese groups may have 
been more cautious, and took time to feel out each others' true characteristics/personality by asking surface-level questions. This caution might have been a result of the personal nature of the topics they discussed. It may also be an indication that the Japanese may have less experience with small talk.

The difference in topic choice between the U.S. and Japanese male participants parallels with Tannen's definition of the terms "rapport-talk" and "report-talk." Tannen (1991) claims that women and men have different ways of talking; she says, "For girls, talk is the glue that holds relationships together. Boys' relationships are held together primarily b activities: doing things together, or talking about activities such as sports y or, later, politics" (p.85). The Japanese male participants in my study may have been trying to establish relationship, or to get to know each other by exchanging personal information. Tannen (1991) also states that, “The men's style is more literally focused on the message level of talk, while the women's is focused on the relationship or metamessage level" (p.142). At the first glance, it is tempting to say that the differences in communication style between the U.S. and Japanese are similar to the differences in conversation style between men and women. However, we are reminded of Wetzel's (1988) argument that to understand this phenomenon it is necessary to understand the "locus of power" in each culture, and how that differs for the U.S. and Japanese participants. There is room for further research into power and small talk. Furthermore, as I selected only male participants, it is necessary to study female-female small talk in order to better understand differences in real-world language use.

Additionally, 'to talk' may have different meanings for the two groups. Japanese people are familiar with the proverbs related to talk, such as "Kuchi wa wazawai no moto 
[the mouth is the source of calamity]," "Tori mo nakaneba utaremaji [If the bird had not sung, it would not have been shot]" and "Kuchi ni mitsu ari, hara ni ken ari [Honey in the mouth, a dagger in the belly]" (Yamada, 1997, p.17). These proverbs imply that excess talk is unwise and harmful. On the other hand, the English terms "eloquent," "articulate," and "coherent," ascribe positive connotations to talk. Further research into the nature of talk itself may help to explain the difference in small talk between the U.S. and Japan.

Presenting topics differently relates to Barlund's idea of the differences in the size of 'private self' and 'public self' between the American and the Japanese. One of Barnlund's (1975) findings was that his Japanese participants “...communicate less of themselves verbally and prefer a lower degree of personal involvement" (p.35), while the Americans “...communicate their views more and on a more personal level across a variety of topics" (p.37). My study, however, showed the opposite. In my small talk setting, the U.S. participants discussed their classes and the content of their school work quite deeply, exchanging a lot of information with each other. The Japanese pairs, on the other hand, discussed topics related to personal matters, and described these matters comprehensively. This may show that while the U.S. participants tended to stay away from private information, the Japanese pairs preferred a higher degree of personal involvement. It should be noted that, although the Japanese pairs exchanged personal information right from the very beginning of their small talk, the type and depth of personal information shared changed gradually over the ten-minute conversation. This may show that the interlocutors progressively increased their understanding of one 
another as if they were exchanging personal resumes, and eventually aggregated enough personal information to openly discuss personal concerns.

In terms of Lebra's situational domains framework, the Japanese small talk started as a ritual situation, in which the Japanese male participants were strangers and perceived themselves as they were in public. After the Japanese male gradually exchanged personal information (for example, briefly examining personal information about each other, such as who he is, what he knows about, what are we are alike or different), they began to exchange personal concerns. After getting to know about each other, it was not a fully ritual situation; the situation was comfortable enough to exchange personal information. On the other hand, the U.S. male's stance and choice of conversation topics may not change from the beginning of the small talk to the end.

For the U.S. males, 'living in the U.S.' was not a talk-worthy topic, because it is their home country. This defect in my data suggests further research on small talk. What if the small talk study were conducted in Japan, with U.S. natives? Would the U.S. participants talk about 'living in Japan' and eventually move on to discuss personal issues or worries, or would the English-speakers maintain informational-only conversation? Also, it would be interesting to know whether Japanese participants in Japan would conduct informational talk, or whether they would talk about personal concerns as was found in this study.

One striking characteristic in the Japanese males' small talk was that they discussed the topics of 'age' and 'status.' Many scholars have highlighted that Japanese people require a hierarchical system in order to act properly, and that they are comfortable when they know their proper place, position, or rank with regard to other 
members; a social group is the key to self-identify and knowing where you are (Watanabe, 1993; Matsumoto, 1988; Lebra, 1976). The Japanese participants in this study paid attention to 'age' and 'status' but the U.S. participants made no mention of 'age' or 'status.' Some Japanese participants asked direct questions about age, year in school, or affiliation. It seemed that, since the Japanese participants have been in the U.S. for some time, they feel that being "regular students" is high-status compared to being IELP students or exchange students. These kinds of information, such as length of time spent in the U.S. and enrollment status (regular, exchange, or IELP), may have created a basis on which new hierarchical relationships were formed. Of course, it is not clear what the Japanese male participants actually feel about status in the U.S.; however, they discussed enrollment status and adjustments to the U.S. life style such as getting along with native English-speakers, and how widely expanded their personal networks have become in the U.S. These considerations may indicate that a new structure of relationships may have formed, because since life in the U.S. is so different from life in Japan, new vertical relationships along the lines of enrollment status, English-language ability and degree of adjustment to the lifestyle change have to be established. For example, a regular program status might be higher than an enrollment in an English language program, or a newlyarrived student's status may be lower than that of a student who has been in the U.S. for a year because more of U.S. society is accessible to him. Therefore, even though the Japanese male participants follow conventional relationship patterns, such as asking about 'age,' other metrics become important. Hierarchical relationships may be regenerated outside of Japan. Future research on how relationships are formed outside of a conventional social network established in Japan is required. 


\subsubsection{How Participants Use the Pause or Silence}

I counted the frequency of pauses that were three seconds or longer in the preinterview small talk and compared the two groups. These pauses appeared more frequently in Japanese conversation, and the longest pause or silence was 34 seconds in Japanese and 8 seconds in English conversation. According to Jaworski (2000), even though small talk and silence are universal, how they are used or tolerated differs depending on culture (p.114). More importantly, the previous research does not address the Japanese attitude towards silences that do not have a specific intention or illocutionary force such as rejection and declining. Previous research was focused on the use of silence in business meetings (Nakane, 1970; Yamada, 1992) and interpretation of silence in arts and movies (Mizutani (1979) cited in Yamada, 1992). How people actually deal with silence in an on-going interaction remains an open question.

Many scholars have researched the use of silence in business meetings (Nakane, 1970; Yamada, 1992). Yamada (1992) writes, "Japanese prefer the interactional mode of silence because of the belief that silence best preserves the wa (harmony) of the group" (p.38). Yamada cites Mizutani's (1979) research and mentions that, “there are comparative studies that indirectly refer to the American preference for, and the Japanese distrust of, talk (cited in Yamada, 1992, p.36). Mizutani compared a scene from an original Japanese movie and the adapted American western, and he states that "...for Japanese, silence in context is meaningful and valued" (cited in Yamada, 1992, p.36). These silences have purposes, meanings and proper usage; however, the small talk setting in my study is not a business meeting or the asking of a huge favor. This is a situation where the participants met for the first time while waiting for a group interview to begin. 
In other words, this is analogous to the first meeting between clients and business partners. During small talk, both groups of participants felt silences that were uncomfortable or awkward; therefore, both groups of participants attempted to fill the pauses by returning frequently to the same topics and repeating topics. The result that both groups of participants felt silence undesirable indicates that it is necessary to study silence in an on-going interaction to better understand small talk interaction in both countries. Unfortunately, this small talk study has not answered the question of how the participants actually thought about silence which gives further impetus to future research on the nexus of small talk and silence.

\subsubsection{Loop Sequence in Small Talk}

While the English-speaking pairs demonstrated the loop sequence only once, the Japanese pairs' small talk contained loop sequences eight times. In other words, the turntaking rule differs between the U.S. and the Japanese participants. Metaphorically, turntaking is playing tennis: the U.S. pairs continue to rally until either one fails. After one player fails, either the other player may throw a ball or the first player may quickly pick up a ball and continue the rally. The Japanese pairs, on the other hand, chat reciprocally, like tennis players at practice standing abreast and hitting balls into a wall. After the first player fails, it often does not directly affect the other player because s/he has another ball. When the first player hits a ball, it may not come back directly toward the second player; that player may choose to hit it back or to use his own ball and start the rally again. This metaphorical turn-taking is in agreement with Iwasaki's (1997) loop sequence. Even though the small talk in this study did not occur in a storytelling setting as it did in Iwasaki's research, the loop sequence still appeared in participants' conversations (only 
once in the U.S. small talk, and eight times in the Japanese). Iwasaki (1997:690) concluded that employing the loop sequence is a mutually-understandable way indicating cooperation and sensitivity, which is related to the Japanese notion of "mutual dependency." The term "mutual dependency" may have a negative connotation in English, but I would like to emphasize that this mutual dependency is related to the concept of $w a$ (harmony). The Japanese male participants in my study may be showing sensitivity to understanding the other interlocutor through the loop-sequence.

\subsubsection{Noncommittal Remarks}

This study also shows that Japanese participants used a wide variety of "noncommittal remarks." As I explained in Chapter 3, these "noncommittal remarks" may be one characteristic of Japanese conversational style in small talk. To continue the tennis metaphor, "noncommittal remarks" are like the balls. The first player hits a ball blindly without specifying any direction, and the ball comes back to a very ambiguous area where either the first or the second player can hit, or the ball may bounce back and roll on the ground. This style of turn-taking is dissimilar to the U.S. style.

I found in my data that the use of "noncommittal remarks" happens often in Japanese conversations; therefore, I claim that the skill of issuing and dealing with noncommittal remarks is a way to show sensitivity to the other's feelings and that this skill is required for smooth Japanese interaction and may be a key component of Japanese conversation. Lebra (1976) explains that omoiyari (empathy) "refers to the ability and willingness to feel what others are feeling, to vicariously experience the pleasure or pain that they are undergoing, and to help them satisfy their wishes" (p.38). She also states that, "In conversation the speaker does not complete a sentence but leaves it open-ended 
in such a way that the listener will take it over before the former clearly express his will or opinion" (p.38). These "noncommittal remarks" may provide an opportunity to depend on the other's thought (omoiyari) to choose whatever action the receiver of the noncommittal remark feels appropriate. Omoiyari on the part of the receiver of noncommittal remarks may mean to guess what kinds of messages are hidden in the remarks. Omoiyari on the part of the speaker of noncommittal remarks may mean to show his or her understanding of what preceding conversations had meant, or it may be a counter for awkward silence between strangers. Understanding the notion of omoiyari may be essential to conducting Japanese conversation in a culturally appropriate manner.

\subsection{The Interview}

\subsubsection{Different Views on Small Talk}

The most prominent result from the interview is that interactions with strangers are completely normal for the U.S. participants, while for the Japanese participants such interaction makes them uncomfortable. Barnlund brings up the idea of different concepts of self (public self and private self) between Americans and Japanese: One of Barnlund's conclusions is that in Japanese interpersonal communication a speaker "[usually] interacts more selectively and with fewer persons" while the Americans' "[usually] communicate with a larger number of persons and less selectively" (Barnlund, 1975, p.34-36). These findings parallel the findings in my study; when I asked my participants about the circumstances in which they interact with strangers, the U.S. participants reported that they are more likely to interact with strangers in everyday life, while the Japanese participants could not easily come up with times or situations in which they talked to strangers. 
Most of the U.S. participants mentioned that they felt comfortable talking to strangers every day. One relevant study here might be Bailey's study (2009) about the difference in expectations about interaction in service encounter between immigrant Korean business owners and African-American customers. Immigrant Koreans interacted with customers only with a greeting or service-related language (socially minimal exchange), while African-Americans tended to be enthusiastic about personal interaction in service encounters (socially expanded exchange). Bailey states that there are significant differences in how different cultures communicate respect in service encounters. In my interview on small talk, the U.S. participants gave examples showing that talk governs the management of service encounters interactions. In service encounters, they may talk about a box of cereal or some product in front of them in order to communicate respectfully. Furthermore, the U.S. participants tended to have a more negative view of bus stop conversations with strangers than they had of conversations in a doctor's waiting room. The Japanese participants did not recognize a difference between these two types of locations, which implies that the U.S. participants are more experienced in everyday small talk.

However, when I asked the question with regarded to the kind of topic ("Do you find it easy to discuss intimate things because you are talking with a stranger, someone you know you will never see again?”) three out of the eight Japanese participants said "Yes," while the most of the U.S. participants said "No." Only Sebastian said, "No, maybe yes.” He said, "I am comfortable talking about almost anything; I prefer not to discuss these topics, but I am probably comfortable doing this." Sebastian's case may be an exception as he admittedly said, "I am unique in this case." Alcibiades mentioned that 
he had experienced a man telling what he perceived to be private stories to a stranger on a plane. Alcibiades felt that he did not want to be like this man. Clear-cut division of topics in small talk between personal and impersonal subjects may indicate that the U.S. participants are more experienced in everyday small talk on impersonal informational topics. Even though the U.S. participants are more experienced in everyday small talk, they are more conscious about exposing personal information, and freely discuss impersonal information instead.

Additionally, "pointing-out" similarities in order to start a conversation may indicate a desire for connection or experience-sharing aligned with a comfortable attitude towards small talk. Small talk may be one key to showing respect and communicating appropriately in the U.S. On the other hand, the Japanese views of small talk may rely heavily on more restricted situations and interlocutors.

The Japanese participants reported that talking to strangers is an unusual thing to do, that they occasionally engage in small talk, but they are unfamiliar with the U.S. notion of small talk with strangers as a routine activity that happens in one's normal life. For this reason, the Japanese participants report that, when it happens, small talk with strangers is surprising and uncomfortable. This seems to be the reaction commonly shared among Japanese. Kenji said during the interview, "I will react to them naturally but I feel it's annoying," and Shinji said, "I would worry if something [bad] happens." The Japanese participants often had experienced a bizarre feeling when talking to strangers; however, instead of refusing to engage in small talk, they try to project a "positive face" by presenting themselves as decent and appropriate Japanese men. In other words, they do not want people to feel that they are impolite or rude. 


\subsubsection{Similar Views on Small Talk}

The interview revealed that both groups strive to be polite during small talk; Shin mentioned, "It is uncomfortable for me to not have conversations with strangers; my friends are different, I don't care if I talk or not." Hiroshi said, "I want them to feel that I am a decent man," while Kazu added, "When I am with strangers, I tend to create my own tatemae [what one says on the surface].” Sebastian, an English-speaking participant, agreed to feeling the need to be polite during small talk, saying, "[I] try to be more sensitive about, I don’t want to say something weird.” Kramer said, “[I] try to control what others think about me," while Marc says he "uses formal code, and decent behavior." Frank told me that he tries to be "pretty diplomatic in public." These statements show that most of the participants in my study are aware of 'face,' and strive to behave properly in small talk settings with strangers.

\subsubsection{The Japanese Participant's Views on Small Talk}

The Japanese males acknowledged that talking to strangers in public violates Japanese cultural norms. They may engage in small talk because of tatemae (what one says on the surface; the Japanese way to be polite), but because their honne (one's real intention) is different they may show ambivalence. According to Lebra's three situational domains, talking to strangers is in a ritual situation (soto and omote) such as service encounters or on public transportation, the interactions often have a prescribed exchange which does not allow much deviation. In anomic situations Japanese people can afford to be rude or shameless according to Lebra. As in the examples of talking to strangers provided by Kenji and Tadashi, they politely engaged in small talk with a stranger, but it is possible that the Japanese people can be rude or behave shamelessly when they have 
small talk with a stranger. On the other hand, a ritual situation in small talk may quickly become intimate, if the interlocutors discover each other's characteristics. Once they know each other well enough through exchanging personal questions, the small talk may become less ritual and more intimate. My small talk data shows that the Japanese male participants gradually exchanged personal concerns after which the small talk situation changed from a ritual situation to an intimate situation.

\subsubsection{Japanese Small Talk Sometimes Happens}

During the interview, most of the Japanese participants mentioned that talking to strangers may happen at a bar. Most of them agreed that they are more likely to talk at the bar, or more likely to become friends with a stranger easily. This shows the Japanese conversation is regulated by situation and setting. Nomikai (drinking party) and gokon (matchmaking party with the opposite gender) were examples of small-talk settings given by the Japanese participants during the interview. Nomikai and gokon are different from small talk setting, because nomikai (drinking party) is a potentially intimate situation in which the members are expected to be friends or, at least, the purpose of these social gathering is getting know each other. Before the members meet each other, they have agreed to meet new people at a defined place. At the beginning, the members of the party may be interacting in a ritual situation if they are strangers, but drinking may accelerate the pace at which the situation becomes intimate. Likewise, nomikai situations can be anomic; for example, a person who came late to the drinking party may find that members of the group seem to have a different level of inebriation. The person's behavior - his/her choice whether to drink and play "catch up" or to remain somewhat aloof — will be determined by his/her perceptions of the situation. 
The Japanese participants had small talk experiences in both public transit and at special events such as conferences, music concerts, and places where it is common to talk with strangers, but they are unfamiliar with the U.S. notion of small talk as a ritual norm. Japanese people, however, may engage in small talk if the time and place are appropriate, like in nomikai.

These concretely-defined places are indispensable because Japanese people rarely talk to strangers; when one of these venues presents the right time and place, they talk openly and exchange personal information, and the situation becomes an intimate situation. Intimate situations involving drinking may be the key to communicating with strangers in Japan.

The U.S. small talk may happen everyday and almost everywhere, and the topics discussed are often impersonal. In Japan, on the other hand, small talk may happen occasionally, and concretely-defined settings are necessary because the topics discussed (and thus the situations) are often potentially intimate. All in all, small talk in each culture is a reflection of some aspects of culture's social norms.

\subsection{Limited Data Collection}

In this study, there were three English-speaking pairs and four Japanese pairs; therefore it is difficult to generalize about the broader population. The Japanese males in this study were students who had been in the U.S. for less than two years. They were not in their home county; if I had researched 'small talk' in Japan, they may not have talked about living in a foreign country or even living in Japan. In this sense, the topics may not exactly be comparable between the U.S. and Japanese males. Also, while I did not study generational differences, they may play a role in small talk. Observation of nodding, 
facial expressions, and body gestures is missing from this study. Moreover, the participants were aware of the recorder when they were engaging in small talk; therefore, it may have affected their conversations. Furthermore, I strove to create a setting similar to real life, such as "waiting" for something like a job interview, but the setting might have been unusual for the participants. This study may not be representative of all the males, nor women, nor the broader U.S. and Japanese populations. 


\section{CHAPTER 5: \\ CONCLUSION}

This paper attempted to understand the differences in small talk between two different cultures. For this paper, based on the characterization of 'small talk' found in the literature, I defined small talk as:

Small talk is a sociolinguistic term referring to informal talk whose main purpose is mere socialization without a practical purpose. Small talk frequently happens in everyday life as well as during transactional interactions. It may happen between anyone; friends, family members, colleagues, acquaintances, teachers and students, customers and cashiers, and strangers. The function of and conventions about small talk vary by culture.

I have compared the male small talk, how native English and Japanese male speakers interact in small talk that occurs during the initial phase of relationship formation. In this small talk situation, participants who have just met are waiting for a group interview. The data on interaction during small talk come from the unmonitored pre-interview conversations between two participants, while the data on perceptions about small talk come from the interview. The overall result indicates that the U.S. and Japanese participants' use of topic, topic length, and frequency of pauses longer than three seconds are different. For instance, the average English conversation had 6 pauses or silences, and the average Japanese conversation had 16. However, both groups felt that silence in small talk is uncomfortable and awkward; therefore, the participants attempted to fill the pauses by returning frequently to the same topics and repeating topics. Both groups also discussed topics on which they shared knowledge, or discussed the research study in which they were participating. 
Another difference is the kinds of topics they spent time talking. The U.S. pairs engaged in "informational talk," where they elaborated on certain courses such as professors, systems, materials, or class content. The Japanese pairs, on the other hand, engaged in "personal informational talk," that is, talking about personal matters such as study problems, worries, gossip, and stories.

The results of the interview indicated that the U.S. participants have numerous experiences with and are aware of the small talk occurring in everyday life, while for the Japanese small talk with strangers is rare. The U.S. participants often felt comfortable or easy talking to strangers, while the Japanese participants felt uncomfortable and surprised. This difference in views of small talk with strangers suggests one possible source of cross-cultural miscommunication. My study suggests that U.S. males commonly discuss impersonal subjects; their talks tend to be about factual information. Japanese males, on the other hand, do not easily talk with strangers; they need a defined place or reason to talk in order to converse openly and exchange personal information. However, once they start small talk, they may talk about personal concerns and/or gossip. In addition, situations involving drinking may promote easy communication with strangers in Japan. This study has shown that small talk can be viewed as a locus where cultural differences in social norms are reflected.

Such differences in social norms for small talk between the U.S. and Japan might be perplexing and difficult for both English- and Japanese language learners. For instance English learners may need to be aware that public small talk happens often in the U.S., and also choose their topics appropriately. If they discuss items with which they identify (apparel, sports teams, hometowns), they may engage in a good (albeit momentary) 
conversation. Japanese learners of English may benefit by practicing small talk focusing on informational talk. Furthermore, Japanese learners of English may want to minimize the pauses in their small talk conversations, and teacher might want to encourage them to ask follow-up questions about impersonal topic. These practices will not only allow the student to perform culturally-appropriate English, but will also teach them that small talk is an essential component to polite behavior in the U.S.

Similarly, Japanese language learners in the U.S. may want to be conscious that public talk is conducted differently in Japan. Talking about personal concerns or sharing worries may, at the certain level, help build relationships with Japanese people, but the students should be aware that there is a defined time and place to conduct small talk is required in order to share the wa (harmony) and omoiyari (empathy). In Japanese language classrooms, teachers can help students model small talk situations in which they practice discussing personal matters respectfully, and encourage them to ask about affiliation (in order to better understand the other interlocutor). The training should also focus heavily on where such talks are appropriate. The appropriate situations will be those where members have gathered for the shared purpose of social interaction. Setting these practice talks in Japanese-style bars may be a suitable way to learn public communication skills with both friends and strangers.

Learning how to use "noncommittal remarks" would be absolutely essential. To my knowledge, the notion of noncommittal remarks does not receive as important an emphasis in English conversations as it may in Japanese conversation; therefore, these utterances may confuse Japanese language learners and leave them unsure how to use and react to a noncommittal remark. However, "noncommittal remarks" lubricate Japanese 
conversation and smooth the flow within Japanese conversation. In other words, learning to make "noncommittal remarks" and to disregard/reply to "noncommittal remarks" is an essential part of Japanese language curriculum, especially for advanced students.

For example, how to react to "noncommittal remarks" is to show understanding or comprehension of what the speaker has just said. Guessing why the speaker mentions it and what message is conveyed in this remark may be an appropriate practice. It also is possible to teach about being sensitive to the other's feelings-omoiyari practice. Furthermore, it may be difficult for Japanese language learners to disregard these remarks especially because it may be considered rude to dismiss the interlocutor's remark in English conversations. Learning how to treat noncommittal remarks is a necessary skill in order to maintain the "flow" of a conversation.

Identifying the purpose of "noncommittal remarks" was beyond the scope of this paper. However, they are useful at the moment when the speaker is considering what topic to broach next, or desires to show what s/he was thinking in that split second. They may also be useful to "fill in" the awkward silence. Similar to receivers of "noncommittal remarks", if a student has not experienced omoiyari, it may also be difficult to learn how to express omoiyari. In this case, Japanese language learners can start learning backchannel behavior such as " $a$, sodesu ka [oh I see]," to indicate understanding of what the speaker has said. After mastering the use of backchannel behavior, the language learner could learn to deliver his or her thoughts and comments as soliloquy. Understanding such utterances is indispensable to understanding Japanese language in culture. 
I emphasize that social interaction cannot be categorized by only one theme, and that becoming highly sensitive to what people talk about, how and when they talk with strangers and how social interaction operates appropriately may be keys to understanding different social norms. This study may be a modest attempt to reveal different norms of interaction with strangers; however, the findings about small talk should illuminate the differences in ways in which U.S. and Japanese male speakers interact in small talk. I hope that this study will, at least, increase our own awareness of communication style, and how they work in other cultures in order to reduce cross-cultural misunderstandings, and empower the next crop of successful global communicators. 


\section{REFERENCES}

Barnlund, D.C. (1975). Public and Private Self in Japan and the United States:

Communicative Styles of Two Cultures. Tokyo: Simul Press.

Basso, K. H. (1970). "To Give up on Words": Silence in Western Apache

Culture. Southwestern Journal of Anthropology, 26, 3, 213-230.

Blum-Kulka, S. (2000). 'Gossipy Events at family Dinners: Negotiating Sociability, Presence and the Moral Order' in J. Coupland (ed.) Small Talk, pp.213-40. London: Longman.

Brown, P., \& Levinson, S. C. (1987). Politeness: Some universals in language usage. Cambridge: Cambridge University Press.

Cook, H.M. (1998b). "Construction of speech styles: The case of the Japanese naked plain form.” Japanese Applied Linguistics, pp.80-108.

Coupland, J., Coupland, N., \& Robinson, J. D. (1992). "How are you?”: Negotiating phatic communion. Language in Society, 21, 2.

Coupland, J. (2000). Small talk. Harlow, England: Longman.

Coupland, J. (2003). Small Talk: Social Functions. Research on Language and Social Interaction. 36.1.

Drew, Paul, and John Heritage. (Eds.) (1992). Talk at Work: Interaction in Institutional Settings. Cambridge: Cambridge University Press.

Furuta, T. (1991). Obunsha hyojun kokugo jiten. Tokyo: Obunsha.

Hasegawa, T., \& Gudykunst, W. B. (1998). Silence in Japan and the United States. Journal of Cross-Cultural Psychology, 29, 5, 668.

Ide, S. (1982). Japanese sociolinguistics politeness and women's language. Lingua, 57, 357-385.

Iwasaki, S. (1997). The Northridge earthquake conversation: The floor structure and the 'loop' sequence in Japanese conversation. Journal of Pragmatics, 28, 6, 661.

Jaworski, A. (2000). Silence and Small Talk. In Justine Coupland (Eds.), Small Talk 11032. England: Pearson Education.

Jaworski, A. (1993). The power of silence: Social and pragmatic perspectives. Newbury Park, Calif: Sage. 
Katsuta, H. (2012). The Role of Compliment Topics in Compliment Response.

Jorden, E. H., \& Noda, M. (1987). Japanese: The spoken language. New Haven: Yale University Press.

Lebra, T.S., \& Lebra, W. P. (1974). Japanese culture and behavior. Honolulu: University Press of Hawaii.

Li, L. (2000). Nihongo bogo washa no zatsudan ni okeru monogatari no kenkyu: Kaiwa kanri no kanten kara. Tokyo: Kuroshio Shuppan.

Malinowski, B.(1923). The problem of meaning in primitive language. Supplement to C.K. Ogden \& I. A. Richards, The meaning of meaning. London: Routledge and Kegan Paul. 146-52.

Malinowski, B.(1972). Phatic communion. In J. Laver\& S. Hutcheson (Eds.), Communication in face-to-face interaction. Harmondsworth: Penguin. 146-52.

Matsuda, F. (1998). Nichijyo danwa ni okeru hanpuku hyogen no kinou ni kansuru kousatu. Ochanomizu University, nihongo bunkagaku kenkyujyo. 58-69.

Matsumoto, Y. (1988). Reexamination of the Universality of Face: Politeness Phenomena in Japanese. Journal of Pragmatics, 12, (4), 403-426.

Maynard, S. K. (1986). On back-channel behavior in Japanese and English casual conversation. Linguistics, 24, 6, 1079-1108.

Maynard, S. K. (1989). Japanese conversation: Self-contextualization through structure and interactional management. Norwood, N.J: Ablex Pub.

Misa, F. (2004). Silence during intercultural communication: A case study. Corporate Communications: an International Journal, 9, 4, 331-339.

Nakane, C. (1970). Japanese society. Berkeley: University of California Press.

Nakane, I. (2006). Silence and politeness in intercultural communication in university seminars. Journal of Pragmatics, 38, 11, 1811-1835.

Ogden, C. K., \& Richards, I. A. (1949). The meaning of meaning: A study of the influence of language upon thought and of the science of symbolism. London: Routledge \& Kegan Paul.

Ohama, R. (2006). Nihongo kaiwa ni okeru tan kotai to aizuchi ni kansuru kenkyu. Hiroshima-shi: Keisuisha. 
Ohama, R. (1995). Danwa bunseki zatudan wa ikani kousee sareruka. Hiroshima daigaku kyooikku gakubu.

Okamoto, S., \& Smith, J. S. S. (2004). Japanese language, gender, and ideology:

Cultural models and real people. New York: Oxford University Pres

Pullin, P. (2010). Small talk, rapport, and international communicative competence. Journal of Business Communication, 47, 4, 455-476.

Roberts, F., Margutti, P., \& Takano, S. (2011). Judgments Concerning the Valence of Inter-Turn Silence across Speakers of American English, Italian, and Japanese. Discourse Processes: a Multidisciplinary Journal, 48, 5, 331-354.

Sacks, H., Schegloff, E. A., \& Jefferson, G. (1974). A Simplest Systematics for the Organization of Turn-Taking for Conversation. Language, 50, 4, 696-735.

Saito, J., \& Postcolonial pragmatics. (2011). Managing confrontational situations: Japanese male superiors' interactional styles in directive discourse in the workplace.Journal of Pragmatics, 43, 6, 1689-1706.

Samovar, L. A., \& Porter, R. E. (1988). Intercultural communication: A reader. Belmont, CA: Wadsworth Pub. Co.

Smith, J. S. S. (1985). Japanese women's language. Orlando: Academic Press.

Smith, J. S. (1992). Women in charge: Politeness and directives in the speech of Japanese women. Language in Society, 21, 1.

Sturtz-Sreetharan, C. L. (2006). Gentlemanly gender? Japanese men's use of clause-final politeness in casual conversations. Journal of Sociolinguistics, 10, 1, 70-92.

Sturtz-Sreetharan, C. L. (2009). Ore and omae: Japanese men's uses of first- and secondperson pronouns. Pragmatics : Quarterly Publication of the International Pragmatics Association, 19, 2, 253.

Sukle, R. J. (1994). Uchi/soto: Choices in directive speech acts in Japanese. In J.

Bachnik and G. Quinn (Eds.), Situated meaning: Inside and outside Japanese self, society, and language. Princeton, NJ: Princeton University Press, pp.113-142.

Tanaka, H. (2006). Human Studies, Vol.22, No.2/4 Ethnomethodology and Conversation Analysis: East and West (Oct, 1999), pp.363-395 
Tannen, D. (1994). Talking from 9 to 5: How women's and men's conversational styles affect who gets heard, who gets credit, and what gets done at work. New York: W. Morrow.

Tannen, D. (1991). You just don't understand: Women and men in conversation. New York: Ballantine.

Yamada, H. (1997). Different games, different rules: Why Americans and Japanese misunderstand each other. New York: Oxford University Press.

Yamada, H. (1992). American and Japanese business discourse: A comparison of interactional styles. Norwood, N.J: Ablex Pub.

Watanabe, S. (1993). Cultural Differences in Framing: American and Japanese group Discussions. In Deborah Tannen (Eds.), Fraiming in Discouse 176-209. Oxford University Press.

Wetzel, P. J. (1988). Are "Powerless" Communication Strategies the Japanese Norm? Language in Society, 17, 4, 555-564. 


\title{
APPENDIX A: INFORMED CONSENT FORM
}

\author{
Cross-Cultural Communication in Group Interviews
}

Analysis of Communicative Behaviors of Native Speakers of English and Japanese

You are invited to participate in a research study conducted by Chie Furukawa from Portland State University, the department of World Languages and Literature. The researcher hopes to compare ways in which American and Japanese males communicate. In particular, the researcher hopes that through this comparison it will be possible to identify some tendencies in the communicative strategies of English and Japanese speakers. This study is being conducted in partial fulfillment of the requirements for a masters' degree, under the supervision of Dr. Suwako Watanabe of Department of World Languages and Literatures at Portland State University. You were selected as a possible participant in this study because you are native speaker of either Japanese or English.

If you decide to participate, you will be asked to participate in a group interview and fill out a survey. These activities will be recorded from the moment you enter the room until the moment you leave, using audio recorder OLYMPUS Voice-Trek V-41. The estimated length of time for the interview is from 30 minutes to 45 minutes. The risk to this study's participants are that it is possible that the amount of the time required and having oneself and his speech audio-recorded can be uncomfortable. Some people may be concerned that they may make mistakes. There is no right or wrong answer, you can take as long as time as you want to respond. It is important that you take part in the interview as naturally as possible.

Any information that is obtained in connection with this study and that can be linked to you or identify you will be kept confidential. The information you give me will be kept confidential to the extent permitted by law. Copies of the recordings, the transcriptions, and the consent forms will be kept in a secure locker in my house or in secure folders on my personal computer. When I report the findings of the study, I will use pseudonyms for any personal names, but some general demographic information such as gender and approximate age will not be changed.

Your participation is voluntary. You do not have to take part in this study, and it will not affect your course grade or your relationship with Portland State University or me. You may also withdraw from this study at any time without affecting your course grade or relationship with Portland State University or me.

If you have questions or concerns about your participation in this study, contact Chie Furukawa at 5706 North Maryland Ave Portland, OR 97217, (615) 877- 9112. If you have concerns about your rights as a research subject, please contact Research and Strategic Partnerships, Market Center Building 6th floor, Portland State University, (503) 725-4288.

Your signature indicates that you have read and understand the above information and agree to take part in this study. The researcher should provide you with a copy of this form for your own records.

Printed Name

Signature

Date 


\section{APPENDIX B: \\ Information Survey Questionnaire}

1. Sex: Male / Female / Self-Identified

2. Age: ( ) years old

3. Year in School: freshman / sophomore / junior / senior

4. Length of time living in the US: (

5. Work experience: part-time / full-time / intern

Job 1: Description of job

length of work experience( ) months

Job 2: Description of job part-time / full-time / intern

length of work experience( ) months

All personal information will remain confidential. 


\section{APPENDIX C: \\ Japanese Information Survey Questionnaire \\ 質問紙}

性別: 男性 - 女性

年齢: ( ) 歳

学年: 大学 1 年 · 2 年 · 3 年 · 4 年 ·その他 $(\quad)$

アメリカ在住期間：1ヶ月 - 3ヶ月 - 半年 ・ 1 年 - 1 年以上 ()

(1)仕事経験(アルバイトを含む) アルバイト ・ 正社員 ・ インターン

仕事内容

期間（）ヶ月

(2)仕事経験(アルバイトを含む) アルバイト · 正社員 ・ インターン

仕事内容

期間（）ヶ月

この質問紙は研究目的のみに使用され個人を特定することはありません。 


\section{APPENDIX D:}

Interview Questions

\begin{tabular}{|c|c|}
\hline 1 & $\begin{array}{l}\text { In what kinds of situations do you talk to complete strangers? (どんな状況で見知ら } \\
\text { ぬ人と話します?) } \\
\text { Follow- up question: Have you ever enjoyed or had a good time talking } \\
\text { with a stranger? If you have, please describe the circumstances and } \\
\text { situation. (今まで見知らぬ人と話して、楽しかった、いい会話をしたと } \\
\text { いう経験はありますか。もしあれば、どういう状況だったのか教えて } \\
\text { いただきたいんですけど。) }\end{array}$ \\
\hline 2 & $\begin{array}{l}\text { Usually we have everyday conversations with people we know, but there are } \\
\text { occasions when we have conversations with strangers. I mean actual conversation, } \\
\text { more than simple communication with a specific purpose, like asking for information } \\
\text { or the set exchanges that come with service encounters. What are typical situations in } \\
\text { which casual conversation can occur with strangers? (普段いろんな場面で人と話す } \\
\text { ことがあると思うんですけど、例えば、道をきいたりとか決まったあいさつを交わすと } \\
\text { かではなく、特別な理由ではなく、見知らぬ人と話す時はどんな時、どんな場面だと } \\
\text { 思いますか。) }\end{array}$ \\
\hline 3 & $\begin{array}{l}\text { Please think for a moment about the conversation topics you discuss with friends, but } \\
\text { which you probably would not discuss with strangers. What are some examples of } \\
\text { each? What topics are easiest to talk about with strangers, and what topics are off- } \\
\text { limits for discussion with strangers? (友達と話す内容を思い浮べてもらってもいいで } \\
\text { すか。その中で、たぶんそれは見知らぬ人とは話さないなと思う内容はどんなトピッ } \\
\text { クだと思いますか。また、どんなドツクが見知らぬ人と話しやすいですか。見知ら } \\
\text { ぬ人と話さないと思うトッピツクはどんなトビツクですか。) } \\
\text { Follow-up question: Do you ever talk about private issues with } \\
\text { strangers? (プライベートのことや自分のことについて話すことはあり } \\
\text { ます?) }\end{array}$ \\
\hline 4 & $\begin{array}{l}\text { Do you find it easy to discuss intimate things because you are talking with a stranger, } \\
\text { someone you know you will never see again? (見知らぬ人、もう二度と会わないとい } \\
\text { う人だからこそ、プライベートのことが話しやすいと思ったことはありますか。) }\end{array}$ \\
\hline 5 & $\begin{array}{l}\text { What if you are in a doctor’s waiting room or waiting for a bus? If a stranger suddenly } \\
\text { starts talking to you, what goes through your mind? (病院で自分が呼ばれるのを待 } \\
\text { ってる時やバス停でバスを待っている自分を想像してみてもらってもいですか。そ } \\
\text { のとき突然見知らぬ人が会話を始めてきたら゙う思いますか。OOさんのリアクショ } \\
\text { ンを教えてください。) } \\
\text { Follow-up question: What do you think when a stranger talks to you } \\
\text { without specific purpose (like asking for information or directions? (特 } \\
\text { 別な目的がなく話しかけられたら、どう思いますか。OOさんのリアク }\end{array}$ \\
\hline
\end{tabular}




\section{ションを教えてもらいたいんですけど。)}

6 How are your attitude and stance different when talking to friends and when talking to strangers? (友達と会話をするときと見知らぬ人と会話をするときと OOさんの接し方 の何が違うと思いますか。)

7 Do you think that conversations between strangers happen often in American/Japanese society? Please describe the most common circumstances and situation. (見知らぬ人と話すことは日本社会でよくあることだと思います？もしそう だとしたら、それはどういう状況だと思いますか。） 
A: Alcibiades B: Kramer

\section{APPENDIX E: English Small Talk Data [E-1]}

1:21 -1:34 Topic 1 (13sec)

B: so I didn't catch your name.

A: Alcibiades

1:35-3:12 Topic 1 (1m37sec: no count)

A: kono kyoono group korekarasuruyatu nishonngoto kannkei shiterunokana?

$<$ JAPANESE Conversation omitted $>$

$<$ Conversation omitted $>$

A: 2:48 you supposed to let participants know too much about what you are doing

B: Oh wow,

A: go home and read up and give answer they would have if they hadn't educated

themselves, or try to be something that it's not

B: Ok...ok I understand that.

A: humhum

(2 sec)

B: This--these are so good; I love matcha. Like this is so good.

A: humhum

(1)(6sec)

3:18-3:21 Topic 1 (3sec)

A: they are good. Yumm!

B: NA

(2) (4sec)

3:28-4:13 Topic 1 (45sec)

A: Right at lunch time, too; e got lucky.

B: hehe yayaya,

B: I am gonna try some of this

B: Oh is that shrimp, oh my gosh!

A: Shrimp and Pork (laugh)

A: I like the mellow flavor

B: I didn't want that shrimp

A: hummmm takatakatkaka (knok on the desk? Like music?) 3:54

A: Fork? Here we go.;;; Oh wait oh no no right here..

B: haha;;hmm;;wow;;spoon

A: spoon, they are pretty good for fried rice

B: yeah

(3)(5sec)

4:18-4:35 Topic 1 (17sec)

B: hum hum

A: This is like the foreign language room or something. European language room maybe.

B: maybe...4:26

A: Performers. Finnish, Finnish, performers???

B: humhum ;;;;; mnrf;lakjlre (filler)

(4)(5sec)

4:40-5:55 Topic 1 (15sec)

A: 4:40 Are you in umm Furukawa sensee's class?

B: Unfortunately, she's not teaching second year this term.

A: Umm

B: But she was teaching it last term and fall term

A: humhum 


\section{B: but I also had her couple of times for the first year4:55}

\section{A: NA}

(5)(5sec)

\section{5:00-7:13 Topic 1 (2m13sec)}

B: I like her teaching style, she challenges everybody, but like in a comfortable sense, so everything that you learned, like you're supposed to know for the day, she'll stretch it and make you think using that but the kind of thinking outside.

A: Really?

B: So.

A: Sounds like a good style

B: humhum, yeah it's....., like the teachers, like some of the teachers, they'll go over the stuff that, that you're supposed to go over it, it's kind of basic, I guess, ah...but like she really stretches it out. So she'll show you how you can use this with what you've already learned and like connect it all together. It's, it's very good but it's hard.

A: 5:44 Like, uh, sentence patterns in a bunch of different situations, and how to use it?

B: yeah yeah, and how you can like connect it with other sentences and stuff.

B 5:52 Ah- and she's very passionate about this, it's like--I--she wants us all to excel, like, and

when she sees that we don't;;; that;;;we uh;;; uh;;;;when she sees that we don't, she gets upset? ha

A:, oh really? I haven't heard that before.

B: yeah no like--uh well you've had her before, right?

A: No, I didn't take any of the classes or anything, I just I kind joined at the top and I wanted to get my degree because I already learned Japanese a long time ago.

B: Umhmm

A: And of course I am still learning but I don't have to take the, the, the lower classes I am just

taking the top level ones I haven't had a chance to

B: 6:47 ok, yeah yeah yeah when she sees that like we haven't, like we're not prepared

A: $\mathrm{mmhmm}$

B: haha, like her expressions are....

A: good

B: are really like, funny but they're serious and like

A: good

B: she'll look at us and she's like "areareareare?" haha I am like I am like "AHHHH kill me now."

A: yeah man, a lot of teachers just let us lie,

B: Unn

A:... come in

B: yeah,

A: I like I like it when they run a tight ship

B:yeahyeahyeahyeah

A: when you actually get in trouble from not doing your work

B: oh my gosh yeah...it pushes you

(6) (3sec)

7:16-11:19 Topic $2 \& 3(4 \mathrm{~m}$ 3sec: topic 2 (1m28sec), topic 3 (2m35sec))

A: Un hum

B: I mean uh with this language I need to be pushed

A: Oh yeah?

B: unhnn

A: Outside motivation?

B: yeah

A: Nobody else is gonna do it 
B: yeahyeah yeah and even my friends like are helping me learn Japanese, it's like they can, they can push me, but like;;;I I need I need more than that, I mean so I feel like the the the teachers' impression of me is is important.

A: yeah for sure.7:45 for suurreee. Eventually it's gonna have to come from you though

B: humm

A: 7:50 If you want to keep going with it

B: Huuh...

AIt's depending on how far you want to going with it

B: I'm gonna try to take 4 year in the in the fall. uhh...World Languages department took a

budget cut, and so I can't take third year over the summer. So I have to test out of it on my own.

A: Test out of third year?

B: yeah.8:10

A: for reading, and writing, and speaking and listening two separate classes? I did that last

term.;;; The test is a bear.

B: yeah, but basically I'm gonna be I'm gonna be taking the, the whole thing that shou kfl I guess I'm gonna be taking like three tests for each. So I'm assuming.. I'm assuming

A: $\quad$ plus two writing assignments.

B: Really?

A: un hum, they are short though just one page.

B: Oh okay okay. 8:35 That shouldn't be that bad.

A: I did three though

B: Okay,

A: I did one extra

B: Nice

A: that was not great

B: haha44

(2sec)

B: Writing is not my strength

A: Oh yeah?

B: but it helps me it helps me retain the vocabulary, like;;; like I love JSL I love the way it teaches me. But I just wish to

A: $\quad$ That's the textbook, right?

B: unhum, I wish they would move away from romaji, if it was all in Kana and Kanji, it would;;it'd be perfect. Because I would, I'd be able to look at the Kanji and then research it and see what it is means, 'cuz that's what I do a lot of the times, like I'll I'll look at the vocabulary that I have, and I'll, I'll write down the Kanji and for each kanji I'll, see like the English equivalent for it and so it, it helps me remember stuff.

A: for sure 9:27 yeah Instead of it's kind of like holding people back..

B:humm

A:not learning, 'cuz, in both reading recognition--and pronunciation probably!--

B:uhun yeah, it kind of confuses me sometimes

A: --and reading speed?--

B: yeah;;;maybe ..... but I like the way the book teaches me.47

(2sec)

B: 9:49some things, somethings aren't used anymore, but it's; it's just because the book's old

A: like what?

B: 9:57 Ahann, like we were learning about like old ways of speaking like (uhum) instead of saying TAKAI, you would say OTAKOOI

$A:$ Oh yeah that is very harikeck

B: haha

A: OHAYOUGOZAIMASU 
B: that's like the only one that survived, too, OHAYOUGOZAIMASU; and that's like

A: There's one more;;;there's one more;;;;;;;;;; OMEDETOU

B: OMEDETOU yeah yeah yeah yeah yeah. yeah that one survived but, but other than that they're, they're all wrong, but I like it 'cuz like if like one day wanna become like an actor;;; speak like samurai then haha(laugh) I don't know

A: un hun 10:35 you don't know how

B:it's good joke for my friends too. Like when I start speaking like a samurai, they all start laughing (laugh) haha (laugh)

(2sec)

B: 10:50 but I don't;; some of the vocabulary like SOBIETOJIN ;;;ike USSR

A: it says SORENJIN

B: it's SORENJIN or SOBIETO

A: 11:07 $\mathrm{OH}$ yeah, the non truncated words, that's right

B:11:10 Oh my goodness

(2sec)

A: they don't have any more of those ;;; no more SOREN

$B:$ ah yeah yeah yeah

(2sec)

B: Um (filler)

A: NA

(7)(3sec)

11:22 -12:40 Topic 3(1m18sec)

B: Kanji definitely helps like right now we are going over like the ummm (2sec) like vocabulary that you would use like a aaaa like at a train station or something so like ah kippuuriba kyuukouken Tokkyuken, and I can remember those words so much easier now because I look it the Kanji and it's like this means this this and

A: it's like the meaning is staring you right in the face

B: yeah

A: When you read it

B: Yeah yeah yeah

A: and you read it so much easier.

B: yeah yeah yeah

A: As long as you know it

B: Yeah

A: If you don't know it you are screwed

B: yeah

A: well not totally; you can guess

B: Yeah

A: You can make an educated guess and not know

B:hummmmhuhuhuh yeah

A: You can make an educated guess on the pronunciation and the meaning

B: yeah well some of them are just like so far out there, like you have like you have GAKUSEE;;;

but then like if you take that off and you just have GAKU and BU it's like MANABU. So it's like the really like you can get lucky sometimes, but...

A: that is not really that is pure guess work really because that is a like for a GAKUSEE that's two

Kanji right?

B:hum

A:two next each other ; then when there are two next to each other you know you will take the

Onyomi for both of them

B:wowow

A:just have one like MANABU just one Kanji then Kunyomi 


\section{B: NA}

(8)(3sec)

$12: 43-$

B: I never thought of it like that

A: yeah someone told me that when I was first studying kanji ?????

B: Holly carp

A:Dude;;yeah it really helps

B: whhaaaaaaaaaaaaaaaat?

A: Whenever you have multiple, use the "on", when you got a single, use the kun

B: Oh MY gosh that is crazy!

A:It'll help a LOT

B:yeah! yeah That makes sense, like ATARASHII or SHINBUNN

A: yeah ;;;yeah

B: Wow whaaaaat???

A: haha(laugh) haha(laugh)

B:my mind has been blown 13:03

A: haha(laugh)

B: Oh my gosh;; yeah

A: (laugh)

B: I think um like, they do they do get--

A: There are exceptions, though; very rare exceptions, BUT 95\% of the time that'll work

B: Yeah, they are, they're giving us a new like, they're giving us a new, um;; they're giving us a new um reading material. We're using um YOMIKAKUTYOO and uh, it basically has like each Kanji and then it'll use--it'll say like how this Kanji can be used like, like if you have a dansee or josee umm or jodann it'll have the kanji and it'll have different ways and then it'll have sentences, A: $\mathrm{mmhmm}$

B: ...using those kanji, and so

A: That helps a lot

B: It's really good, and it's tied to the book; you know how like a lot of things

A: Come In!

(13:57 Furukawa came in) 


\section{A: Sebastian\& B: Wayne \\ APPENDIX F: English Small Talk Data [E-2]}

1:20- 4:08 Topic1\&2(2m48sec: topic1 (58sec), topic2 (1m50sec))

$\mathrm{B}:$ Are you in the class?

A: No, not at all。

B: How did you ended up?

A: I have no idea.

$\mathrm{B}$ : randomly she

A: I know... there is like a mutual acquaintance and he asked me for it so I was like, alright, sure. Are you in the class?

B: No...

A: how did you get involved in this?

(2 sec)

B: I don't know...

A: you don't know?

B: what was I doing...maybe coffee hour?

A: Oh yeah?

B: You were in coffee hour?

A: I've never been there. I heard of it, I don't know what it is, though

B: Every Wednesday, today from 3:30 in the Smith. Smith second floor, they umm,, it's run by the international office.

A: is it for like speaking languages?

B: it's for anything, just go there... hang out, and interact,

A: 2:18 ah, are you um ....learning Japanese?

B: I study, I actually graduated last year but I still come here,

A: oh, yeah?

B: because all my friends are here.

A: hum

B: meet with them

A: at the coffee hour?

B: yeah;;; or make you know whatever make plans 2:37 hang out everybody wants to coffee hour A: yeah.

B: and Chie was ah friend of friend I guess,;; so he was going he, he went to Japan;; to work in a company, she was at the going away party? We talked there, we saw her again at coffee hour A: Do you know what she is studying? Like with her research project?

B: Not exactly, This thing is like a;; I think it's just talking about differences in conversation styles, for Japan--differences between Japan and American in conversation style maybe?

A: Hmm

B: I don't know...

A: Well

B: Wait are you studying Japanese?

A: No, (oh) well. I'm not studying any foreign language right now, at least formally at PSU, I was studying Chinese until last term, but I had a uhh conflict on my class schedule B: yeah.

A: so I registered one at PCC and that one got cancelled, I am just kind a waiting;; to take the 203 class either in the summer or next yeah.

B: you are going back and forth between PCC and here?

A: no 4:01 just for that one class, because I had to take one class during that same time period

B: Um

(1) $(4 \mathrm{sec})$

4:12-10:39 Topic2\&3\&1(6m27sec topic2 $1 \mathrm{~m} 41$ sec, topic3 4:29, topic1 $10 \mathrm{sec})$

A: it's definitely not the class, I wanna miss though, 203 
B: yeah

A: 'cause that's required for graduating (hahaha),

B: yeah

A: And that's the one class I can't take

$\mathrm{B}$ : what is your major?

A: uhhh Applied linguistics?

B: Applied linguistics

A: yeah

B: Do you know Mark? [Mark] Smith?

A: Mark Smith.....

B: I think he is in applied linguistics.

(2sec)

A: Mark! Yeah!! Is the tall?

B: yeah

A: and he just dyed his hair?

B:yeah

A:yeah I know Mark, yeah I like Mark, uh he's yeah he's in the applied linguistics program. 4:43

B: Yeah

B: And you have to have a lot of classes with Samantha Lester?

A: (laugh) huhuhuhuhu I don't have to but, yeah;;;

B: no but she's like--not the head, but--.....4:51

A: humhum

B: she's really high up the linguistics department, isn't she?

A:uhnnnnn yeah she's certainly been with the department for a long time 4:58 I think since like 89 or something, yeah I mean a really long time and ;;;she was a he;;;; ad of ;;;; the IELP program for a

number of years.???

B: really? 5:10

A: I believe...

B: Most of the people at the coffee hours are IELP

A: yeah, so I think she was like a head of the department when she first came for a long time, and then unnn, I don't know if she has ever been to the head of applied linguistics program. (?)

B: uhm

A: but she is probably in the top tier group

B: Yeah

A: How do you know Kim Brown?5:34

B: I ;;; I had a required class called the "understanding the international experience"

A: hunhun5:40

B:I had to take it when she was teaching.... I think she still teaches it now. She was teaching

then...5:46

A:so you are,...international...?

B: $\quad$ international studies;;;; major it was 5:52 East Asian studies

A: yeah

(2sec)

B: Ah.. Um yeah I took her class like a year and half ago(?);;;; I think

A: Did you like it?

B: yeah it was fun, it was kind a crazy, disorganized, they were still kind of working out likr;;; like how to how to actually conduct class.

A: I think that was an ongoing experiment.... (laugh) 6:17

B: yeah, so they are like tweaking the class while the class is going on;;;; and it had al these elements, there's like ;;it was all ::there is a lot of D2L stuff where um there's like two different there's like a mail box and a ; and a discussion page or whatever, there is two different ways to send the information, and we were using both for two separate types of assignments and all the stuff. A: yeah 
B: it was just kinda crazy and confusing but it's all like;; in class is all casual like discussion-based stuff

A: yeah 6:35

B: so that was really good but it's kinda chaotic ....

A:did you take the um;;;;;;; I had to take the class too, it is al so required for the TESOl certificate (?) B: yeah

A: ahnnn which I don't know why I am taking that but I got self involved in that somehow^ aaaaand (what do they call it?) the DDDD

B:Oh the the ummm like not personality test but ah;;

A: yeah it's ahh

B: your international

A: it's an inventory, yeah! 7:24 it's for like ah

B: yeah I tried to take it

A: DIA?? DIE?

B: I can't remember but something like that..

A: DOY? (Laugh)

B: you are you are international .....

A: IDI! Yeah

B: yeah something like that

A: yeah IDI international something inventory;;;; yeah I liked that thing 7:46

B: I was supposed to take it but ;; I could never get in, like my password and stuff

A: Oh really?

B: Yeah so I just, I forget, I tried like 4 times just to login

A: Oh that's sucks

B: and it never worked. And then they were like talking about it for the entire class period and I had no idea

A: yeah you had no connections to the

B:'cuz yeah it never worked. But I guess like

A: those were the nicest part of the classes, to me

$\mathrm{B}$ : We took it at the beginning and we took it again at the end

A: humhu.8:12

B: to see how like our perspective changes over the course

A: yeah8:19

B: or something and there was ;;;; I don't know there supposed be, not supposed be;; every class like a pretty average change, and our class was ;;really drastically different somehow-- I can't remember A: hum

B: or maybe our class was really drastic because it didn't change, I can't remember

A: haha(laugh) nobody moved? Oh some yeah it was interesting she said in our class that some people really move from ;;;ike say you're in maybe this is like made up but say you are in 8:53 60 percentile

B: huhum

A: In which they didn't have 60 percentiles on that test, but let's just say you're there...

B: yeah

A: that some people move forward

B: yeah

A: and then some people actually go the other way9:03 like they'll;;;;

B: yeah

A: have more of a

B: yeah depending on the?

A: stronger reactions ;;; like they'll take a step back before they take a step forward

B: yeah well they have that

A: yeah that chart

B: it's chat of like ;;; what stage you're at

A: yeah exactly 
B: international excer;;; acceptance.. .or whatever....

A: laugh

B: it's like the denial phase and then there's like the honeymoon phase, or whatever 9:27 like everything is great

A: yeah

B: You ignore the bad

A: there was like 6 stages, what were they?

B: I can't remember but...9:37

A: you are right, defense, minimization

B: yeah

A: Ahhn I know is it integrations, that's like where you want to be be,;; right?

B:;; I think so9:47 there is like

A: acceptance

B: yeah9:52

A: hmm we did that (soliloquy?)

(2sec)

A: you know, I can't remember (soliloquy?)

B: there is like a stage where you push away your own culture overly accepting of the other culture and there is a stage where like your pushing away the other culture

A: $\quad$ yeah

B: and pulling your own;;; and there is gets more balanced;; after that and those were the those might have been the stages that they were gauging like

A: yeah, it has to do with like ethnocentricity??

B: yeah

(2sec)

A:but yeah;; I am sorry I didn't get the idea that like that part of her test is her like going to get coffee

B: I think this

A: we are talking

B: I wander if she laughing

A: hahaha (laugh)

B: yeah

A: probably owaowa

B: HI (to the recorder)

(2) (4sec)

10:43 -11:17 Topic2 (34sec+@)

B: yeah...I know it, it was

A: so what do you doing with the;;;; international studies?

B: oh, I am moving to Japan next week.

A: Oh right!? That's awesome.

B: yeah

A: what are you gonna do?

B: teaching English. It is the best way the ;;;

A: with the JET?

B: No ... I wen't with that...11:01 minor company called the border link, a it is the same thing

A: humhu

B: less known they don't get quite deals jet kids, for the calle

11:17 Furukawa knock the door 


\section{A: Frank \&B: Marc}

\section{APPENDIX G: English Small Talk Data [E-3]}

9:36 -11:02 Topic $2 \& 1 \& 2(2 \mathrm{~m} 26 \mathrm{sec}$ : topic2 (25 sec), topic1 (28 sec), topic2 (33sec))

A: Marc, right?

B: Yeah, you're Frank?

A: yeah, I am Frank. So what do you do? 9:38 I mean, I mean obviously you are a student, I

guess?

B: humhum, I ah

A: what are you studying?

B: I'm studying development, international development

A: huhum

B: Ahmmm---- write for the Vanguard, I was actually

A: $\quad$ (over lap) which sections?

B: ah news

A: ok

B: yeah, ;;; 10:01 I was actually, I met her setting outside, reading

A: excuse me! (knockknock)

B: I was on my way to go try and harangue some people

A: huhun

B: and there were these two guys proselytizing on the park blocks,

A: huhum

B: and kind of a crowded area, so I sat down

A: was that last week, or...? or10:18

B: yeah

A: oh those guys, caused a bit of a commotion, huh?

B: yeah they did, and so I'm sitting there and watching them, doing my work, on my computer,

A: $\mathrm{mhmm}$

B: and she came up.10:29

A: uh yeah uh, a friend of mine writes for the Vanguard; Arts and Culture

B: Oh yeah?

A: ah Nick D'Emilio, you know him?

B: hmmhmm(no)

A: I know vanger is a pretty big staff. ;;;Yeah so yeah so I've been thinking of maybe try to get in there sometimes, 'cuz I do a little writing, too.

B: go for it. Do it !10:47 it's a fucking pain in the ass;;; it is so much;;;; there is so much to do. But it is so rewarding.

A: how long have you been writing for?

B: like a month

A: oh yeah?

B: I think. End of February,

A: hun

B: a little more than month.

A: NA

(1)(3sec)

11:05 -11:54 Topic 2(49sec)

B: what did you do?

A: a----n Japanese major so this makes perfect sense, right?

B: yeah, cool.

A: Umm yeah finished all my degree requirements already and, this month, doing .... I didn't do any like, "Freshman inquiry" or anything like that 
B: Oh yeah?

A: so I am doing all of them in this year, Capstone and Frank at the same time... pretty funny

(laugh)

B: yep yap huhuhu(laugh)

A: but ah.11:26;;;you know I'm a writer down for the Oregon university system (really?) On fourth Ave

B: really?

A: Um.. technical writing and copy editing, mostly $11: 38$

B:I see ;;; cus, I cover the legislature now--

A: Oh yeah?

B: --and OUS comes up a lot

A: hunhu, we have a ;;big, but shrinking budget

B: huuun

A: Rapidly shrinking

B: NA

(2)(3sec)

11:57 -15:34 Topic $2 \& 3(2 \mathrm{~m} 26 \mathrm{sec}$ : topic2 (2m50sec), topic3 (45sec)

A: but I work for pretty specific group within OUS, so I'm not

B: yeah

A: You know I know the people who are pretty high up but I don't interact with them very much

B: yeah

A: um

but;;;;; that's a lot of fun, I've been you know a private tutor for a while but I am sort of taking it easy, and when I say that I mean my main student graduated and is going to college and is not

taking it

B: hoho(laugh)

A:so12:20

B: So there you are...

A:NO problem with that though!12:23I got paid pretty well for it but I need some extra time because I've been doing, like past terms I was doing around 12 credits and this term and I did, I did 20 last term I'm doing 17 this term so; don't mind the break!

B: yeah 12:36

A: I've been surviving with on coffee. umm

B: tell me about it!

A: huhu (laugh)12:41you know but at the same time since I'm only, ONLY taking 16 this term I've decided I want to try to get in Vanguard if I can.

B: yeah!

A: umm---12:50

(2sec)

B: you did, you did 20? How many? 22? order?

A: hum ;;;;last term I did 20 credits while I was working

B: yeah so ;;; I think you'll be fine. 13:05

A: hunhun(laugh)

(2sec)

A: and ;;,;;;;You know my focus is Japanese literature

B: really?

A: specifically like poetry and that kind of stuff.

B: NA

(2sec)

A:I also I guess this is my hobby, you know I'm a bit of a gamer, as many people are

B: oh yeah? 
A: umm I play Dungeons and Dragons, so it's like unforgivably nerdy (laugh)

B: haha (laugh)13:32

A: but...

B: I'm afraid I can't talk to you anymore

A: It's ok haha(laugh)

B: (laugh)

A: I go for, go roll some dice of with my friends haha (laugh) a little bit it's great fun.

B: (laugh)

A:13:41 so what do you do?

B:13:43 I race bikes

A:I was gonna say you kind some reason, I got you pegged as a biker

B: yeah!

A: I don't know it was...I think I might have klsdghlke(talking to himself? 13:56)

B:NA

(2sec)

A: you race bikes, huh?

B: yeah

A: that's cool;;;;; like a, locally you mean go around get around for it?

B: huhum it;sfor PSU

A: oh really? I didn't know we had a team

$B$ : we have a racing team, we were actually talking about this

A: humhu

B: at our strategy for next year

A: humhu

B: that we talk to people, and they'll say, "Oh, whoa, I didn't even know we had a team"

A: huhum

B: Oh yeah;;;; but we're actually gonna win conference this year

A: Nice

B: We have one weekend left and there's pretty much--no--there's pretty much, I mean, short of high water, there's pretty much no way we're gonna lose.

A: huhum

B: so ....

A: Well great!

B: yeah So that'll be really cool. And last year, we had like one person on one podium 'cuz like we split up into categories; and all those sorts of things

A: huhu

B: but

A: well cool, that's good to hear

B: We're pretty much kicking ass, across the board 14:43

A: very cool

B :If I do say to myself

A: I'm gonna grab another one of these...they're yummy

(2sec)

B:14:49yeah

A: but ah---- (same time) what like, international development you said?

B: humhu

A: what like ah---do you specific;; focus on a specific region?

B: Africa

A: Africa?

B:I am just kind a token this I am doing this because my language is French

A: ok that makes sense.15:05 
B: I had to...yeah.. I had to tie some things together like that so

A: humhum,

B: I did that but I'm really interested in North Africa too

A: humhum

B: and Europe

(2sec)

A: Do you know anything about Chad? 'cuz I don't

B: not too terribly much, a

A: I know it's one of the French speaking countries though... 15:24

B: Chad is?

A: I think so it was French colony until...1970 I think.

B: really?

(3)(3sec)

15:37 -15:44 Topic 1 (7sec)

A: I am not going to take all it 'cuz I think Chie wants to eat some of it.

B: yeah but watch somebody else show up haha (laugh)

A: yeah (laugh)

(4)(3sec)

15:47 -15:57 Topic 1(indirect jorking? 3?) (10sec)

B: "You will be happy to know that food was good."

A: huhum (laugh with mouth full) "too good" 15:50

B: yeah;;;

A; "We're done; byebye"

B:hum;;

A:hum;;

(5)(8sec)

16:05 -16:57 Topic 1 (52sec)

A: so she just ran into you totally randomly huh?

B: huhum

A: cool!

B: yeah, until no her

A: she is the one of the Japanese instructors here

B: ah

A: but I never had her as a teacher, she's...Right 'cuz I was doing my.... when you have grad student instructors it's your first two years um,...and then you start interacting directly with professors

B: $\mathrm{mmhmm}$

A: and so, she wasn't here when I was doing it.;;but we still have kind of that student-teacher relationship, you know. She's never been my teacher!-

B: right

(2sec)

A: but she seems pretty pretty, pretty ah energetic, a lot of her students complain that she is too strict

B: Ooh! That's good.

A: but she's so nice to me.

B: haha (laugh)

A: so nice to us.16:53 Maybe 'cuz we're not students

B: probably

A: not students..

B: yeah 
(6) (3sec)

17:00 -17:12 Topic 2(12sec)

A:17:00 so how long you been studying French?

B: huummmmmmmum, ;;;;;since high school on and off

A: very cool

(7)(3sec)

B: haaaaaaaaaaaa

A: NA

(8)(3sec)

17:20 -19:38 Topic 3 (2m18sec+@)

B: my dream is to end up in uh ......you know... Tunisia, somewhere like that.

A: humhum

B: or Morocco. I'm not interested in Algeria for some reason.

A: I don't know much about the differences.

B: So, you've got Morocco, right? And then (ah-crist (talking to you))Algeria. Tunisia, Libya,

Ethiopia(knock knock knock)

A: humhu

B: right?17:43

A: Morocco, Algeria, Tunisia, were all French colonies

B: $\mathrm{mmhmm}$

A: Libya was an Italian colony (knock)

B: Egypt was an English colony (hit the table)

A: $\mathrm{mmhmm}$

B: so pretty much here over ;;; when all the decolonization started happening

A: huhm

B: 7:58France let go of Morocco and Tunisia first

A: cough

B: because they wanted to keep Algeria (knock knock) so they that long protracted war in Algeria 'cuz Fance decided to put all their ships in Algeria, ;;; Algerians saw it;; : recognized it;; I don't remember the, er, when they found their independence, later on, I think it--the late ' 60 's. 18:20

A: huhun

(2sec)

B: but there are lot of Burbur in Morocco. Tunisia is actually, I think, pretty narrowly ethnically homogeneous

B: which is interesting 18:32 They're, well,

A: wowou

B: mostly Muslim? so like 99\% Arab, 99\% Muslim, they're very--I guess in comparison to other Arab/Muslim countries--they're pretty relaxed, socially

A: umhm

B: you don't have you know the morals police going around, like you have in Iran or...probably some other places 18:52

A: Sounds kind of comparable to sort of Southeast Asia

B: does it?

A: well like the;;; like Indonesia for example and like Cambodia are mostly Islam as well

B: mmhmm, South Asia

A: but they're veeery laid back ;;especially compared to the middle east

B:humhum

(2sec)

A: just a different life style I guess but 19:13

B: yeah.;; 19:Malasia is interesting 
A:humhum

B:pretty conservative

A:yeah they are they are very conservative and I like they are sort of assimilation, you can actually--the term of "Malay" literally means, umm, speaker;;; I mean it doesn't like--how do you say, like--to become Malay, you have to speak Malay, and like--

(19:38 Furukawa came in) 


\section{APPENDIX H: Japanese Small Talk Data [J-1]}

\section{A: Hiroshi \& B: Shin}

5:58-6:53 Topic 2 (55sec)

A: はじめまして

B: はじめまして

A: 今、えつと。。

$\mathrm{B}:$ 今、早稲田から留学して、、

A: あっ早稲田。はいはいはい

B: 二週間前ぐらいに来ました。

A: あ一じやああれですね、あの T N P ?

B: はい

A: あ一あ :

A: いかがですか?

B: という一種の?

A: あ一いや個人で、自分で、あの、えっといちもう一年半ぐらいいるんですけど、

B: おー

$\mathrm{A}:$ 一年半ぐらい前に自分で

B: あっ普通に? 留学して?

A: そうそうそうそう 申し込んで 自分で

B: あっあっあっ あ一

A: 普通にP S Uのランゲージの あのあのクラスとってます。

B: あっつそれ名前なんていうんですっけ?

A: ひろしです。名前は?

B: 長谷川しんです。しんです。

A: あっ名前って言うのは?

B: あっランゲージ

A: I L P

B: I L P

$6: 48$

B: I L P のひとたまに会います。

A: うん。うーーん。

B: この前コーヒーアワーに行ったら、

A: う一ん。6:53

(1) (3 秒)

6:56-7:53 Topic 2 (57sec)

$\mathrm{B}:$ 基本ランゲージのとこってなんかキャンパスの中です?

A: そうそうそうそう

B: 僕もなんか交換留学じやないんで普通になんか英語の授業となんか

A: レギュラーと?

B: レギュラーちよっと；でなんか英語の授業プログラムで来てる人だけでやっているで

A: うんううんうんうんうん そっか

(2 秒)

B: 一年半いるんでもうペラペラ? 

A: 全然
B: まだ二週間なんで全然しゃべれないですもん
A: う一ん、まっ自分は、これぐらい、来る前に、これぐらいできたらいいなって思うと こまでは達してるんだけど着たらきたで
B: まだまだもつと上?
A: 全然足りない、うん、やっぱり。。。
B: 今どこに住んでるんですか?
A: 今、あのセイフエーわかりますか?
B: あっはい。

\section{A: あそこの目の前のアパートに住んでます \\ B: おー7:52 \\ (2) (6 秒)}

7:58-8:53 Topic 4 (55sec)

B:やっぱアパートきれいですか?

A: アパートきれいですよ。

B: 寮なんですけど、めっちゃ污いんですよ。

A: オンディーン?

B: オンディーンっす。

A: オンディーン污いよね

B: 匂いくさいし(うーん) 虫出てくるし

\section{(2 秒)}

A: そっかそっか

\section{(2 秒)}

A: なんか移る人もいますよね、結構。

B: はい。意外とルームメイトはいい人だったんで、

A: うんうんうんうん

B: まっ移って次のルームメイトとうまくいくか分からないんで。

A: うんうんうんうん

B: まっなんかこれでいいかなっと思うんすけど。

A: うんエプラーが結構きれいですけどね。

B: あっそうなんすか。

A: うん、できたばっかりで

B: あ一、とも友達がブルーベルにすんでて、

A: うんうん

$\mathrm{B}:$ ブルーベルなんかこの春から

A: うんそうそうそうそう空いたね〜。前までずっとしまってて一年ぐらい。

B: ちょ一きれいなんで

A: うん

B: 最近そこにいる時間の方が長いかな (笑)

\section{A: う一ん。そっか。8:53}




\section{(3) (7 秒)}

9:01-10:00 Topics 2\&4 (59sec: topic2 (32sec), topic 4 (27sec))

B:まだ着たばっかりなんでポートランドもよくよく わからないんで。。

A: ね、すみやすいですよ。 まっちょっと雨の時期が

B: あっはい(笑) ほんとそれっすよね。

A: でもまだここ最近 5 ましなほう。。。でもこのシーズンは今シーズンはわりと雨少な い方だと思う。

B: そうなんですか?

A: うん

B: なんかきた時めっちゃ晴れてて

A: うんうんうんうん

B: なんかもうこんな春だったんだ晴れるのかなーと思ったらちょっとしたら

A: うんまた雨降って； ; う一ん

\section{(2 秒)}

\section{A: 二週間か〜 (独り言) 9:34}

B: でもいるの 12 月ぐらいまでしかいないんです。

A：うんうん、でも延ばせますよね?一応延ばそうと思えば。

B: あっはい。

A: うんうん

B: でもなんか今もう三年で、

A: うん

B: 帰ったら就活しないといけないんで、でなんかじゅう 12 月から

A: うんうんうんうん

B: なんでちょうど。。。って感じ

A: 延ばしてる暇ないのか。

B:はい?

A: 延ばしている暇がない

B: そう、そうっすね $10: 00$

(4)(3 秒)

A: うーーーん

(2 秒)

A: そうですよね。(独り言のように小さい声で) 10 : 05

B: NA

(5)(3 秒)

10:08-10:12 Topics 5 (4sec)

B: $10: 08$ 本当はもっと長くいたいんですけどね。

A: う一ーん。

B: 8 ケ月って短いですよ

A: うん

6)(3 秒) 


\section{0:15-11:19 Topics 5 (1m 04sec)}

A: そっかー(独り言)

B: えつ結構もうこつちであの現地の人と仲良くなってます?

A: うーーん。それこそ親友みたいになるには。。。なかなか難しいね。

B: ですよね

A: やっぽ言葉の壁もあるし、ただまあ、いろいろそのアメリカ人のネットワークを広げ れば、

B: ふふん

A: まあ、親友までにならなくても

B: 女一

A: う一ーん。

A: しょっちゅういろんな種類の人とまあ遊べば; うん

B: 来てるのはもう早稲田の学生でいっぱい来ちゃってるんで

A: うんうんうん

B: 結構それも中でもからんじゃうんすよ

A: うんうんうん

B: なかなか英語を話せない

A: うんうんうんうんそうだよね

B: なかなか難しい

A: まあでも早稲田のコミュニティは結構強いからいろんなネイティブのね、現地の学生 とか

B: あ一

A: 関わりがあるから ; まあどっぷりつかるのはあれだけど

B: あ一

A: 多少はなんかかかわる分には

B: あ一そうですね

A: うん 11:19

(7)(3 秒)

A: そうだよねえ (独り言)

B: NA

(8)(4 秒)

A: 一年か (独り言)

B: NA

(9)(4 秒)

11:31-13:41 Topics 5 (2m 10sec)

A: でもしゃべれるようにはなると思うな; 思います保障

B: はははは (笑)

$\mathrm{A}:$ 生活に支障がない程度の英語ぐらいは;;

B: あ一 
A: うん

A: ただいまだに満足してないな

B: あ一

A: うん

A: なんか半年；；過ぎたぐらいから

B:はい

A: ちょつとずつこういちいち頭の中で文法考えなくても

B: あ一なんかみんな半年たつと変わるつていいますね。

A: そうフレーズで覚えていくからフレーズがどんどんしゃべれるようになり始めてただ なんかそこに甘えちやうのかな? 新しいことを取り入れようとしなくなって

B: ほー

A: だから途中でまたこう、なんだろう、いろんなことを取り入れるように話そうと努力 するんだけど、

B: はい

A: そうだな。またそのさらに半年、だからまたちょうど丸一年ぐらいでまたちよっとち よこっと伸びて、で、今ちょっと伸び悩み中。なんかあんまり前のレベルからなんにも 変わってない気がして。

B: でもリスニングとかは? 普通に聞き取れます?

A: 授業は今こうやってじっくり聞かなくても

B: あ一今なんちょっと気を奶をもうなんていっているか分からなくなっちゃって

A: うんうんうんうん

B: あとなんかけっこう留学生同士で話してるのはいいんですけど、ネイティブの人だと (うんうんうんうん) 話しているときに何言ってるかわかんなかったりするんですよ。 A: うんうんうんうんそうだよね。しかも人によってすっごい話し方が早い人もいるし、 そういう人には全くついていけないから、

B: そうですよね。

A: だからもう本当に分からないときは本当にききにいかないと宿題もできないし、

B: あ一あー

A: オフィスアワーとかに顔出して

B: あ一

A: もう一回確認したりとか。13:41

B: NA

(10)(5 秒)

A: 13:47 うーーん (フィラーなんか音)

\section{B: NA}

\section{(11)(4 秒)}

13:51-14:29 Topic 5 (38sec)

$\mathrm{A}:$ で今一応こっちの大学院にいこうかなって考え中で

B: あっそうなんすか? 
A: うん。なかなか；でも T O E F L もとんなきやいけないし

B: あ一あ

A: GMATっていう法律とか

B: あ一聞いたことある

A: 数学とかはいってる、ネイティブでもなかなか点が取れないみたいなやつで

B: えつ英語で普通の勉強のやつをするんですか?

A: そうです。そうです。うーん。

$\mathrm{B}$ : さついすね。

A: まあ文法どうこうの問題じゃなくて

B: 大学院ってT O E F L 100 以上ないといけないんですよ补?

A: まっ、院によるんですけど、P S Uはまだゆるくて

B: はい

A: 80 ぐらいで大丈夫です。

B: あーそうなんですか

A: P S Uは、大学院は、14 : 29

(12)(5 秒)

14:35-14:39 Topic 2 (4sec)

A: ただ入ってからそうなるとたぶんつらいと思う。100ぐらい取れてないと。

B: まあそうですよね。

A: やっぱ 100 ぐらい取れてないと

(13)(17 秒)

14:56-

B:なんか趣味とかなんかあるんですか?

A:趣味ですか?

B:こっちでなんかしてたりします?

A:こっちでは、でもやっぱり日本人、遊ぶときは日本人と結構遊んでますよ。

B:あ一はい。

A:うん、なんかボーリング行ったり

B:あーしたのとこっすか?

A:スノボ行ったり

B:あースノボって近いんすか?

A:マウントフットなので車で一時間半ぐらい、

B:あ一近いっすね。

15:24古川ノック 


\section{APPENDIX I: Japanese Small Talk Data [J-2]}

\section{A: Shinji \& B: Tadashi}

\section{7:25-9:10 Topic 2(1m55sec)}

B: はじめまして、野上っていいます。

A: PSU の学生ですか?

B: いや、僕 ILP なんで、

A: あーー なるほど、

B: え、P S U?

A: P S U

$\mathrm{B}:$ レギュラー?

A: いや、僕一年間の交換留学で、

B: えつ早稲田の方で?

A: はい、そうです。

B: あつやっぱ早稲田の方いますよね、ほんとに。

A: いや、いや、いやって

A: えっいつ来られたんですか?こっちは。

B: 僕今半年になります。

A: じゃあもし一緒のタイミングっすね、僕も去年 9 月きたんで、

B: あっそうなんすか。

A: あ

B: で一回も会わなかったすね(笑い)

A: そうですね、

B: あはあは

A: 回りまわって今日始めて

$\mathrm{B}:$ そうっすね

B: ぼくずっと前のタームまでホームスティ、ホームステイしてて

A: う一ん、

B: 終わったらすぐ帰ったりして

A: あ一それじや会わない寸ね。

B: えっどこに住んでいらっしゃるんですか。

A: 寮ですね。あのモンゴメリーという

B: あっモンゴメリーに住んでいらっしゃるんですか?

A: あっ知ってます?

B: あっ僕ブルーメイルに住んでいるんで、

A: あ一、一番いいとこじやないっすか。

B: いや、新しくなっていいですね

A: えっあそこルームシェアでしたっけ?

B: シェアとシングルがありますね、まっでもシングルは高いんで、

A: ルームシェア?

B: ルームシェアで。

A: 何人ぐらいですか? 四人?

B: いやっ、二人。

A: あ一じゃあちょうど良いですね。

B: 4 人とかあるんすか 
A: 4 人は： : なんか女のユニバーシティポイントっていう

B: あっポイント? ポイントははい、でもあれハウジングじゃないじゃないですか

A: ああ。P S Uと関係ないんですかね?

B: だからあれ、12 ケ月契約でしかとれなくて、僕もあそこ移ろうかなって思ったんで

すけじ、12 ヶ月契約しかなくて、どうせ半年で帰るし

A: あ一

B: 移れなくて、でブルーメイル。

A: あつじやあ 8 月ごろ?

B: そうですね、8月ごろか 9 月の頭か

A: あっじやあ吉田とか知ってます?

B: ヨッシーとか? ヨッシーすか?あっはい。あっまあ仲良くはしていますね。

A: あいつも同じプログラムですよね?

B: もう、完璧に同じです。

(1)(4 秒)

9:14-10:09 Topic 1 (55sec)

A: おいしいですねチャーハン

B: 久しぶりにチャーハン食べた笑。

A: そうですね

$\mathrm{B}$ : 全然おなか減ってない。。

A: ふふ笑 僕もさっき食べたんですけじね。。

(2 秒)

B: ほんと冷たいっすよ。(カップケーキ)

A: すげえでかいな (ピザ?)

B：昨日の晚飯ピザだったんで、、、

A: あはは(笑)

B: 家にもまだピザ残ってる。。。

A: 今日はいいかな?って

B:あつこれ全部もう録音されてるんで。

A: えつ?

B:ははは(笑)

(2 秒)

A:テーマなんでしたっけ?

$\mathrm{B}:$ なか力本のアメリカの生活について聞きたい。

A: あ一

(omitted lines: continued talked about the study)

$\mathrm{B}:$ これ聞きながらこれ聞いているとき笑っていると思う (笑)

A: あは笑

A: あ一しまったこっち食べればよかった 10 : 09

B: NA

(2)(6 秒)

10:17-10:48 Topic 2\&4 (31sec: topic2 (22sec), topic4 (9sec))

A: I L P だったら奥村里美さんとか知ってますか 
B:あっ里美さん?はいまあ知ってる程度です。俺ぜんぜんそういう輪にはいってなくて、 ずっと;; いやなんかみんなこの辺に住んでいるじやないですか?みんなでだから飲ん でたりしているけじ、そういう行く機会なくて。知ってる程度。

A: あ一

(2 秒)

A: (10:39) 里美さんて英語うまいんですか?

B: えっでも結構上の方じやないですか?もう。

A: えー

B: もう、レギュラー?

A: もうレギュラー、レギュラーにトランスファーしましたよね。

B: ですよね。

A: やるなあいつ。

B: NA

(3) (4 秒)

10:54-11:35 Topic 2 (41sec)

B: うん、まあ すごいな早稲田 (独り言?)

B: えっブルーメイルにも早稲田いっぱい

A: あ一そう

B: いますね。

$\mathrm{A}:$ そう、新しく三週間前から来たやつが。。

B: あ一なんか来てましたね。あの一来ててみんな。：：家の階に

A: うあん

B: 四五人いるんですよ、日本人が。

A: んふふふふ。。。多(い)。いやほとんど早稲田ですか?

B: もちろん早稲田です。

A: ふーん。いいなブルーメイル

B: まあまあまあ

A: えつよくなんか廊下であったりします?

B: よくーー、まあまあ会います社、そりやあ。。。でも「どうも」ぐらい。

A: ははは(笑い)

(2 秒)

A: まあそうなりますよね。ぼくも寮ですけど、「ハイ」みたいな感じですね。

B: そうっすね。

(4)(10 秒)

$11: 45-12: 01$ Topic 1 (16sec)

A: 今日どのくらいこのインタビューとかかかるんですかね。30 分っていわれました?

B: そんなにかかるんですか?

A: いやあ。。

B: いや別に何分でもいいっすけど (笑)

A: はは (笑)

B: まっ:: まっ一時間もかからないんじやないですか?

A: そうだね。

(5)(4 秒)

A:12 : 05 あーのど渴いてきた。(独り言) 


\section{B: NA}

\section{(6) (4 秒)}

A: 12:11 こんな教室あったんですね?クレーマーに

B: 全く知らなかったです。OOな教室

A: 12:18 あんまこないんでクレーマー

B: 俺も授業ないです。

A: $12: 24$ (バイブ)電話だ。

電話にです。英語

(A answer the phone.....)

(7)(Silence after A hang up the phone...)

14:28-15:42 Topic $2 \& 4 \& 2$ (1m14sec: topic 2(28sec), topic4 (7sec), topic2 (39sec))

B:14:28 あつ下の名前きてもいいですか?

A: しんじです。しんって呼んでください。

B: あっしんさんはい、了解です。

(2 秒)

B: えつ今おいくつですか?

A: 今、25 です。

B: あ一全然ね、はいすいません。

$\mathrm{A}:$ (笑)えつ何歳ですか?

B: 僕まだ二十歳なんで。(笑) もうちょっとで 21 になるんですけど、

A: おーいつですか? 5 月ですか?

B: 5 月ですね。

A：おーそりや誕生日誕生会しないと

B: はは (笑)

$\mathrm{A}:$ バースディパーティ

(2 秒)

B: やっと酒のめるようになるんです (笑)14 : 58

A: 確かに。今今まで辛かったでしょ。

B: そうですね、やばいっすね。。家に持って帰れるんで。。

(2 秒)

A: 15:05 あっそかヨッシーと同じ年なんだね。

B: そうですね。そのなんかきた時から、オリエンテーションかなんか

A: ふーーん

B: ずっと

(2 秒)

A: 15:26 おれあいつんちで飲んでるよ。 近くのアパートすんですから。。

B:なんかアレックス(うんうん)となんかシェアしてるって。

A:ああーアレックス知ってるの?

B:いや、え、あの一知ってるだけ、僕が一方的に知ってるんで。

A:あははは(笑) そっかそっか。15:42

\section{B: NA}

(8)(8 秒)

A: 15:50 うまいな(独り言)

B: NA 


\section{(9)(8 秒)}

B: 15:58 はあーー(ため息)

A: NA

(10)(19 秒)

16:18-17:12 Topic 2(54sec)

B:えっレギュラーのクラスってやっば難いっすか?

A: むずいねー やっぱ

B: もう全部レギュラーのとってるんすか?

A: いやっ、

B: えっといまいち分からないんですよ悋。。プログラムが。

A: 僕らは二つ英語をとってもう一つ、あっあと二つですね。あと二つレギュラーって感

じ。英語半分レギュラー半分で、行ったりきたりしてます。

$\mathrm{B}:$ 約一年?

A: えっ I E L P は全部英語ですか?

B: うん、も一英語しかないです。でもなんかレベル 5 終わると、1 から 5 まであって 5 が終わるとレギュラーの取れるんですよ。

A:あー

B: まだでもたぶん次はレギュラーだと思うんすけど。

A: おっ!はれて夏から?

B:いや、夏タームって休み中だしなーとか思いながら、

A: そうっすよ悋。7 月 8 月遊ぶの?

B: そうっすね。

A: 休みだしね。17 : 12

(11)(9 秒)

A: 17 : 21 ちえさん遅いっすね。

B: NA

(12)(34 秒)

17:55-18:04 Topic 1 (9sec)

B: 17 : 55 事前に質問聞いとけばよかったと思って。

A: たしかに。 。

B: なんかいきなり聞かれても

A: なに答えていいかわかんないっすよね。 (13)(17 秒)

18:21-18:30 Topic 2(9sec)

B: えっジョージとかミッキーとかわかります？

A: あ一全然わかりますよ

B: あ一あいつらと仲良くなって、

A: う一ーん。わかっちやいましたね。

B: うん、わかりましたね。

A:さみしーすよ。

B: NA

(14)(12 秒)

Silence continue

$18: 44$ 古川ノック 


\section{APPENDIX J: Japanese Small Talk Data [J-3]}

\section{A: Jiro \& B: Tomoki}

5:09- 5:35 Topic 2\&1 (26sec: topic2 (20sec), topic1 (6sec))

A: 早稲田すか?

B: はい、早稲田です。

A: T N Pっすか?

B: はい、 T N Pっす。三週間前ぐらいに

A: えつ?

B: あっ三週間ぐらいに

A: あ一三週間前ぐらい

$\mathrm{B}:$ こっちにきて、本当にごめんなさい。

A: どこで、どこで知り合ったの? 5:20

B: あっコーヒーアワー。先週の水曜日。

A: あ一一あっこれおいしいですよ。

B: あっいただいていいっすか?

A: 作ってきたらしい。(つぶやくように。。)

B:NA

(1) (8 秒)

5:43- 6:09 Topic 1 (26sec)

A:なれました?

B:慣れました。だいぶ。。

A:授業は； ; 今英語となんだっけ

B:選択でジャパンナイトって言う日本の文化とアメリカの文化をミックスされた映画み たいのを

A:ふーん

(2)(5 秒)

6:14- 6:43 Topic 1 (30sec)

B: ロハスってことは、6月ぐらいにもう帰っちゃうんですよね?

A: そうですね、もう春学期が ; ; 6 月の半ばにおわったらその後は。

B: 学部はどこですか?

A: 僕は教育です。

B: あー

A: どこです?

$B$ : 社会学です。

A: 社学っすか。

$\mathrm{B}:$ 今新四年ですか?

A：うん、今新四年 日本にいれば、、、ですけどね。何年生ですか?

B: 今新三年です。

A: あ一新三年ですか

(3)(4 秒)

6:47- 8:15 Topic $2 \& 1$ (1m28sec: topic2 (1m12sec), topic1 (16sec))

A: じゃあゼミは?

B: ; ; ; ; 入ってないという 

A: 入ってない！ こい?
B: いや、こいではない。
A：いろいろあった?ははは（笑）
B: まあちょっといろいろありました。
A：ははは（笑）
$\mathrm{B}:$ ははは（笑）
(2 秒)

$\mathrm{B}:$ 帰つて就活?

A:帰って、うん；今年の； ;

B: あっなんか四月からになるみたいですね。

$\mathrm{A}:$ ま 16 年卒からなんで。

B: ; ; あっ 16 年卒の。。

A: 僕 15 年卒なんで 7:20

B: あーっじゃ

$\mathrm{A}$ : 留年しないっすか?

$\mathrm{B}$ : 留年で卒業です。

A: じゃあ 12 月です。 $7: 28$

B: あっそうなんっすか

A: 僕らの一こ下からみたいですよ。

B: あっそうなんですか

A: 僕留年するんで一年。 5 年生で卒業して 2015 年卒業。； ; まだ正式に ; ; 発表があ ったわけじゃないからなんともいえないこないだ；；；日か 5 日ぐらい前にじきゅう 時間、間に合わないから 16 年卒から四月

$\mathrm{B}: 4$ 月スタート?

A: 3 月スタート。 $7: 59$

B: あ一めちやくちゃおいしいっすね。これ

A:ふふ。；；；葉っぱ好きすか?

B: あっはい、食べれます。あっでも:パっパクチーこっち多くないすか?

A: パクチー多いっすよね。

B: あれ、きらいっす。

\section{A: 東南アジア系の料理多いから}

(4)( 7 秒)

8:22- 9:39 Topic $2 \& 1$ (1m17sec: topic2: $(1 \mathrm{~m})$, topic1(17sec))

A: あっお名前は?

$\mathrm{B}:$ 上原です

$\mathrm{A}:$ 上原?

$\mathrm{B}:$ 上原智樹です

$\mathrm{A}$ : 上原上原。

$\mathrm{B}:$ タイガさん?

A: タイガ?

B: あれタイガさんじやなかった。 
A: ははは (笑) たいがは山田、山田たいがです別の

B: あっ朝野?なんて?

A: じろうです。

B: あっじろうさん。

A:んふん(せきばらい)

(2sec)

A: サークルはなんですか?

B: 野球サークルと出版系のサークルです。

A: 野球どこですか。

$\mathrm{B}:$ グラキャン。

A: グラキャンっすか?

B: あっ知ってますか?

$\mathrm{A}$ : 桜坂とか知ってます?

B: ぼく幽霊部員なんでちょっと (笑)

A: ははははは(笑) なるほど。

B: ちょっとわかんない。。

$\mathrm{A}:$ 一個上のぼくの同級生が

B: あっ教育の人ですか?

$\mathrm{A}$ : 教育の; ; ;学一年の。

B: あっこれパクチーすね。9:22-

A: ははははは (笑)

$\mathrm{B}:$ パクチーはいってた。

A: ダメですね。じやあね。

B: あ一おいしいです。教育って新四年の人ですか?

A: 新四年

B: ふーん、顔見れば多分分かると思うんすけど 39

A: NA

(5)(3 秒)

9:43- 10:22 Topic 2 (39sec)

$\mathrm{AB}$ : ? ? ? ?

A: ははははは (笑)

A: えっ出版系っていうのは? 9:46

B: キュウっていうCUEっていう

A: うーーん

B: フリーペーパーを作っている 小さいサークルで

A: 最近できたんすか?

B: いや、そんなことはないっすね

A: ヘーーそっちがメインっすか?

B: うんそうです。

B: 何サークルに入ってるんですか?

A: ぼくほけんです 
B:ふーんふーんふーんふーんふーん

A: 誰かいます?じゃあ?

B: ほけんは知らないっすね。規模がでかいくらいしかしらない。(笑)

A: ははは (笑)

\section{A: 規模はまたでっかくなたな。(独り言)}

\section{B: N A}

\section{(6) (4 秒)}

A: せきばらい

B: N A

(7)(7 秒)

10:33-11:14 Topic 2 (41sec)

B: ほけんかわいい人多いっすよね?

A: 偏見じゃないっすか?なんか人数多いから。(笑)

B: あはは (笑) 大学際のときとか

A: なんかいました。

$\mathrm{B}$ : 客引きじゃないっすけど

A: あはははは (笑)

B: とにかくかわいいんですよ。なんか

A: そー?そーでした? (笑)

B: かわいい。

A: それ、運がよかったんじやないっすか?

B: ほんとっすか?あはははは (笑)

A: あはははは (笑) 55

(2 秒)

B: ほけんフリーペーパーとか作ってます?

A: フリーペーパーは年一で作ってますね、広告に関することでしたら ; ; こんなこんな ないすか?

B: しらないっす

A: わかんないっすか? グラキャン。

(8)(5 秒)

A:ひえー(独り言)

B: N A

\section{(9)(16 秒)}

11:35- 12:11 Topic 4 (36sec)

B: オンディーンですか?

A: ぼく、オンディーンです。

B: 何階ですか?

A: あっぼく七階です。11: 39

B: ぶーん,

A: あっなんだっけ、しず、しずみ、しずえ?

B: しずかさん? 
A: しず、しずか? C N P のなんちやらしずかなんちゃらしずかてのが隣の隣です。

B: あ一

(2 秒)

B: 名前は; ; 聞いたことが。。

A: オンディーンですか?

B: オンディーンです。12 階です

A: 10 階?

B: 12 階です

B: 木村さん?

A: あー

(10)(3 秒)

11:14- 12:28 Topic 5(14sec)

B: 木村さんとしずかさんって付き合ってるんですか?

A: へえ! ? 12:18

$\mathrm{B}:$ つあってないっすか?いや一いつも一緒にいるんで、仲いいなーと

A: そんなことは全くないきがする。

B: ふーん

A: まっ木村は木村で彼女がいるんじゃないかな。

B: あっそうなんすか。

レコード発見?

A: はは、(笑)

B: いやちょっとビックリしました。

(11)Silence after they found the recoder...(4 秒)

12:41-13:28 Topic 5(47sec)

A: ルームメイトは?

B:います

A: 何人?

B: アメリカ人です

A: アメリカ人 へえー。

B: 会話が全くないっす。

$\mathrm{A}$ : 会話特にない? (笑) 仲悪いんすか?

B: いや悪くはないですけど。。。； ; なかかつもこうやってテレビ見てるかパソコン してるベットの上で、一日中部屋の中にいて、

$\mathrm{A}:$ へ(笑) 授業いかないんすか?

B: みたことないっすね。(笑) ぼく朝が早いんで、8 時 50 分ぐらい部屋でて

A: う一ん

$\mathrm{B}:$ 出るときは部屋にいるんですよ。

A: 起きてるんっすか?

B:で、あっはい、いろいろ終わって；；4 時ぐらいに帰っても部屋にいる。それからず っと部屋にいるんで。 
A: あはは (笑)

B: 僕がいない間にいってるのかもしれないですけじ (笑)、

A: あっ帰らないんですか?

B: 帰んないことが多いです。

A: ヘー

(12) ( 7 秒)

13:35- 14:19 Topic 5(44sec)

B: ルームメイト、今シングルですか?

A: ルームメイトいます。マイケルっていう。

$\mathrm{B}$ : 仲良いですか?

A: 仲、まあまあ、まあいい方いい方じゃじゃないですかね。

B: ふーん

A: うん。

B: いっしょにご飯食べに行こうよとかなるんですか？

A: ごくたまに

B: あっいいっすねえ。

$\mathrm{A}$ : でも基本的に彼は部屋部屋にいたがる、ゲームがしたい

B: あ一 じゃあタイプが似ているかもしれない。笑

A: あは (笑)； ; 生活リズムはでも、今はかれはもう

B: はや

A: 明け方から昼にかけて

B:ふーん、じゃ夜遊びに行っちゃうんですか?

A:いや、ゲームしてる。

B: あは (笑)

A: へえへへ(笑)

(2 秒)

A: なんかルームメイトも ; ; ; みんなそれぞれ、なんかなんだかんだでうまくやって はいるけど、お互いにいろいろ不満もあるみたいですけどね。

\section{B: NA}

(13)(3 秒)

14:36-15:29 Topic 5(53sec)

B: 本当に一切会話がなかったんですけど、こないだ、めっちやはやいんですよ。寝るの。 もう 10 時か 11 時には全部電気消して寝ているんですけど。

A: お互いに?

B: いや僕は遅くて、

A: うん

B: で一時半ぐらいに夜中帰ったら珍しく起きてて、真っ暗の部屋でパソコンしてて顔だ け照らされている状態で

A: あははは (笑)

B: コワっと思って、なんで今日起きているんだろうと思って、、まあ寝る準備してたら、 いきなり話しかけてきて「アルチメットって知ってる?」ってあ一知ってるって、、今 度やろうよって。 
A: ふふふふふふふふ(笑)

B:いや、いきなりだなって思ったんすけど、仲良くなるチャンスだと思って

A: あははは (笑)

B: こないだ先週の木曜やってきました。

A: へえー あははは、ちょっと怖いですね。(笑)

B: ほほほ(笑)

A: 突然

B: でも優しいですよ

A: ふーん。

(14)(3 秒)

15:32- 15:44 Topic 5(53sec)

A: 掃除とか身の回りは?

B: 一切干渉しあわないんで。僕実際しないんで、冷蔵庫とかも問題ない。

A: あーそう

(15)(6 秒)

15:50- 15:54 Topic 5(4sec)

A: わりとおとなしい系なんだ

B: おとなしいですね

(16)(6 秒)

16:00- 16:50 Topic 5 ( $50 \mathrm{sec}$ )

B: 夜うるさくないですか? ゲームやってて。イヤフォンとかつけてつけてくます?

A: んー、たまに言わないとつけないけど、

B: あ一でも言うんですか?うるさかったら。

A: うるさかったら。よっぽどうるさかったら； ; ちょっとうるさいぐらいだったら自分 が耳栓して

B: あーあー

B: 何時ぐらいまで起きてるんすか?

A: 僕が分からないぐらいまで

B: あ一

A: 僕が寝てから。

B: えっ何時ぐらいに寝てるんっすか?

A: 大体二時三時ぐらいに寝ますけど

B: じゃあそのあとってことは、

A: 二時三時に寝るんですけど、彼はその頃にラーメンを作り始めて、

B: え一

A: ご飯食べ始める。

B: 学校行ってるんですか?

$\mathrm{A}$ : 一応いってるんですけど、授業以外はバスケをしてるか

B: ふーん

A: ゲームしてるか。 (17)(4 秒)

16:54- 17: 59 Topic $5 \& 4$ (1m 05sec: topic5(14sec), topic 4(51sec))

B: 一緒にお酒飲んだりするんですか? 
A: 以外たま； ; たまにたまに飲んでかえってききすけど、あんまり飲まないですね。そ もそも未成年だし、けっこう厳しいですからね。17:08

B: 本当に峳しいですよね。

A: 特にあの；；七階までは； ; 持ってちやいけないんですよ。僕でも

B: えっそうなんすか?

A: 僕でも

B: えっ 何でですか? じゃあ飲むのはもってのほかですか? 7 階以下でも

$\mathrm{A}$ : そう 3 階から 7 階はそのフレッシュマンのフロアドライフロアっていって。

B: なんでフレッシュマンのフロアにいるんすか?

A: ん一ん、わかんないっす。17:32

B: ^ー

A: でも部屋の配置は結構適当な感じがしますけど、留学生だからかもしれないっすけ

ど ; ; でも、3 階から 7 階はドライフロアっていって、お先持ち込み禁止だからね。

B: ヘー

A: 僕かく隠し持ってますけど。。

B: ははは (笑) 実際ばれないっすよね?

A: まあ、下手しなければですけどね。

B: ですよね、ですよね。騒がない限りはこないっすよね。

(18) (4 秒)

18:03- 18: 27 Topic4 (24sec)

A: まっ 12 階なんで問題はないはないと思うけど、; ; ルームメイトも?

B: ルームメイトも二十歳です。一緒です。

A: あ一本当はいけない

B: あっ酒のんでいるところ見たことないっす。

A: あ一飲まないんだ。

B: スイートベット共有じゃないっすか? ベルベットの中、ベルベットじやない。冷蔵庫 の中に酒がはいってるのみたことない。

A: ふーん。

(19)(3 秒)

18:30- 18:34 Topic 4 (4sec)

A: みんなこっそり飲んでますけどね。(笑)

\section{B: へ几 (笑)}

(20)(3 秒)

A: いるも自炊してるんですか。

B: う一ん。自炊。；；比較的外食は少ない方だと思うんですけど、自炊といわれる ほど自炊ではなくて。。

18 : 50 古川ノック 


\section{A: Kazu \& B: Kenji}

\section{APPENDIX K: Japanese Small Talk Data [J-4]}

3:29- 3:59 Topic 1 (30sec)

$\mathrm{A}:$ ここの学生さんですか?

B: はい、ここの、そうっす。

A: すげー(笑い)

$\mathrm{B}:$ え、ここですか?

A: いえ、早稲田のなんか留学みたいな感じで：：4 月から

B: あ一じゃあここの学生じゃない

A: はい、留学生扱いで

B: 留学です。

B: そうそうそうそう。あつ早稲田のーー。3:46

A: 寸げーな、えっなんで入ろうとしたんですか?ここの大学に。

B: いや、はいってないまだはいってない。はいってないはいってないはいってない!

A: あっあはは (笑)

B: おれも四月からきたんで、ここ

A: ふーん。

(1)(3 秒)

4:02- 3:34 Topic 2 (32sec)

A: ふーん。

$\mathrm{B}:$ 東京の人ですか?

A: はい。千葉です。

B: あ一すごいっすね。早稲田って。

A: いやいやいや。

B: いやいやいや。

B: あの何人ぐらい来てるんですか? 早稲田って

A: そのー一緒のプログラムできたのは

B: はい

A: 30 人ぐらいで

B: ふーん

A: うん

B: 普通にみんなで授業受けて

A: うーーん。で後なんか自分で好きな授業があって選べてみたいな、

B: ふーーん

A: あっそのやつは結構外国人がいて。

B: あ一

A: 普通の授業

B: あっごく大学の授業?

A: うん。

B: ヘーえ

(2)(3 秒)

4:37- 5:21 Topic 2 (44sec) 


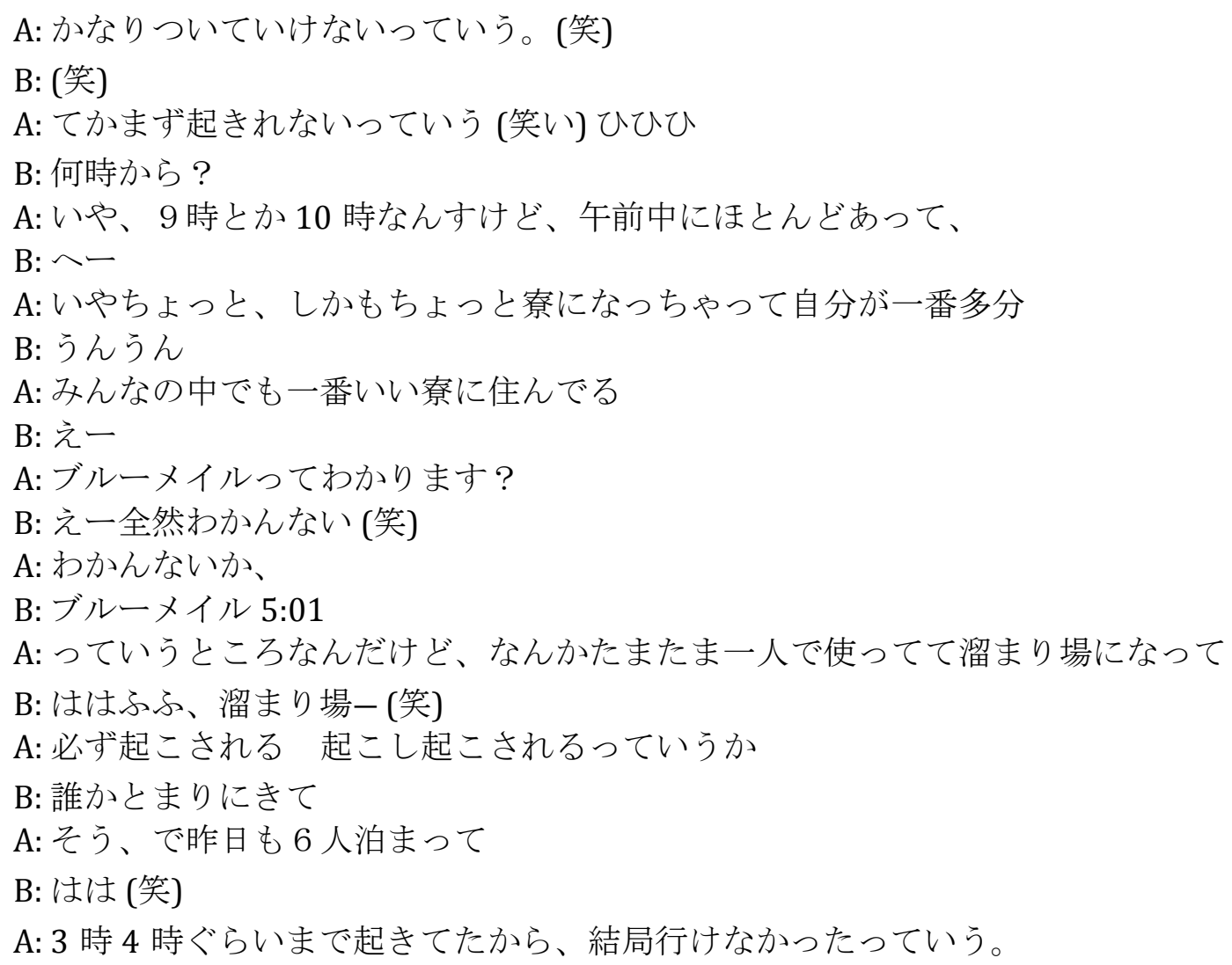
A: う一ん 


\section{B:うん(食べる音)}

(5)(5 秒)

6:02- 6:46 Topic $2 \& 4$ (44sec: topic2 (28sec), topic4 (16sec))

A: チョー無難なとこ選びましたよ。

B:あっはは(笑い)

A: そここはなんかここは結構その早稲田の中でも毎年結構来るから、、4月と 9 月にそ れぞれ別のプログラムがあって

B:おお一寸っ(っげ)は一

A: それで一年間 ; ; ; 勉強するんだけど、毎回それが 30 人

B:ふんふん

A: 20 人ぐらい来ててー

B: あ一春学期で

A: うん

$\mathrm{B}:$ それぞれ一年ずつサポートするの?

A: うん、んだからめちゃくちゃ早稲田の人が多いかも 6:30

B: あんま日本人みーひんけど、

$\mathrm{A}:$ こ?ですか?

B: なんかからからか絡んでないからかもせん。なんか

A: あ一

B: あっまず、こいつみても韓国人か中国人かってみんなそれわかるやんっていうけど、

A: うんうん

B:ほんまに

A: ふふ(笑い)

B:やばい俺がっつりくってる。(笑い)

A: はは(笑い)

(6)(3 秒)

6:49- 6:54 Topic 4 (5sec)

B:uga $¥$

A: が $\mathrm{k}$ (start taking at the same time)

B:おれ、今年大学卒業して

A: うん

B:留学

A: ヘーー

(7) ( 4 秒)

6:58 -7:08 Topic 4 (10sec)

A: それ自分でなんかこう。。

B:うん、自分で手続きとかしてアプリケーション出して

A: へーすげえ ; ; えっじゃ完全に一人できた感じですか

B:うん、完全に個人

A: すげえ! !

8(3 秒)

7:11-8:02 Topic 2 (51sec) 


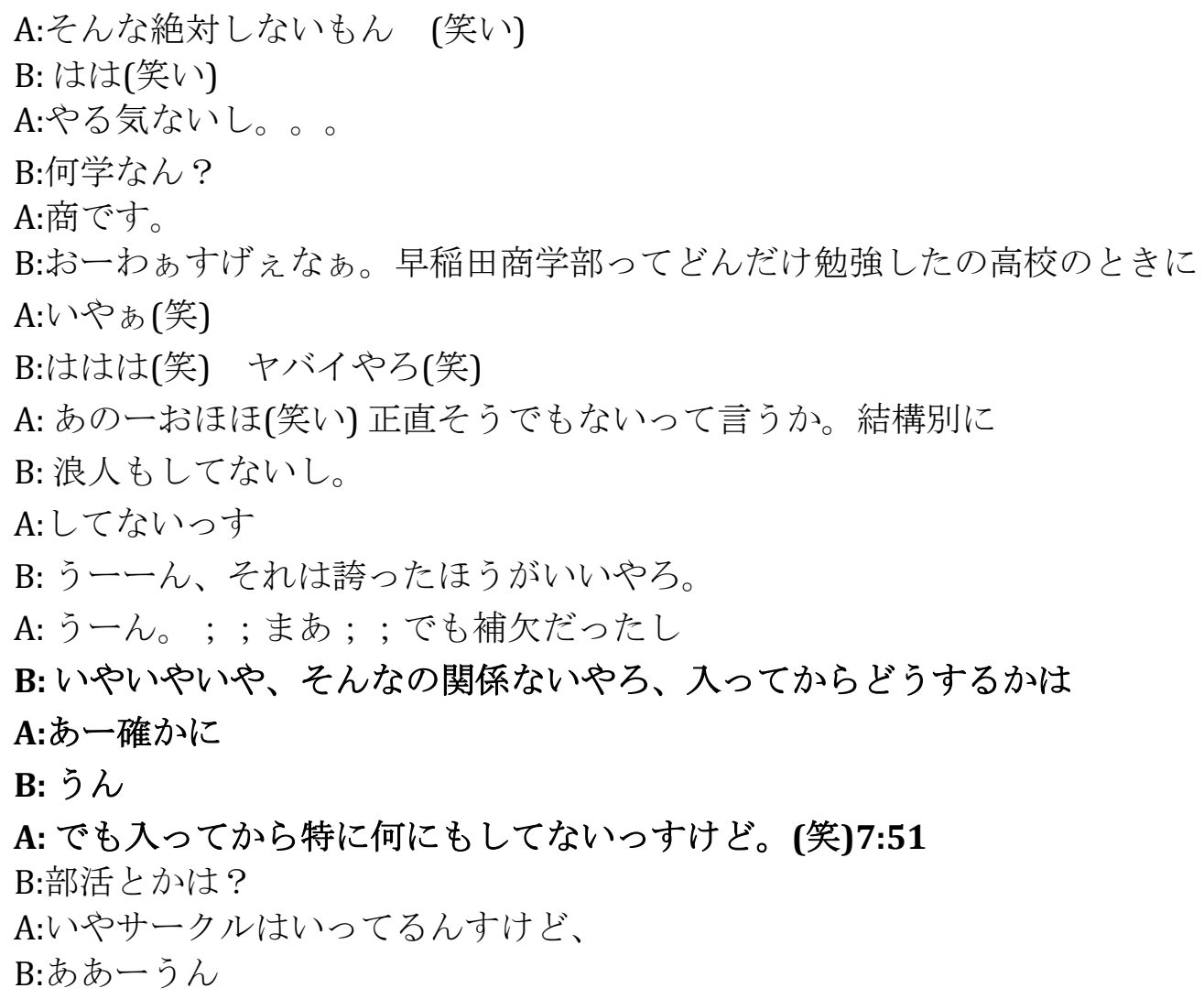


B: セレクションとかプロやんかな

A:でも早稲田の； ; あれはサッカー部は毎年何人かは

$\mathrm{B}:$ プロ?

A:プロでてるらしい。。それぐらいのレベルですね

$\mathrm{B}:$ え 野球とか有名やけどな?

A: うん

B:ピッチャーとか。

(10)(7 秒)

9:15-9: 58 Topic 2 (43sec)

$\mathrm{B}:$ こってなんやったっけアパートの名前。

$\mathrm{A}:$ ブルーメイル

$\mathrm{B}:$ ブルーメイル? そこってキャンパスの?

A:あ一(え) どーどーどーむ

B: どこが近い? なんか施設? 図書館とか?

A:図書館

B:近い?

A:まあまあ近い；；えっと；；ブラッツ、マッツ

B:モントゴメリー?

A: あっモントゴメリー近い。

B:え一

A: どこに住んでます?

B:おれブルー、ちやうちゃうちやう(笑)あのブロードウェイ。

A:あーブロードウェイ、ブロードウェイか。

B:たぶん引つ越すけど(9：48) ちょっと安いところに(笑)

A:ほんほんほん。

B: ; ; モントゴメリーにするかパークウェイとか

A:あー

$\mathrm{B}:$ 考えてるけじ

B: 今二人部屋やから

A: N A

(11)(3 秒)

10:01-10:13 Topic 4 (12sec)

二人部屋どうですか? $10: 01$

B:いや、普通にいいよ。結構いい感じの人。

A:へ—

B:うん、まっでも相手によるなーでも

\section{A:あ一そりやあ}

B:ふつうに

(12)(4 秒) 
10:17-11:06 Topic 4 (49sec)

A:あんまり友達呼べなくなるのもやだなーって。

B:うんうんうん 一人だけなのそのアパートは?

A: いや、寮っす。

B: あっそう寮で、ブルーメイル。

A: いや一応二人部屋なんすけど ; ; なんか俺二人部屋で申請してたらなんか一人部屋に なったっていう。

B: まじで?

$\mathrm{A}:$ 二人部屋の料金で一人で使ってるっていう

B: おーええん。ちょっと寂しい?でもいっぱいくるんやろ

A: あ一普通に毎日、日本人が

B: 日本人かよ(笑)

A: あはあは(笑) ; ; ; だって自分の友達しかこないんすもん。同じ留学プログラムでき た。

B: なんか外人と絡んだりとかはせーへん?

A: あっその留学プログラムできたときにそのなんか僕らを支援してくれる人たち団体が いてその人とたちをよんだりします。

B:そーなんや

A:その人は

B:うんうんうん

A:結構英語ふ

B:うんうんうん

A:普通に話せる人だから。 (13) (4 秒)

11:10-11:13 Topic 4 (3sec)

A:だから今んとこ英語はなしているのその人たちかな。

B:うんうんうん

(14)(5 秒)

11:18-12:33 Topic $5 \& 4$ (1m15sec: topic5(46sec), topic4(29sec))

A:なんかほんと何しに留学しに来たんだろうっていう、はは(笑)

B:まじで?

$\mathrm{A}: 今$ 今んこの生活だと(笑)

B:まっでもいっておれも四月から来たから

A: あ一

B:そのなまあまあ徐々にじゃね?

A: あ一このままではいけないなあとか

B:あ一思ってる? 俺一回学生のときに一ヶ月間

A:あー

B:フィジーってわかる? 
A: あー
B: オーストラリアとかニュージーランドとか行って

A: ヘー

B:留学したくて、でも金ためなあかんしなって

A: あ一

B:でもとりあえず一回トライしたいと思って

A: う一

B: まずはっと思って、みんなあまり行かんとこにいったろと思って

A: う一ん絶対ない

B:フィジーやいかんやろ(笑) ?まずチョイスせいへんやん、

A: うん

B: しかも安いし

A: ヘー

B: それでいって；；そのころよりは；；なんかさらに英語力とか磨いて、仕事に直結せ いへんは。

A: うーんすげえ

(2 秒)

A: へー

B:でもしょっぱながアメリカチョイス?

A:いやっていうかなんか TOEFL の

B: う一ん

A:点数でなんかあがるじゃないですか。

$\mathrm{B}:$ トートフル?

A: あれの点数的でいえばアメリカが平均的に低かったんです。

$\mathrm{B}:$ ヘイギリスとかもつと高い?

A: イギリスは全然高いですよ、イギリスとかカナダは

B:あっそっか。

(2 秒)

A: まっだから自然とここになっちやったって

B: う一ん

(15)(3 秒)

12:36-12:56 Topic 2 (20sec)

B:あつじやあ授業も TOEFL の対策とか?

A: あっもうひとつある

B:ぶーん。

A: だけどなんかある程度の点数取ったらもういい、やんなくていいみたいな

$\mathrm{B}:$ 変えてくれる? 変える?そんなんじゃ?

A:いや帰るって言うか、別にその次のタームから； ; あ一なんか 普通の授業

B:あーそいうことか参加できるってことか。 


\section{A:はい}

\section{(16)(6 秒)}

13:02- 13:09 Topic 2 (7sec)

B: みんなライバルみたいな感じなん？そんなわけでもない?

A: いや全然

B:わきあいあいと。

A:うん。

A: ほんとに普通に遊んでみたいな

B: NA

(17)(10 秒)

13:19-13:55 Topic 2 (36sec)

$\mathrm{B}: 今 日$ 行く?インターナショナル?

A:迷ってます

B:えっチケットは持ってんの?

A:うん、一応

B:迷ってるんや?

A:ていうかこっちでもサッカー部入ってて、

B:あーそうなんや

A:知り合いが入ってたんで、

$\mathrm{B}: ヘ ー$

A:その 9 月から来ている去年の 9 月から来ている人に知り合いがいたんでいて入れても らったんすけどちょっとそっち行こうか迷ってる。

B:あ一今日あるんや。

A: うん

B:毎日?

$\mathrm{A}:$ 月水金、プラス練習試合が土日のどっちか。結構きついっす。(笑い)

B:それ、結構部活やん。ふふふ (笑い)

A:本当に結構部活なんすよ。ふふ(笑い) ; ;

$\mathrm{B}$ :部活やん

A:だからちょっとどうしようかなと思って。

$B:$ NA

\section{(18)(5 秒)}

13:59-14:03 Topic 5 (4sec)

A: それでそのだから入ろうか入らないか見たいの迷ってて

B:うーん

(19)(4 秒)

14:07-14:45 Topic 5 (38sec)

B: 俺大学時代部活やってて

A: へー

B: 陸上だけど 

A: おー
B: だから思ったけどこっちで陸上とか思ったけど 4 年間で然え尽きた。ふふ(笑)
A: はははふふ(笑)
B: も一おっしあんなに体に鞭打ちたくないなって思って
A:あ一
B: やばい
A: いやもう完全に高校でやめようと思った
B: サッカー?
A:うん
B:う一ん
(2 秒)
A: サークルもくそよえーところで
B: うん
A: なんか；；フットサルとかやろうかな
B: あ一うんうん
A: なんだかんだやっぱ
B: NA
(2 秒)
A:はー(あくび)
$B: N A$
(20) (3 秒)
14:48 古川入室 